\title{
Three essays on debt pricing
}

Citation for published version (APA):

Mimiroglu, N. (2020). Three essays on debt pricing. [Doctoral Thesis, Maastricht University]. Maastricht University. https://doi.org/10.26481/dis.20200901nm

Document status and date:

Published: 01/01/2020

DOI:

10.26481/dis.20200901nm

Document Version:

Publisher's PDF, also known as Version of record

\section{Please check the document version of this publication:}

- A submitted manuscript is the version of the article upon submission and before peer-review. There can be important differences between the submitted version and the official published version of record.

People interested in the research are advised to contact the author for the final version of the publication, or visit the DOI to the publisher's website.

- The final author version and the galley proof are versions of the publication after peer review.

- The final published version features the final layout of the paper including the volume, issue and page numbers.

Link to publication

\footnotetext{
General rights rights.

- You may freely distribute the URL identifying the publication in the public portal. please follow below link for the End User Agreement:

www.umlib.nl/taverne-license

Take down policy

If you believe that this document breaches copyright please contact us at:

repository@maastrichtuniversity.nl

providing details and we will investigate your claim.
}

Copyright and moral rights for the publications made accessible in the public portal are retained by the authors and/or other copyright owners and it is a condition of accessing publications that users recognise and abide by the legal requirements associated with these

- Users may download and print one copy of any publication from the public portal for the purpose of private study or research.

- You may not further distribute the material or use it for any profit-making activity or commercial gain

If the publication is distributed under the terms of Article $25 \mathrm{fa}$ of the Dutch Copyright Act, indicated by the "Taverne" license above, 


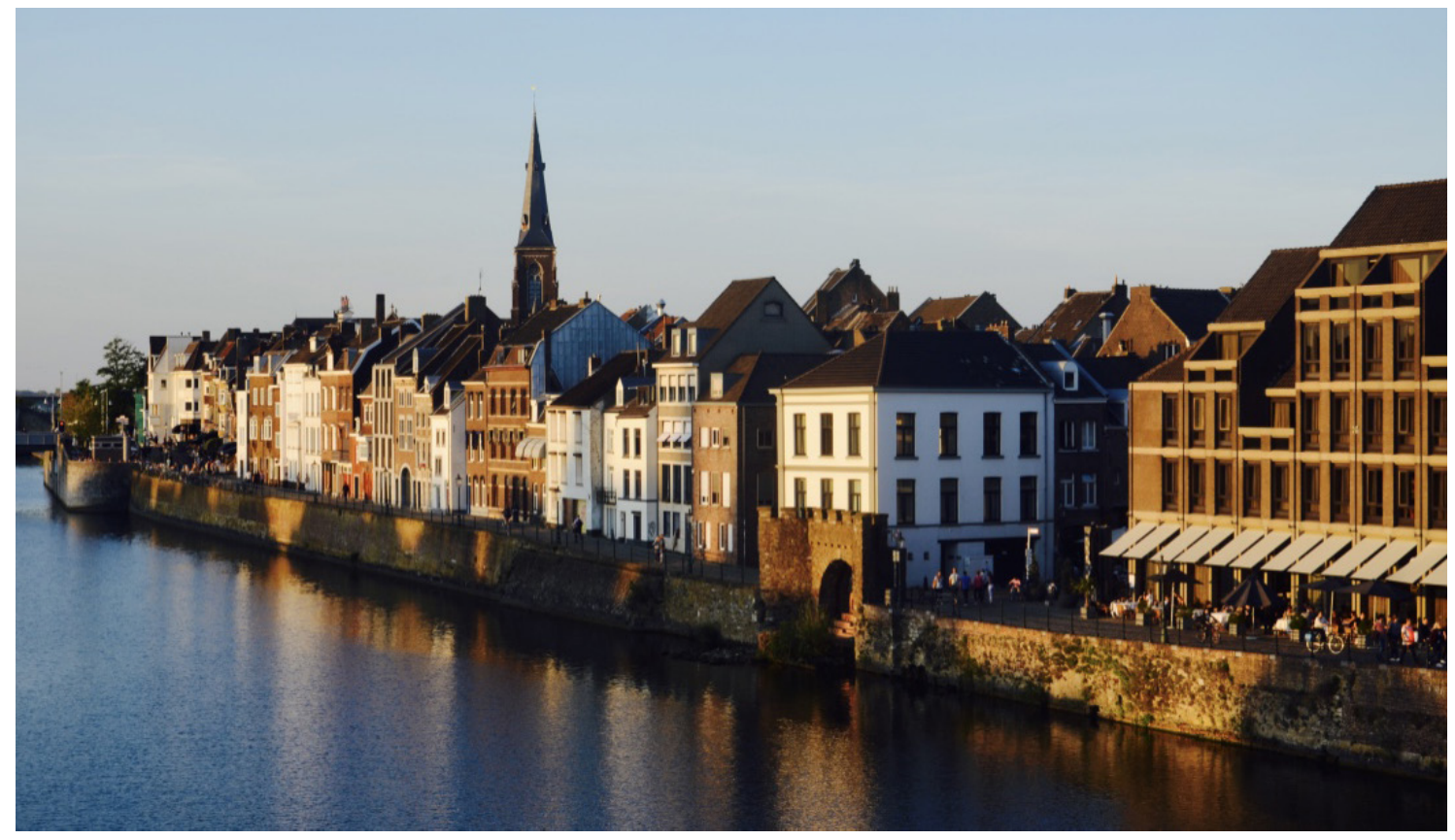

\section{THREE ESSAYS ON DEBT PRICING Mimiroglu}





\title{
THREE ESSAYS ON DEBT PRICING
}

\author{
Nagihan Mimiroglu
}

A thesis submitted in fulfillment of the requirements

for the degree of Doctor of Philosophy

at Maastricht University 
(C) 2020 Nagihan Mimiroglu

All rights reserved. No part of this publication may be reproduced, stored in a retrieval system, or transmitted in any form without the prior permission from the author in writing.

Cover by Nagihan Mimiroglu.

ISBN 978-94-6380-864-4

This book was typest using [ATEX. 


\section{THReE EsSAYS ON DEBT PRICING}

\section{DISSERTATION}

to obtain the degree of Doctor at Maastricht University, on the authority of Rector Magnificus Prof. Dr. Rianne M. Letschert, in accordance with the decision of the Board of the Deans, to be defended in public on Tuesday, 1 September 2020, at $10.00 \mathrm{am}$.

by

Nagihan Mimiroglu 
Supervisor:

Prof. Dr. J.W.B. Bos

Assessment Committee:

Prof. Dr. Dirk Broeders (Chair)

Prof. Dr. Hans Degryse (KU Leuven)

Dr. Ralph De Haas (EBRD and Tilburg University)

Dr. A.H.K. Renders 
Annem'e ve babam'a. 



\section{Acknowledgements}

First, I would like to express my gratitude to my supervisor Jaap Bos for his guidance. Jaap, I doubt if I could still finish this dissertation without your support. I thank you for your support and trust in me.

Second, I would like to thank the members of my assessment committee: Prof. Dr. Dirk Broeders, Prof. Dr. Hans Degryse, Dr. Ralph de Haas and Dr. Annelies Renders. Thank you for taking the time to evaluate my dissertation. I am honored to have you in my committee and grateful for your invaluable comments.

Special intellectual indebtedness goes to Pablo Ruiz-Verdú from whom I have learned a lot how to conduct research. I feel extremely fortunate to have the opportunity to learn from you. I am also indebted to Steven Ongena for giving me the opportunity to collaborate with him and being a great mentor to me. Steven, I also admire your commitment to our joint work despite your busyness. Furthermore, thank you for making possible my research visit in New York City. I would like to thank Iftekhar Hasan for hosting me at Fordham University and for feedback on my research projects. Likewise, I am also very grateful to Daniel Streitz - thank you again for the warm welcome in Copenhagen and valuable feedback on my work.

Further, I would like to thank all the faculty members at the Department of Finance of Maastricht University. Thank you for sharing your wisdom with me. I am also grateful to my fellow PhD students for many insightful discussions on research and the fun we had at various activities. A special thank you goes out to Matteo Bonetti - thank you for the co-working times at the weekends. Lidwien Sol and Mike Langen, it was so much fun to be officemate with you. I also would like to thank Irene Andersen, Inka Eberhardt, Marina Gertsberg, Matthijs Korevaar, Michael Kurz, Marten Laudi, Ming Li, Joyce Mertens, Nora Pankratz, Martijn Stroom, Adarajew Tamirat, Pomme Theunissen and Colin Tissen. Moreover, I also appreciated the support from Els van Aernsbergen, Cecile Luijten, Francieen Schijlen and Carina Wijnands.

Most importantly, I am grateful to my parents for their invaluable support. I also would like to thank Neslihan Chasse and Thierry Chasse, and Ebru Pottuijt and Paul Pottuijt for making my time in the Netherlands so much memorable. Markus, I am blessed to have you in my life. Thank you very much for your encouragement and unconditional support, and for our endless discussions. 



\section{Contents}

1 Introduction 1

2 Distance Effects in CMBS Loan Pricing: Banks versus Non-Banks 5

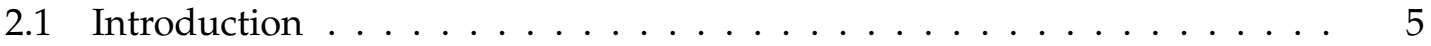

2.2 Theoretical Framework and Hypotheses . . . . . . . . . . . . . . . . . 9

2.2.1 Motivation . . . . . . . . . . . . . . . . 9

2.2.2 Hypotheses Development . . . . . . . . . . . . . . . . . . 10

2.3 Data and Variables . . . . . . . . . . . . . . . . . . . . . . . . . . . 13

2.3.1 Sample Construction . . . . . . . . . . . . . . . . . 13

2.3.2 Variables . . . . . . . . . . . . . . . . . . . . . 14

Measurement of Distance . . . . . . . . . . . . . . . . . 14

Mortgage Loan Characteristics . . . . . . . . . . . . . . . . . . . 15

Property Characteristics . . . . . . . . . . . . . . . . . 16

Other Control Variables . . . . . . . . . . . . . . . . . . 17

2.3 .3 Summary Statistics . . . . . . . . . . . . . . . . . . . . . 18

2.4 Results . . . . . . . . . . . . . . . . . . . . . . 18

2.4.1 Baseline Results . . . . . . . . . . . . . . . . . . . . 18

2.4.2 The Effect of Property Type . . . . . . . . . . . . . . . . . . . . 19

2.4 .3 Borrower-Property Distance and Spread . . . . . . . . . . . . . 20

2.4 .4 The Effect of Loan Size . . . . . . . . . . . . . . . . . . . . . . . 21

2.4 .5 The Effect of the 2008 Financial Crisis . . . . . . . . . . . . 22

2.4 .6 Default Analysis . . . . . . . . . . . . . . . . . 22

2.5 Robustness Tests . . . . . . . . . . . . . . . . . . . 23

2.5.1 Bank Branch-Borrower Distance . . . . . . . . . . . . . . . 23

2.5.2 Do Out-of-State Borrowers Pay More? . . . . . . . . . . . . . . . 24

2.6 Conclusion . . . . . . . . . . . . . . . . . . . 24

A Sample and Variables $\quad 41$

3 The American Inventors Protection Act: A Natural Experiment on Innovation Disclosure and the Cost of Debt 45

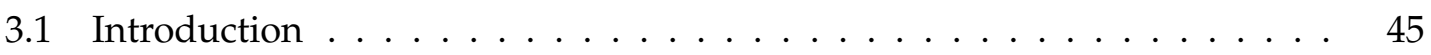

3.2 Data and Methodology . . . . . . . . . . . . . . . . . . 46

3.3 Results . . . . . . . . . . . . . . . . . . . 48

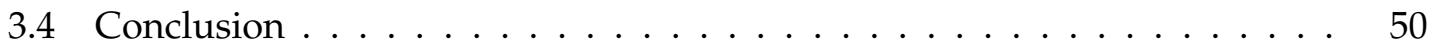

$\begin{array}{ll}\text { B Variables } & 57\end{array}$

4 The Effect of Voluntary Non-Financial Disclosure on Green Bond Pricing 59

4.1 Introduction . . . . . . . . . . . . . . . . . . . . 59

4.2 Literature Review . . . . . . . . . . . . . . . . . . . . . . . 62

4.3 Background and Hypotheses Development . . . . . . . . . . . . . . . 64 
4.3.1 The Development of the Green Bond Market . . . . . . . . . . . . . . . 64

4.3.2 Reporting and Disclosure . . . . . . . . . . . . . . . 65

4.3.3 Theoretical Motivation and Hypotheses Development . . . . . . 66

4.4 Data and Matching Method . . . . . . . . . . . . . . . . 68

4.5 Results . . . . . . . . . . . . . . . . . . . 70

4.5.1 Is There a Green Bond Premium? . . . . . . . . . . . . . . . 70

4.5.2 The Effect of Voluntary Disclosure . . . . . . . . . . . . . 71

The Disclosure Score . . . . . . . . . . . . . . . . . . . . . . 73

4.5.3 Experienced Issuers . . . . . . . . . . . . . . . . . . . . 74

4.5.4 Additional Tests . . . . . . . . . . . . . . . . . . 75

4.6 Conclusion . . . . . . . . . . . . . . . . . . . . . . . . 75

C Variables and Credit Ratings $\quad 85$

$\begin{array}{llr}5 & \text { Conclusion } & 87\end{array}$

$6 \quad$ Research Impact $\quad 89$

$\begin{array}{ll}\text { References } & 91\end{array}$ 


\section{List of Figures}

2.1 Distribution of Loan Volumes Originated by Years . . . . . . . . . . . . . 26

2.2 Distribution of Lender Headquarters . . . . . . . . . . . . . . . . . . 27

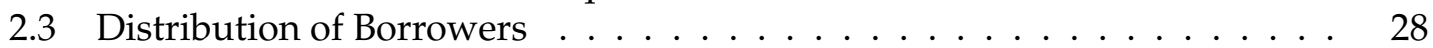

2.4 Distribution of Properties . . . . . . . . . . . . . . . . . . . . . . . . . . . . . . . . . . . . .

2.5 Spread by Years . . . . . . . . . . . . . . . . . . 30

4.1 Green Bonds by Country . . . . . . . . . . . . . . . . . . . . . . . 77

4.2 Green Bonds by Currency . . . . . . . . . . . . . . . . . . . 77 



\section{List of Tables}

2.1 Summary Statistics . . . . . . . . . . . . . . . . . . . . . . 31

2.2 Originator-Borrower Distance and Spread . . . . . . . . . . . . . . . . . . . . 32

2.3 The Effect of Property Type . . . . . . . . . . . . . . . . . . . . 33

2.4 Borrower-Property Distance and Spread . . . . . . . . . . . . . . . . . 34

2.5 The Effect of Loan Size . . . . . . . . . . . . . . . . . . . . . . . . . 35

2.6 The Effect of the 2008 Financial Crisis $\ldots \ldots \ldots \ldots$

2.7 Default Analysis . . . . . . . . . . . . . . . . . . . . . . 37

2.8 Bank Branch-Borrower Distance and Spread . . . . . . . . . . . . . . . 38

2.9 Out-of-State Borrowers . . . . . . . . . . . . . . . . . . . . . 39

A1 Distributions of Property Types . . . . . . . . . . . . . . . . . . . . . 41

A2 Variable Definitions . . . . . . . . . . . . . . . . 42

3.1 Summary Statistics . . . . . . . . . . . . . . . . . . . . 52

3.2 AIPA and The Cost of Debt for Innovative Firms . . . . . . . . . . . . . 53

3.3 Testing for Differences in Coefficients between Pre- and Post-AIPA Periods 55

B1 Variable Definitions and Sources . . . . . . . . . . . . . . . . 57

4.1 Summary Statistics . . . . . . . . . . . . . . . . . . 78

4.2 Green Bonds versus Conventional Bonds . . . . . . . . . . . . . . . 79

4.3 Fixed-Effects Model . . . . . . . . . . . . . . . . . . . . . . . . . . 80

4.4 Distribution of the Estimated Green Bond Premium . . . . . . . . . . . . 81

4.5 The Effect of Disclosure . . . . . . . . . . . . . . . . . . . . . . . 82

4.6 Experienced Issuers . . . . . . . . . . . . . . . . . . . . . . . . . 83

4.7 Robustness Test . . . . . . . . . . . . . . . . . . . . . . 84

C1 Variable Definitions . . . . . . . . . . . . . . . . . 85

C2 Credit Ratings . . . . . . . . . . . . . . . . . . . . . . . 86 



\section{Chapter 1}

\section{Introduction}

Asymmetric information is a fundamental concept for understanding debt financing. The lack of information occurs when lenders do not have information about the borrowers' creditworthiness (e.g., informationally opaque borrowers). Therefore, lenders may charge higher interest rates to compensate for the increasing risk. In some cases, beyond a lack of information, there is a lack of credibility of information. For example, if the information is not publicly available, firms try to sell information directly to lenders while issuing debt. However, it may be difficult for lenders to distinguish good information from bad one. In the context of debt financing, the theory of information asymmetry suggests that an imbalance of information between "informed" firms and "uninformed" lenders can lead to inefficient outcomes or even market failure as firms offering poor quality information can access the market (Leland and Pyle, 1977). One solution to overcome this information asymmetry problem is signaling.

A firm can choose between private debt (e.g., bank loans) and public debt (e.g., corporate bonds). This choice mainly depends on the degree of information asymmetry between firms and lenders. Some firms may desire confidentiality because of their product market, hence prefer private lenders to public lenders. For instance, R\&D-intense firms, that want to keep secrecy on their strategic information such as R\&D activities, may choose private over public debt in order to conceal private information (Kale and Meneghetti, 2011). Even tough these firms are typically regarded as equity-dependent firms, there is also growing literature on innovation and debt finance (e.g., Kerr and Nanda, 2015). In the context of bank financing, the uncertainty of R\&D investment payoffs is a potential source of asymmetric information and it is difficult for firms to signal their creditworthiness. The "informed" firm therefore faces a trade-off between disclosing strategic information and keeping it as confidential (Kale and Meneghetti, 2011). In order to obtain financing for its R\&D activities at a lower cost, the firm may disclose part of its technological information as a signal. If a firm reveals its strategic information to the marketplace, it may face the risk of losing its competitive advantage as it is likely that this proprietary information is valuable for the firm's rivals (Bhattacharya and Ritter, 1983). Therefore, private debt financing is of value to the firm's owners because it allows the confidentiality of information (Campbell, 1979). 
Further, within the set of sources for private debt, a firm can choose to borrow from a bank or a non-bank financial intermediary. Banks are "information producers" and have a comparative advantage in pricing the securities of firms that are difficult to value (Leland and Pyle, 1977; Campbell and Kracaw, 1980). Producing information is costly; however, banks may obtain cost advantages in information production through repeated interactions and intermediary services with their customers. This private information enables banks to be efficient lenders (Lewis, 1992). Moreover, regulations and capital requirements limit banks' risk taking ability. Thus, non-bank lenders penetrated the market and found success over the past decades. Evidence suggests that non-bank lenders serve riskier borrowers (Johnson, 1997; Carey, Post, and Sharpe, 1998; Denis and Mihov, 2003). This poses a major threat to financial stability as risk is shifted from banks to non-bank lenders if the non-banks are operating in the regulatory shadow. However, the question regarding the distinctive roles of different types of private lenders remains mostly unexplored.

Asymmetric information affects not only firm's choice of financing sources possibly also the cost of financing. Information asymmetry can raise the cost of capital for firms. When the information asymmetry is more severe, "uninformed" lenders require a risk premium to compensate the risk or credit rationing occurs as a consequence of the adverse selection problem. Disclosing certain information to lenders helps firms to signal their quality, hence can reduce their financing cost.

The following three projects in this dissertation are connected through their objective to advance our knowledge on the effects of asymmetric information in debt markets. Even though the projects focus on different debt markets, namely the CMBS market, the syndicated loan market and the green bond market, the dissertation contributes to the information aymmetry literature as a whole. Specifically, I address three different aspects of information asymmetry in loan and bond markets: In Chapter 2, I investigate whether geographical distance -as a proxy for absence of private information-is priced in the commercial mortgage-backed securities (CMBS) market by banks and non-bank lenders. In Chapter 3, I study the syndicated loan market, and examine the effect of patenting activity as a signaling tool for reducing innovative firms' cost of debt. In Chapter 4, I test the effect of third-party verification on the pricing of green bonds. In the remainder of this chapter, I provide a brief motivation and the main findings of each project.

CHAPTER 2 relates to banks versus non-bank lending. In this capter, I examine the relationship between loan spread and geographical distance in the commercial mortgagebacked securities (CMBS) market. By employing a proprietary data set of CMBS loan transactions, I investigate whether the geographical distance between lenders, borrowers and their properties is reflected in the pricing of US mortgages that were included in US CMBS pools. Through the use of securitization, banks continue to play a dominate 
role in commercial real estate lending (Kronovet, 1997). However, the composition of lenders has changed dramatically since the 2008 financial crisis, and non-bank lenders have become important players in the CMBS market. The role of geographical distance in loan transactions has been investigated in different market settings. Less well understood, however, is how different types of intermediaries set the price. I show that the loan spread increases with bank-borrower distance in the CMBS market. On the other hand, I do not find any effect of geographical distance for non-bank lenders.

In CHAPTER 3, I empirically test the propriety models considerations of information asymmetry. In particular, I study the pricing of loans granted to innovative firms in the syndicated loan market. I use Loan Pricing Corporation's Dealscan database for obtaining data on loans, and combine it with data from Compustat and PATSTAT. Specifically, I examine the impact of innovation disclosure through patenting on firms' cost of debt, focusing on the American Inventors Protection Act (AIPA). AIPA requires patent applications becoming public 18 months after filing whereas previously, patents applications were disclosed only after being granted. I find that pre-AIPA patents reduce the cost of debt only for the most innovative firms, while post-AIPA, this effect holds for all firms. I suggest signaling innovation quality via patents as the underlying mechanism that explains the negative relationship between patenting activity and the cost of debt.

CHAPTER 4, together with Chapter 3, contributes to the information signaling literature. In this chapter, I study the signaling to overcome the information asymmetry problems in the green bond market. In particular, I investigate the effect of third-party verification on the pricing of green bonds. As climate change is one of the greatest challenges of our time, new financing instruments, such as green bonds, have emerged. While the green bond market has been expanding rapidly in recent years, there is no international standard to ensure "greenness." Having no standards in the green bond market makes self labeling a concern for investors. Thus, a whole range of verification services has emerged to inform investors. But the question remains whether verification matters in terms of bond pricing. If third-party verification provides transparency to investors whether the bond actually have climate-related benefits, it reduces information asymmetry, which may in turn lower the issuer's cost of financing. In this chapter, by using data from Bloomberg, I compare green bonds and conventional bonds that are similar with respect to several relevant characteristics, except for the green label. I find that, on average, there is no significant premium for green bonds relative to conventional bonds. I then investigate how the voluntary disclosures of third-party verification relate to green bond pricing. The results of this project show that the yield differential between a green bond and a paired conventional bond can be significantly reduced if a green bond has a third-party verification. One possible explanation is that the third-party verification can boost investor confidence and protects against greenwashing by reducing information asymmetries between issuers and investors. 
In Chapter 5, I summarize the empirical findings of each of the three projects. Finally, in Chapter 6, I evaluate the research impact of this dissertation. 


\section{Chapter 2}

\section{Distance Effects in CMBS Loan Pricing: Banks versus Non-Banks}

\subsection{Introduction}

Banks have long been the main lenders in the commercial mortgage market. But that has been changing since the Great Recession. Non-bank lenders such as finance companies, pension funds, and insurance companies have become major players in the origination of commercial mortgage loans. For example, banks like Bank of America, Citigroup, JP Morgan, Morgan Stanley and Goldman Sachs collectively represented more than 90 percent of the CMBS loan origination business in 2012, but their share dropped to roughly 65 percent by the end of $2015 .^{2}$

In this paper, we evaluate the loan pricing and performance of non-bank lenders as opposed to banks, and we focus on the CMBS market. This market has some key advantages to study this problem. It involves a rather homogeneous product: loans without covenants, collateralized by rent-generating real estate assets. We can observe and control for the characteristics of these assets, which allows for a much cleaner comparison than would be possible for other types of commercial loans, which differ more strongly in loan covenants and collateral assets. Additionally, borrowers in the CMBS markets are from one unique industry, again making them more comparable than, for instance, syndicated loans, where borrowers are from industries that range widely. This offers an ideal setting to study the effects of heterogeneity in loan underwriters, comprising banks, as well as non-bank lenders such as finance companies, pension funds, and insurance companies.

Given banks' traditionally dominant role in wholesale lending, it is perhaps not very surprising that the finance literature mainly deals with bank lending, mostly ignoring

\footnotetext{
${ }^{1}$ This chapter is based on a working paper co-authored with Piet Eichholtz (Maastricht University), Steven Ongena (University of Zurich) and Erkan Yonder (Concordia University).

${ }^{2}$ New CMBS risk rules threaten smaller lenders' access, 2016.
} 
the non-bank lenders. Banks are considered to be skillful at monitoring borrowers, as they have access to private information through their relationships with these borrowers (Fama, 1985; James, 1987; Lummer and McConnell, 1989). Recently, Chernenko, Erel, and Prilmeier (2019), studying loans to borrowers from different industries, confirmed that banks have better access to safer borrowers than their non-bank competitors. Overall, researchers find that non-bank lenders are less likely to lend to more profitable borrowers, monitor their borrowers less, and put less covenants in their loan contracts than banks do. These studies raise an important question regarding the way non-bank lenders price their access to soft information, and whether that information is salient for subsequent loan performance. Answering these two questions is the main contribution of this paper. To the best of our knowledge, our paper is the first to investigate the differences in the impact of access to soft information on loan pricing and performance by comparing banks to non-bank lenders in a single setting, the CMBS market.

Geographic distance has been considered as a proxy for access to soft information, as we do in this paper. Specifically, we study the impact of geographic distance on loan pricing and performance, comparing banks and non-bank lenders. We focus on two dimensions of distance: the distance between originator and borrower, and the distance between borrower and real estate collateral.

Distance has mainly been employed as a proxy for access to soft information in studies of small business lending. Most of these studies find a negative distance-spread relation, which is attributed to spatial price discrimination (see, e.g. Petersen and Rajan, 2002; Degryse and Ongena, 2005; Agarwal and Hauswald, 2010): local lenders exploit their monopoly power and charge borrowers higher interest rates. There are also a few studies documenting a positive relationship for small business lending (Bellucci, Borisov, and Zazzaro, 2013) and for syndicated loans (Knyazeva and Knyazeva, 2012). The latter paper also demonstrates that banks are more likely to require covenants or collateral assets for distant borrowers. Overall, the literature has mixed findings on the impact of distance in debt markets, since pricing effects seem to be the result of two opposing forces: local monopoly power and access to soft information.

This points to an additional advantage of studying CMBS loans to answer questions about different lending practices of banks and non-banks. Borrowers in the CMBS markets are less subject to spatial price discrimination and rent extraction by lenders due to the supra-regional nature of this market and the degree of competition between lenders, most of whom are headquartered in the coastal regions of the US, and located faraway from inland real estate borrowers. So loan spreads are likely to be the result of access to soft information rather than local monopoly power. Indeed, Titman and Tsyplakov (2010) show that soft information is critical for the performance of commercial mortgage and CMBS originators. 
Besides being an ideal setting to study the main research question of this paper, the CMBS market is interesting in and of itself. This market played a key role in the financial crisis that led to the Great Recession, and it has received a lot of attention by government regulators since then. Loan pricing was and is a key concern, with the conventional wisdom being that risky assets got too much credit too cheaply. Furthermore, the CMBS market is a major source of funding for commercial real estate loans in the US, with an outstanding balance that peaked at USD 871 billion in 2007 and was around USD 495 billion in 2017, according to NAREIT. ${ }^{3}$ And finally, the coronavirus may lead to pressures in the CMBS market in terms of default (of hotels, retail, student-housing, and single tenant properties with non-credit worthy tenant) and lack of new issuances putting the focus once more on the importance of the prior collection of soft information. ${ }^{4}$

Geographical distance is likely to be salient and positively associated with the spread on loans securitized in the CMBS market for two main reasons: transportation costs and information costs. First, banks may face with transportation costs when screening borrowers. By screening, banks collect soft information on the borrower and collateral asset (Gehrig, 1998) and evaluate the performance of the borrower. If the borrower is distanced, transportation costs increase by travel costs and the lender could charge a higher spread to cover the costs following a simple rule of mark-up over marginal cost (Bellucci, Borisov, and Zazzaro, 2013). Knyazeva and Knyazeva (2012) document a positive relation between distance and the loan spread for large borrowers in the syndicated loan market, which they explain by the costly screening process for lenders.

Second, there could be information costs potentially increasing by geographical distance. The quality of the signals about the the borrower decreases by distance. As a result, uninformed lenders may charge higher spreads due to higher risk premia to an adversely selected pool of applicants rejected by potentially better informed lenders because of the "winner's curse" threat (Alessandrini, Fratianni, and Zazzaro, 2009).

Benefiting from observing collateral asset characteristics, we also hypothesize that the effect of originator-borrower distance on the spread should be more pronounced for riskier collateral assets. If information asymmetry is increasing in originator-borrower distance, this should matter most when the loan is collateralized by a risky property type, because it will be repaid from the cash flows generated by those properties. Hotel, industrial and retail property types have the most volatile cash flows, while rental apartments' cash flows are less risky (Titman, Tompaidis, and Tsyplakov, 2005).

Alternatively, we also evaluate the impact of distance between the borrower and the

\footnotetext{
${ }^{3}$ On the Other Side of the CMBS "Wall of Maturities," 2018.

${ }^{4}$ Coronavirus Will Lead to New High for U.S. CMBS Loan Defaults, 2020.
} 
property. For borrowers located farther away from their properties, asymmetric information about local market conditions should be more marked. For example, it might be difficult for those borrowers to distinguish between immediate income and future value of the cash flows generated by the property. To fully assess the quality of a building or its location, one needs to visit it, talk to tenants, and stroll around the area. Since lenders know this, we hypothesize that the loan spread increases with distance between borrower and property.

We use a data set of loans issued in the US over the period 2000-2017 that are subsequently securitized. The data set covers 26,303 conduit loans originated by US banks, bank holding companies and non-bank lenders exclusively for direct sale into the secondary market. The data set includes rich information on the loans and the properties, as well as information about the borrowers and the lenders.

Our results show that a greater lender-borrower distance is associated with higher loan spreads for banks but not for non-bank lenders. We find that the spread difference between a typical loan extended by a lender located in the direct vicinity of the borrower and a loan extended by a lender 893 miles away -the median distance in our sample for banks- is 17 basis points. To put this in perspective, the median loan size in the sample is USD 6 million, so this additional spread implies approximately USD 10,000 in additional annual interest costs. We also find that this effect is more pronounced for riskier collateral assets, such as industrial, retail, and office properties. For example, the additional annual interest cost to finance industrial properties is on average USD 22,000 higher than for apartments. Similarly, we analyze and show that the distance effect is less pronounced for large-sized loans, as they are more likely to be transparent. Overall, we find that banks price distance effects, and even more so when financing smaller and riskier assets. But while non-bank lenders aggressively expand their market share in the CMBS markets, they seem to ignore their potentially limited access to soft information in their loan pricing.

Besides loan pricing at origination, we also perform default analyses. We find a positive correlation between the originator-borrower distance and default probability for loans originated by banks and non-bank lenders. This indicates that access to soft information is a predictor of loan performance.

Taking our results in combination, it seems that commercial mortgage lenders would do well to consider distance in their loan pricing, as a proxy for soft information about borrowers and their collateral assets. The fact that non-banks seem to ignore it suggests that they engage in risky lending practices. 
The rest of the chapter is organized as follows. Section 2.2 presents the theoretical motivation for our empirical analysis. Section 2.3 describes the data and the measurement of the variables. Section 2.4 presents our empirical results, and Section 2.5 gives the results of additional robustness tests. Section 2.6 concludes.

\subsection{Theoretical Framework and Hypotheses}

\subsubsection{Motivation}

Theories of financial intermediation suggest that lenders must be given appropriate incentives for screening and monitoring (Hölmstrom and Tirole, 1997). In the "originate-tohold" model, this incentive is provided by the performance of the illiquid loans on their balance sheets (Diamond and Rajan, 2001; Keys et al., 2010). However, in the "originateto-distribute" model, lenders intend to offload credit risk after issuing loans (Purnanandam, 2011). Due to the lack of their own "skin in the game" as a result of securitization, the lenders' incentive to collect private information on loan quality is weakened, possibly to such an extent that the effects of moral hazard and adverse selection become apparent in subsequent loan performance (An, Deng, and Gabriel, 2009; An, Deng, and Gabriel, 2011; Black et al., 2012; Rajan, Seru, and Vig, 2015). In fact, this "lack of doing one's homework" due to securitization was exactly what many commentators and policy makers pointed to when seeking to explain the origins of the great financial crisis of $2008 .^{5}$

However, the securitization process of mortgage loans is a repeated game, in which a lender repeatedly originates loans that are then sold to CMBS purchasers (Rajan, Seru, and Vig, 2015). Due to this repeated nature of securitization, lenders have an incentive to build and maintain a good reputation for originating high-quality loans. The originator knows that issuing low-quality loans with a higher likelihood of poor performance will hurt his reputation and may lead to a loss of future economic rents. For example, if defaults are too high in a given year, CMBS purchasers can punish a lender by not buying his loans in the future (Titman and Tsyplakov, 2010; Rajan, Seru, and Vig, 2015). Thus, the need to build and preserve a good reputation could provide lenders with a non-contractual incentive to collect and screen soft information, and to use it in their loan acceptance and pricing.

Existing research has provided mixed evidence regarding securitization and the incentives for financial intermediaries to appropriately screen and monitor borrowers. Keys et al. (2010) investigate whether the securitization process reduces the incentives of financial intermediaries for careful screening of subprime mortgage loans in the US, and find evidence that it does. Conversely, by investigating both securitized and unsecuritized loans in the Italian prime mortgage market, Albertazzi et al. (2015) find that for given

\footnotetext{
${ }^{5}$ See, e.g., Luis A. Aguilar, "Speech by SEC Commissioner: Realigning Incentives in the Securitization Market," U.S. Securities and Exchange Commission, March 30, 2011.
} 
observable characteristics, securitized mortgages have a lower default probability than non-securitized mortgages. They show that the underlying mechanism is originator reputation; banks do seem to care about their reputation for not selling lemons.

However, these studies are limited to the residential mortgage market, with a focus on the subprime market, which is a very specific segment of the credit market. Much less is known about the CMBS market, which has very different characteristics to the market for residential mortgages. For example, unlike residential mortgage-backed security asset pools, which contain many residential mortgages, CMBS pools usually contain far fewer mortgages, due to the large size of commercial mortgages (Baghai and Becker, 2018). Therefore, CMBS have more concentrated real estate risk, and understanding the quality of each of the underlying loans and their real estate collateral becomes more important, especially since commercial property is much more heterogeneous than residential property. Moreover, CMBS loans have prepayment protection, making default risk more important.

Furthermore, for residential mortgages, loan originators tend to use standardized scoring systems that ignore soft information. However, soft information such as reliability of the owners and their tenants, the quality of a location, and possible alternative uses of property plays an important role for commercial mortgage origination (Titman and Tsyplakov, 2010). Since gathering soft information is likely to be costly, geographic distance becomes more important in the CMBS market.

Another important phenomenon in the CMBS market is the emerging trend in the composition of lender types. Using our sample, Figure 2.1 reflects the trend in the composition of commercial mortgage lending by banks and non-bank financial institutions. Before the crisis, banks dominated CMBS lending, but this reversed during the post-crisis period. Lending grew overall, but non-banks had a consistently higher market share in loan origination than banks. ${ }^{6}$ This development underscores the salience of our research questions as little is known about the lending behavior of these non-bank lenders. Their increase in market share can potentially indicate riskier lending behavior relative to banks, along with the likelihood of soft information being ignored.

\subsubsection{Hypotheses Development}

Economic theory suggests two causal factors in the role of geographical distance in loan transactions: transportation costs and information costs. First, borrowers and lenders may

\footnotetext{
${ }^{6} \mathrm{CMBS}$ issuance declined in 2016 due to many factors such as market uncertainty and implementation of new regulations. The Dodd-Frank Act requires issuers of all types of asset-backed securities to retain at least a 5 percent share of any security they issue, as determined by its fair value.The risk retention rule that is part of this act was implemented in December 24, 2016.
} 
incur transportation cost. If borrowers face higher transportation cost when visiting competing lenders, local lenders may engage in spatial price discrimination. Accordingly, local lenders accumulate market power and extract rents from nearby borrowers. Evidence of such spatial price discrimination is found in small business lending (Degryse and Ongena, 2005; Agarwal and Hauswald, 2010), which shows a negative relation between bank-borrower distance and interest rates. In the CMBS market, however, it is likely that borrowers are less subject to price discrimination by banks as they are not solely reliant on bank loans. Borrowers are able to raise financing from non-bank lenders, and banks do not know where their competitors are, given the wide geographic distribution of these lenders.

Banks may also incur transportation costs when screening borrowers. The screening process includes the evaluation of the financial performance of the borrower, and the effort by the bank management to obtain soft information on the borrower and the loan collateral (Gehrig, 1998). Any travel costs incurred by the bank make loan origination to distant borrowers costlier (Alessandrini, Fratianni, and Zazzaro, 2009). The cost a bank must incur to screen and monitor such a borrower is relative to the distance between the bank and the borrower (Sussman and Zeira, 1995; Almazan, 2002). Given that screening costs increase with bank-borrower distance, banks might incorporate this cost in loan terms by setting higher loan rates following a simple rule of mark-up over marginal cost (Bellucci, Borisov, and Zazzaro, 2013). In that case, the loan spread should be positively associated with bank-borrower distance. Indeed, Knyazeva and Knyazeva (2012) find a positive relation between distance and the loan spread for large borrowers in the syndicated loan market, which they attribute to the costly delegated monitoring process for lenders.

Second, geographical distance affects information costs incurred by both borrowers and lenders. Borrowers may incur search costs associated with information acquisition about loan products and conditions offered by alternative lenders (Alessandrini, Fratianni, and Zazzaro, 2009). Lenders may face information costs that vary with distance, as the quality of the signal that the lender receives decreases with the distance. In traditional lending (originate-to-hold), lenders are not willing to supply credit to distant borrowers who have been rejected by lenders with superior information, because of the "winner's curse" threat (Alessandrini, Fratianni, and Zazzaro, 2009). However, when uninformed lenders do provide loans to distant borrowers, they may charge higher risk premia due to the risk of granting loans to an adversely selected pool of applicants rejected by potentially better informed lenders.

It could be argued that if the borrowers or their real estate collateral are not nearby, 
lenders most likely rely on real estate agents' local market research to ameliorate information asymmetry problems. In that case, the spread might be lower given that the information asymmetry is thereby reduced. However, maintaining a relationship with real estate agents likely imposes a cost on the lenders (Alessandrini, Fratianni, and Zazzaro, 2009). Therefore, even if real estate agents are engaged in the loan underwriting process, the spread might still be higher due to the cost arising from distance.

One may wonder why originators are even willing to extend loans to faraway borrowers. This may have to do with the high competition in the CMBS market, driving conduit lenders to expand their radius. In this market, banks are competing with each other, but increasingly also with non-bank lenders operating in the regulatory shadows.

Given that the transportation and information cost effects on loan spreads point in the same direction, and that spatial price discrimination is less likely in the CMBS market, we expect that loan spread increases with distance between lender and borrower. We additionally expect this relationship to be more pronounced for banks compared to non-bank lenders.

Hypothesis 1: The loan spread increases with distance between lender and borrower.

Next, we consider how the loan spread varies with the property type. Commercial mortgage default varies systematically with property type (Vandell et al., 1993; Ciochetti et al., 2002; An, Deng, and Gabriel, 2011). Apartments are characterized by lower levels of uncertainty and less sensitivity to the business cycle than retail and office (An, Deng, and Gabriel, 2011), so multi-family loans are the least risky. If risk is increasing with originator-borrower distance, this should matter most when the loan is also collateralized by a risky property type, because the loans will be repaid from cash flows generated by those properties. Therefore, we argue that the effect of geographical distance on the loan spread should be more pronounced if loans are collateralized by a risky property type such as hotel or industrial property. We also expect that banks might pay more attention to the riskiness of the collateral asset compared to non-bank lenders.

Hypothesis 2: The increase in loan spread by the distance between lender and borrower is more pronounced for riskier property types.

Garmaise and Moskowitz (2004) argue that information considerations are important in real estate markets for two reasons. First, the real estate market is illiquid, so conveying information to market participants is a slow process. Second, real estate assets are idiosyncratic and difficult for non-locals to value. They employ the distance between borrower and property as an indirect proxy for asymmetric information. By testing the 
implications of the "no trade" theorem of Milgrom and Stokey (1982), they find that market participants resolve information asymmetries by purchasing nearby properties. For borrowers located closer to the properties, information about local market conditions is less asymmetric, so the lender receives a more precise signal about those borrowers' understanding of local market conditions. The distance between borrower and property is highly relevant in the CMBS market, since this market allows CMBS investors to invest easily in a variety of geographic locations for diversification reasons. Therefore, we expect that lenders predicate their loan pricing on borrowers' access to soft information regarding local market conditions, which would imply a positive relationship between loan spread and borrower-property distance. Similarly, we expect this relationship to be more prominent for banks compared to non-bank lenders.

Hypothesis 3: The loan spread increases with distance between borrower and property.

We now turn to our data set we use to test these hypotheses.

\subsection{Data and Variables}

\subsubsection{Sample Construction}

We use a data set of commercial mortgages provided by Real Capital Analytics Inc. (RCA), a leading data provider in commercial real estate. Our primary sample of CMBS conduit loans includes 55,892 commercial mortgages that were originated between January 2000 and August 2017. The loan originators in the larger data set are heterogeneous in terms of their financial activities. The categories include banks, corporate, developer/owner/operator, equity fund, finance, government, insurance, investment manager, pension fund, REIT, REOC, and religious institutions. The largest category in the data set is "Bank." We classify all other types of originators as "Non-bank."

We exclude syndicated loans and focus exclusively on sole-lender loans. Similarly, we exclude loans to multiple borrowers. Following the loan pricing literature, we drop the loans to Real Estate Investment Trusts and banks from the sample. Finally, we exclude non-US lenders as well as borrowers located outside the US. The final sample includes 26,303 loans for 24,885 unique real estate properties to 8,538 unique borrowers.

The market for commercial property conduit loans is quite concentrated. Wells Fargo, Citigroup, JP Morgan, Ladder Capital, Morgan Stanley, Berkadia, Bank of America and Goldman Sachs are among the top ten originators, and together comprise 46.9 percent of our sample. 
Table A1 shows the sample distribution by property type. The apartment is the most common type of collateral property. 36.27 percent of the collaterals for the loans originated by the banks are apartments, while 54.07 percent of the collaterals for non-bank loans are apartments. Overall, this implies that the non-bank lenders' collateral portfolio has lower levels of uncertainty and less sensitivity to the business cycle.

\subsubsection{Variables}

Our sample provides information on the loans, the collateralizing properties, the lenders and the borrowers. We will use this subsection to present and discuss all variables. We begin with the distance variable, which is our key explanatory variable. Table A2 provides information regarding the definition of all variables used in the study.

\section{Measurement of Distance}

We calculate distances using geographic coordinates. ${ }^{7}$ RCA data contains latitudes and longitudes for borrower, property and headquarter of the lender. CMBS loans are typically so large and complex in comparison to other mortgages that on the depositor side, Regulation AB II requires a certification by the chief executive officer (CEO) of the depositor stating that the securitization is structured to produce cash flows in amounts sufficient to service scheduled payments on the securities. ${ }^{8}$ Hence, the senior management team of a lender is likely to be involved in the loan approval decision, term setting and loan pricing. We therefore focus on the locations of lenders' headquarters. ${ }^{9}$ We do also consider the possibility of local branch involvement in the loan application process, and assess the effect of branch location, in the robustness section.

Because of the possible nonlinearity of the economic impact of distance, we employ a logarithmic transformation of distance. From an economic perspective, this transformation implies that the impact of a marginal increase of distance between 0 and 50 miles is not equal to an increase between 1000 and 1050 miles. Ln(1 + Distance Originator-Borrower $)$ is defined as the natural logarithm of one plus distance (in miles) between the originator headquarter and the borrower. Similarly, we define $\operatorname{Ln}(1+$ Distance Originator-Property $)$ and $\operatorname{Ln}\left(1+\right.$ Distance $\left._{\text {Borrower-Property }}\right)$.

Figure 2.2 shows a map of the US depicting the headquarter locations of the originators. New York accounts for twenty-five observations, including the headquarters of Citigroup, JP Morgan, Ladder Capital and Morgan Stanley which are among the top ten

\footnotetext{
${ }^{7}$ It is also possible to measure travel distance (see, e.g. Giroud, 2013), but we calculate the shortest distance.

${ }^{8}$ Asset-Backed Securities Disclosure and Registration

${ }^{9}$ Unlike in studies on small business lending, top management involvement in the lending decisions is also argued in the syndicated loan market (see, e.g. Knyazeva and Knyazeva, 2012; Hollander and Verriest, 2016).
} 
originators in our sample. Another relevant concentration is in California with twelve observations, including Wells Fargo. First National Bank Alaska is headquartered in Alaska, which is not shown on the map.

Figure 2.3 shows the distribution of the 8,510 borrowers of our sample across the US. Although we observe clusters of borrowers in the major urban areas in the West and the North East, we also have a sizeable number of borrower observations in other regions. Of all loans in the sample, 21.33 percent are to borrowers in California, mostly clustered in the major urban centers like the San Francisco Bay area and Los Angeles. New York and Florida are the other two states with major borrower clusters, with 11.21 percent and 5.57 percent of our sample located in these states, respectively.

Figure 2.4 shows the distribution of locations for the 24,812 properties in the sample. The map shows that the main US urban areas are all represented in the sample, with California, Texas and Florida the most important locations: 31.50 percent of the loans are collateralized by properties located in these states.

\section{Mortgage Loan Characteristics}

Our dependent variable Spread is mortgage spread. We define mortgage spread as the difference between the mortgage rate and the Treasury bond rate with the same maturity, at the mortgage origination date. We restrict our sample to fixed-rate mortgages. Figure 2.5 shows the average loan spread over time, plus and minus one standard deviation. For each year, the dot depicts the mean spread, and the bar shows the plus and minus one standard deviation range. The blue line shows the average spread, $225 \mathrm{bps}$, for the whole sample period. We see that there is a sharp increase in average spread during the 2008 financial crisis, and that the standard deviation of loan spreads is very large in 2009. Although spreads have come back down after the crisis, they are not as low as they were between 2003 and 2007, and seem to be hovering around their average level for the sample period.

Standard risk considerations of commercial loan underwriting involve the loan-tovalue ratio (LTV). The LTV ratio of a loan is measured as the loan amount divided by the appraised value of the real estate collateral. Previous studies find that LTV is correlated with loan performance (Archer et al., 2002; Ambrose and Sanders, 2003), and that LTV is an important predictor of default risk (An, Deng, and Gabriel, 2011). We therefore expect LTV to be positively related to mortgage spreads.

Along with LTV, the debt service coverage ratio (DSCR) is another important predictor of default risk. DSCR measures the ability of a commercial property to cover debt 
service payments from the rental revenue. After the 2008 financial crisis, financial institutions were heavily criticized for the relaxation of pre-crisis underwriting standards, for example by basing the DSCR on estimates of future rents, rather than on actual or historical rental income (Black et al., 2012). We anticipate that DSCR is negatively correlated with the spread.

We also control for observable loan characteristics such as loan size and loan maturity. We expect that loan size is negatively related to spread due to economies of scale in lending. That is, the costs of making loans to small borrowers tend to be relatively greater than the costs of making loans to large borrowers. We similarly control for loan maturity and expect that this negatively affects spreads on CMBS loans. Commercial mortgages with a longer maturity have a lower default risk than those with a shorter maturity (An, 2007).

\section{Property Characteristics}

Our data on the collateral properties is quite rich. We have six property types in the data set: rental apartment, hotel, industrial, office, retail and other. We construct six indicator variables for these property types and use "apartment" as the base case in the regressions. The most common property type is apartment, with 42.46 percent of the loans collateralized by apartment assets. Apartments are characterized by lower levels of uncertainty and less sensitivity to the business cycle than retail and office (An, Deng, and Gabriel, 2011), whereas properties with volatile and cyclical cash flows such as industrial and hotels are viewed as the riskiest forms of commercial property collateral. We therefore expect loans to finance apartments to have lower spreads, followed by office, retail and hotel with industrial property loans having the higher spreads.

Titman, Tompaidis, and Tsyplakov (2005) find that newer properties have lower spreads. This is likely because property age is a proxy for quality. Older properties are likely to be of lower quality, with a lower structure value relative to land value, increasing the moneyness of the redevelopment option, and therefore increasing the likelihood of redevelopment. This flexibility is likely to increase the spread (Titman, Tompaidis, and Tsyplakov, 2005). Moreover, the age of a property is also a proxy for the degree of information asymmetry (Garmaise and Moskowitz, 2004). Properties with longer cash flow histories provide investors with more information about the property and local market conditions. We have the age of the properties at the mortgage origination date. Since it is likely that the age of the property does not affect the spread linearly, we use indicator variables for different age categories: less than 10 years old, between 10 and 20, between 20 and 30, between 30 and 40, between 40 and 50 and more than 50 years old. This argument about higher spreads for mortgages on properties with more investment flexibility also applies to properties that can be renovated (Titman, Tompaidis, and Tsyplakov, 2005). We therefore include an indicator variable that equals one if the property 
has been renovated.

We also control for height of the properties. The number of stories can be associated with spread for a variety of reasons. First, properties with a large number of stories generate additional rental income. For example, in some cities such as New York City, where land costs are high and plot sizes are small, building height is more important for total rentable space than the horizontal area (Barr, 2010). Second, there may be economies of scale associated with lower transaction costs in making loans to larger properties (Titman, Tompaidis, and Tsyplakov, 2005). For 65 percent of our sample, the number of stories is equal to one. Therefore, we define an indicator variable, Number of Stories $>1$, for the properties which have more than one story.

Another important factor in real estate quality and risk is the location. Assets located in or near a city's central business district tend to have less vacancy risk in down markets. This implies that their rental cash flows are less dependent on the business cycle. We therefore define an indicator variable for whether the property is located in the central business district (CBD). We expect the spread to be lower for loans involving properties located in CBDs.

\section{Other Control Variables}

In addition to these mortgage and property-specific variables, we also include a set of other variables that are known to affect loan spreads. Specifically, we include yearquarter time fixed effects to control for interest rate conditions that vary from quarter to quarter. We also include indicator variables for stated loan purposes: property acquisition or refinance. Following the literature (Ciochetti et al., 2002; Ambrose and Sanders, 2003; Titman and Tsyplakov, 2010; An, Deng, and Gabriel, 2011), we also introduce fixed effects for the state where the property is located, as commercial mortgage default varies with geographic location. As a proxy for the level of competition in a state, we include the log of the Herfindahl-Hirschman Index (HHI) of originator concentration in the state in which the borrower is located. We construct the HHI based on the market share by loan amount of each originator in a given state and year. A higher HHI means that concentration is high, possibly reducing spreads.

Existing research, for example An, Deng, and Gabriel (2011), argues that investors pay a substantial premium for CMBS loans originated by lenders who have a strong reputation for strict underwriting in the commercial mortgage market. In order to take lender reputation into account, we include lender fixed effects in all models. 


\subsubsection{Summary Statistics}

Table 2.1 provides summary statistics of the key variables. The spread has a mean value of 224 basis points and a median value of 225 basis points. The spread on non-bank loans is on average significantly higher than the spread on bank loans.

Average originator-borrower distance is 1,131 miles, and lenders are located, on average, 1,083 miles away from the property collateral. The shortest distance is the one between borrower and property and it is, on average, 537 miles. The distance series are skewed; the median originator-borrower distance is 928 miles, the median originatorproperty distance is 926 miles, and the median borrower-property distance is 209 miles.

The average LTV is 65 percent, with apartments having the highest LTV ratios at an average of 67 percent, and hotels the lowest, at an average of 61 percent. This pattern supports the view that LTV ratios are endogenously chosen to allow for the riskiness of the property type (Titman, Tompaidis, and Tsyplakov, 2005). The average DSCR is 1.74. The average maturity for loans is 118 months. The average loan size is USD 11 million, with a median size of USD 6 million. The largest loan is for USD 1.035 billion, for an office building in Manhattan.

On average, 6 percent of the loans are collateralized by the properties located in a central business district (CBD), and 27 percent of the properties are renovated. The HHI equals 0.05 , on average.

\subsection{Results}

\subsubsection{Baseline Results}

We now turn to our estimation results. We first test whether distance between lenders and borrowers is priced after controlling for observable mortgage and property characteristics. Table 2.2 presents the OLS estimates of Equation (2.1) using mortgage origination by banks, non-banks and all types of lenders. $X_{i}$ represents a vector of control variables, such as loan purpose, MSA, state where the property is located, originator, borrower and year-quarter time fixed effects.

$$
\begin{aligned}
\text { Spread }= & \beta_{0}+\beta_{1} \operatorname{Ln}\left(1+\text { Distance }_{\text {Originator-Borrower }}\right)+\Sigma \alpha_{i} \text { Property Characteristics }+ \\
& \Sigma \gamma_{i} \text { Mortgage Characteristics }+X_{i}+\epsilon
\end{aligned}
$$

The results in Table 2.2 show that the coefficient on $\operatorname{Ln}\left(1+\right.$ Distance $\left._{\text {Originator-Borrower }}\right)$ is positive and statistically significant for the full sample. When we repeat our analysis for the subsample of banks, columns (3) and (4) show a positive and statistically significant coefficient on $\operatorname{Ln}(1+$ Distance Originator-Borrower $)$, suggesting that the spread increases with 
distance between bank and borrower. The estimates are also economically significant. Holding other variables constant, a 100 percent increase in distance is on average associated with a 2.5 basis points increase in spread (column (4)). Summary statistics in Table 2.1 show a median distance of 893 miles, so our model would predict a 17 basis points increase in spread. Thus, for a median loan (USD 6 million), the increase in total interest costs would be USD 10,000. In columns (5) and (6), we do not find any significant effect of geographic distance on loan pricing for the loans originated by non-bank lenders.

We find that bank-borrower distance is positively associated with the loan spread. These results are at odds with previous literature showing a negative relationship due to spatial price discrimination. Naturally, such price discrimination, and thus bank hold-up problem, is less likely in the CMBS market, as borrowers are able to raise financing from non-bank lenders. Instead, we attribute our results to marginal cost pricing or adverse selection.

Control variables enter with the expected signs. Consistent with the literature that has found lower default risk for commercial mortgages with longer maturities than those with shorter maturities, we find a negative relationship between loan maturity and spread. The spread is also significantly lower for larger loans. The coefficient on the loan to value ratio also has the expected positive sign, and when we replace the loan to value ratio with the debt service coverage ratio (columns (2), (4) and (6)), we find that the results are robust for including DSCR as a control variable. Unsurprisingly, the DSCR variable is statistically significant and negative, indicating that a higher DSCR reduces the spread. For banks and all types of lenders, the property type coefficients are in line with expectations in the sense that loans for the riskier property types have higher spreads, and that loans financing apartments, the omitted category in the regression, have the lowest spreads, also in line with their lower risk. For non-bank originators, only the categories hotel and other type are positively related to spread. Building height and a central business district (CBD) location do not seem to play a role in CMBS loan spreads.

\subsubsection{The Effect of Property Type}

Next, we employ property type interactions in a similar fashion to An, Deng, and Gabriel (2011). Mortgage loans collateralized by apartments are much more homogeneous, and therefore easier to judge, than hotel, retail, office and industrial loans, suggesting that the effect of distance should be stronger for the latter property types. To explore this hypothesis, we include interaction terms between main property types and $\operatorname{Ln}(1+$ Distance Originator-Borrower). In our estimation, the baseline is apartments (as in Titman, Tompaidis, and Tsyplakov (2005)). Table 2.3 presents the results. The estimated coefficients of the interaction terms are positive and statistically significant for industrial, office, and retail properties for banks, but not for non-banks. In particular, we find that the effect of originator-borrower distance on spread is more pronounced for mortgages collateralized 
with riskier property types, since the interaction terms are highest for industrial and hotel properties. This effect is also economically significant. For example, the additional interest cost for a median loan is USD 22,000 for industrial properties relative to apartments.

\subsubsection{Borrower-Property Distance and Spread}

We also consider the distance between borrower and property as an indirect measure of information asymmetry, and we also expect that increasing distance is associated with higher spreads here. Garmaise and Moskowitz (2004) argue that buyers located closer to a property likely have a better understanding of local market conditions and can more easily and cheaply evaluate the property. Ling, Naranjo, and Petrova (2018) show that distant buyers tend to overpay in the commercial property market. Eichholtz, Holtermans, and Yonder (2016) find that office properties owned by distant investors have lower occupancy. If originators are aware of this, they will prefer borrowers that are close to their assets, which may be reflected in loan pricing.

In order to differentiate borrower distance to the originator, we create an indicator variable, $D$, which is equal to one if $\operatorname{Ln}\left(1+\right.$ Distance $\left._{\text {Originator-Borrower }}\right)$ is smaller than $\operatorname{Ln}\left(1+\right.$ Distance $\left._{\text {Originator-Property }}\right)$. We also define Minimum $_{\text {Distance }}=\{\operatorname{Ln}(1+$ Distance Originator-Borrower $), \operatorname{Ln}\left(1+\right.$ Distance $\left.\left._{\text {Originator-Property }}\right)\right\}$.

$$
\begin{aligned}
\text { Spread }= & \beta_{0}+\beta_{1} \text { Minimum }_{\text {Distance }} \times D+\beta_{2} \operatorname{Ln}\left(1+\text { Distance }_{\text {Borrower-Property }}\right) \times D+ \\
& \Sigma \alpha_{i} \text { Property Characteristics }+\Sigma \gamma_{i} \text { Mortgage Characteristics }+X_{i}+\epsilon
\end{aligned}
$$

We report the results in Table 2.4. The coefficient on $\operatorname{Ln}(1+$ Distance Originator-Borrower $)$, when borrower is closer to originator relative to property, is positive and statistically significant at the $5 \%$ level for banks, but not for non-bank lenders. That is, spread increases with distance between originator and borrower. However, the economic effect is relatively small in comparison to our baseline results and is USD 5400 for a median loan.

In columns (3) and (4), we also find a weakly significant and positive effect for borrowerproperty distance if the property is located closer to the originator relative to the borrower $(D=0)$. Conversely, we find a significant and negative effect for borrower-property distance if the borrower is located closer to the originator relative to the property $(D=1)$.

One possible explanation for these contradictory results is that the borrower-property distance does not matter for our borrowers given their expertise and industry focus. Our findings are therefore more in line with Conklin, Diop, and Qiu (2018) who argue that information asymmetries are likely to be relatively small for REITs when investing at a 
distance, and contradict the informational argument in Garmaise and Moskowitz (2004).

One may be concerned that originator-borrower distance may not be exogenous due to the omitted variable problem. Borrower, bank, and year-quarter time fixed effects account for selection on time-invariant borrower and bank characteristics as well as aggregate time-variation, but the specification may still be subject to possible selection on basis of time-varying borrower characteristics that the econometrician cannot observe (Karolyi, 2018). That is, unobserved borrower quality may be correlated with originator-borrower distance (i.e., borrowers can strategically choice their lenders). Therefore, estimation of the impact of distance could be biased. Ideally we would overcome this problem with instrumental variable approach. However, if we instrument originator-borrower distance, we also need to instrument borrower-property distance. Unfortunately, it is not straightforward to find an instrument for borrower-property distance.

\subsubsection{The Effect of Loan Size}

Thus far, we find that loan spreads increase with originator-borrower distance. In this section, we analyze the impact of loan size on originator-borrower distance and loan pricing. Previous literature (e.g. Wittenberg-Moerman, 2008) argues that loan size is typically positively correlated with borrower size. The effect of distance might be more pronounced for small-sized loans because small borrowers are more subject to asymmetric information problems. In contrast, large borrowers are usually more transparent. Moreover, a larger loan could enjoy a lower spread due to economies of scale in underwriting. To investigate these predictions, we split our sample into three groups based on the loan size and create two indicator variables: (i) Small Loans, which takes a value of one for loans in the lower tercile, and zero otherwise, and (ii) Large Loans, which takes a value of one for loans in the top tercile, and zero otherwise.

Table 2.5 presents the results. As before, the coefficient on $\operatorname{Ln}(1+$ Distance Originator-Borrower) is positive and statistically significant for banks, but not for non-banks lenders, meaning that loan spread is increasing with bank-borrower distance. In all columns, in addition to the $\operatorname{Ln}\left(1+\right.$ Distance $\left._{\text {Originator-Borrower }}\right) \times$ Small Loans interaction we also include the interaction of $\operatorname{Ln}(1+$ Distance Originator-Borrower $) \times$ Large Loans. Thus, the coefficient on the interaction term should be interpreted as the marginal effect of loan size as compared with loans in the middle group.

In columns (3) and (4) of Table 2.5, the coefficient on $\operatorname{Ln}\left(1+\right.$ Distance $\left._{\text {Originator-Borrower }}\right)$ $\times$ Small Loans is not significant, but the coefficient on $L n\left(1+\right.$ Distance $\left._{\text {Originator-Borrower }}\right)$ $\times$ Large Loans is negative and statistically significant at the $5 \%$ level. This suggests that the effect of bank-borrower distance on spread is less pronounced for larger loans relative to the middle group, and that this holds true for both lender groups. 


\subsubsection{The Effect of the 2008 Financial Crisis}

To rule out the possibility that our findings are mainly due to the 2008 financial crisis, we construct an indicator variable, Post-crisis, which is equal to one for the years after 2009, and interact it with $\operatorname{Ln}\left(1+\right.$ Distance $\left._{\text {Originator-Borrower }}\right)$. Specifically, we estimate the model in Equation (2.3):

$$
\begin{aligned}
\text { Spread }= & \beta_{0}+\beta_{1} \operatorname{Ln}\left(1+\text { Distance }_{\text {Originator-Borrower }}\right)+\beta_{2} \text { Post-crisis }+ \\
& \beta_{3} \operatorname{Ln}\left(1+\text { Distance }_{\text {Originator-Borrower }}\right) \times \text { Post-crisis }+ \\
& \Sigma \alpha_{i} \text { Property Characteristics }+\Sigma \gamma_{i} \text { Mortgage Characteristics }+X_{i}+\epsilon
\end{aligned}
$$

Table 2.6 presents the regression results. The estimate on Post-crisis is positive for both lender types, but only statistically significant for banks. This suggests that spreads have gotten higher since the 2008 financial crisis for bank originators, but that non-bank originators have adjusted their pricing behavior less than banks. The interaction term between Post-crisis and $\operatorname{Ln}\left(1+\right.$ Distance $\left._{\text {Originator-Borrower }}\right)$ is statistically insignificant across all the columns of Table 2.6.

\subsubsection{Default Analysis}

Our analysis consistently shows that loan spread increases with bank-borrower distance. A logical question is whether this effect is due to the information cost (adverse selection hypothesis) or transportation cost (screening hypothesis/marginal cost pricing). It is very difficult to make this distinction in the absence of a natural experiment, but we can use auxiliary data on loan performance based on the assumption that loan performance is positively correlated with borrower creditworthiness.

Unfortunately, we do not have data on mortgage histories up until their maturities in our data set. However, we have information about the status of a total of 1,097 mortgages that are defined as "resolved," "restructured/extension" and "troubled." We classify them all as defaulted mortgages. The 1,097 mortgages that we label as defaulted represent 4.1 percent of our total sample.

Because some loans in the sample had not reached maturity at the time of observation, we estimate the Cox proportional hazards $(\mathrm{CPH})$ model, to account for a possible right-censoring problem, which is a standard tool in the CMBS literature for default analysis. We test whether distant borrowers are more likely to default. If all the information associated with borrower risk is captured by hard information, we would not expect the coefficient of the distance variable to be significant.

Table 2.7 presents the result. The estimates are expressed in terms of hazard ratios. A hazard ratio of less than one indicates a decrease in the probability of default, whereas a 
hazard ratio greater than one indicates an increase in the probability of default. In column (2), we report the estimates for our bank sample, where we measure bank-borrower distance using lender headquarters. Hazard ratio is not statistically significant.

In column (3), we replace bank headquarter-borrower distance with bank branchborrower distance. The estimate for bank branch-borrower distance is greater than one and statistically significant at \%1 level, which suggests that greater bank branch-borrower distance predicts a greater probability of default. Controlling for spread, the estimate is statistically significant, which suggests that all the information relating to mortgage risk is not captured by hard information at the time of origination.

In column (4), we report the estimates for our non-bank sample. Greater distance predicts a greater probability of default. Overall, our findings indicate that distance between the originator and the borrower predicts default, and increases default probability for both banks and non-banks. However, our analysis in the previous sections shows that only banks incorporate distance into their loan pricing. This indicates that non-bank lenders conduct riskier lending in the CMBS markets.

\subsection{Robustness Tests}

In this section, we perform several robustness tests.

\subsubsection{Bank Branch-Borrower Distance}

Throughout our analysis, we focus on the locations of banks' headquarters. However, it is likely that local bank branches also engage in the administrative and screening process of the loan application. Therefore, in this section, we repeat our baseline regression with bank branch-borrower distance instead of distance relative to headquarters.

We obtain bank branch data from the SNL Financial LC. We discard observations if a branch was not open when the loan was issued, and subsequently calculate the borrower's distance to the nearest branch. The results are presented in Table 2.8. The coefficient remains positive and statistically significant at the $1 \%$ level for most specifications after controlling for observable property and mortgage characteristics. The magnitude of the coefficient on distance is comparable to that which we reported in columns (3) and (4) of Table 2.2, but is slightly smaller, which makes sense given the smaller average distance between borrowers and branches relative to headquarters. So, we can conclude that our key distance result is robust to this alternative specification of bank location. 


\subsubsection{Do Out-of-State Borrowers Pay More?}

Next, we investigate whether our results are robust to the inclusion of an additional measure of distance: distance in jurisdiction rather than in miles.

Existing studies show that out-of-state investors pay economically meaningful premiums relative to their in-state counterparts. This premium is found both for apartment complexes (Lambson, McQueen, and Slade, 2004), office buildings (Ling, Naranjo, and Petrova, 2018) and commercial real estate markets in general (Agarwal, Sing, and Wang, 2018). The likely reason is that local investors have informational advantages relative to their out-of-state counterparts. For local investors, it is easier and cheaper to obtain local soft information by inspecting buildings and locations, reading local newspapers, and interacting with residents and other building users. Thus, they have superior information relative to non-local investors (Agarwal, Sing, and Wang, 2018).

To test whether the previously found effect of distance on spread is due to the outof-state effect, we define an indicator variable: "Out-of-State Borrower" is equal to one if borrower and property are not located in the same state, and zero otherwise. Moreover, following Agarwal, Sing, and Wang (2018), we only include loan transactions in which the borrower appears for the first time in the host state. ${ }^{10}$ That is, if the borrower has more than one loan in a host state, we only include the first loan.

We present the estimated results in Table 2.9. In columns (1), (3) and (5), we run the regressions for "first-time borrowers," and find that controlling for the "out-of-state effect" does not meaningfully affect the coefficients on $\operatorname{Ln}(1+$ Distance Originator-Borrower $)$. In columns (2), (4) and (6), we run the regressions for the loans originated by all types of lenders, banks and non-banks, respectively, and find similar effects to before. Across all the columns of Table 2.9, "Out-of-State Borrower" remains insignificant.

\subsection{Conclusion}

Banks have traditionally been the dominant players in wholesale lending, and non-bank lenders have gained important market shares only recently. The literature reflects this: hitherto, non-bank lenders have been all but ignored. Benefiting from the major change in lender composition in the CMBS markets, we analyze how banks and non-bank lenders deal with soft information -as proxied by originator-borrower distance- in CMBS loan pricing.

We show that the loan spread increases with originator-borrower distance in the CMBS market only for banks. This effect is more pronounced for the riskier property

\footnotetext{
${ }^{10}$ Of course, we can only assess this as far as our data set goes, and it may be possible that a borrower has been active in a city without appearing in our data set. So this variable is estimated with some error.
} 
types and less pronounced for large-sized loans. On the other hand, we do not find any effect of geographical distance for non-bank lenders. The new market entrants do not seem to incorporate soft information in their initial loan pricing. This is important, since our loan default analysis shows that distance matters for loans originated by both banks and non-bank lenders. Loans made out to distant borrowers are more likely to get into trouble. To gain market share in the CMBS market, non-bank lenders must be competitive to the incumbents, the banks. They may reduce the price of their loans to distant borrowers to do that, but the fact that originator-borrower distance is salient for loan performance implies that non-bank lenders ignore it at their peril.

Our findings are robust to using nearest bank branch rather than head office for the bank location, to the incorporation of borrower-property distance, and to the incorporation of a post-crisis variable. 


\section{Figures and Tables}

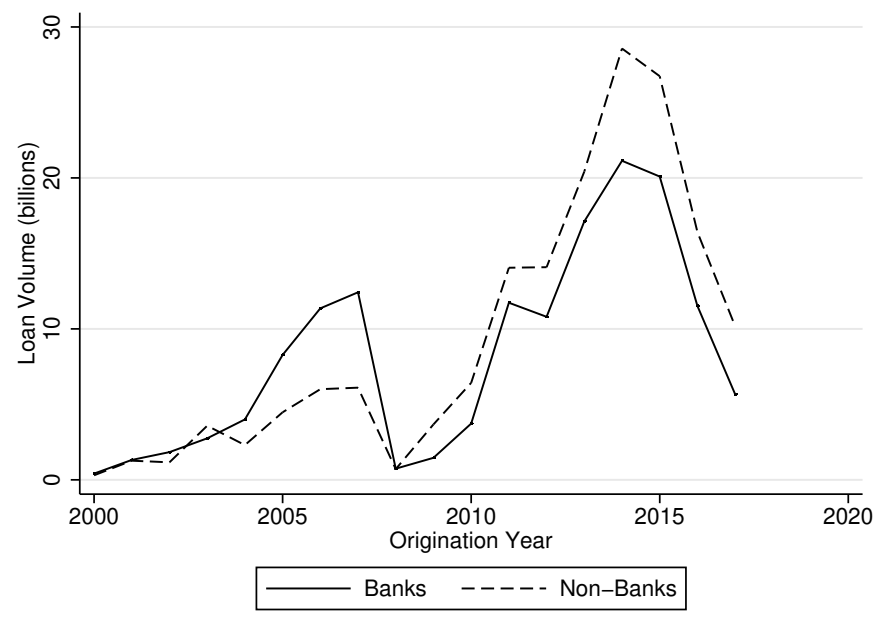

FIGURE 2.1: Distribution of Loan Volumes Originated by Years. 


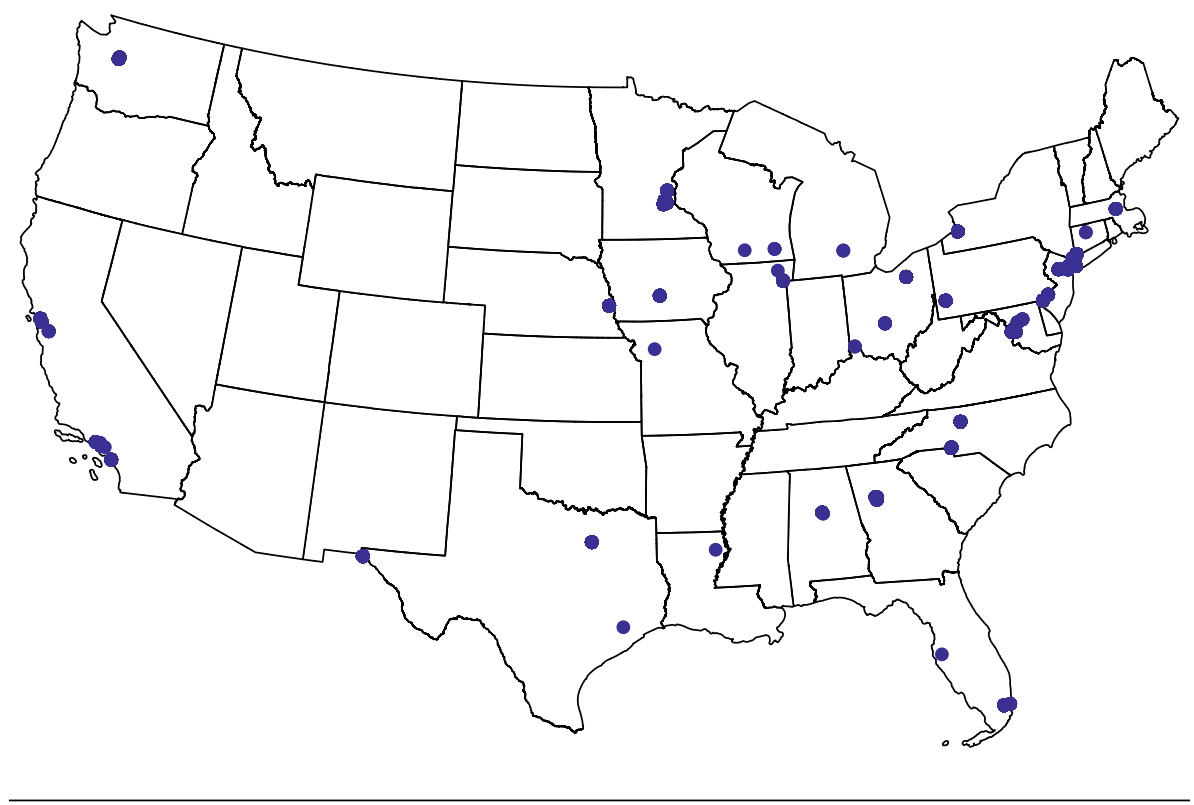

FIGURE 2.2: Distribution of Lender Headquarters.

The map shows the headquarters of the 100 lenders we observe in our sample between 2000:Q1 and 2017:Q3. Alaska and Hawaii are not shown. 


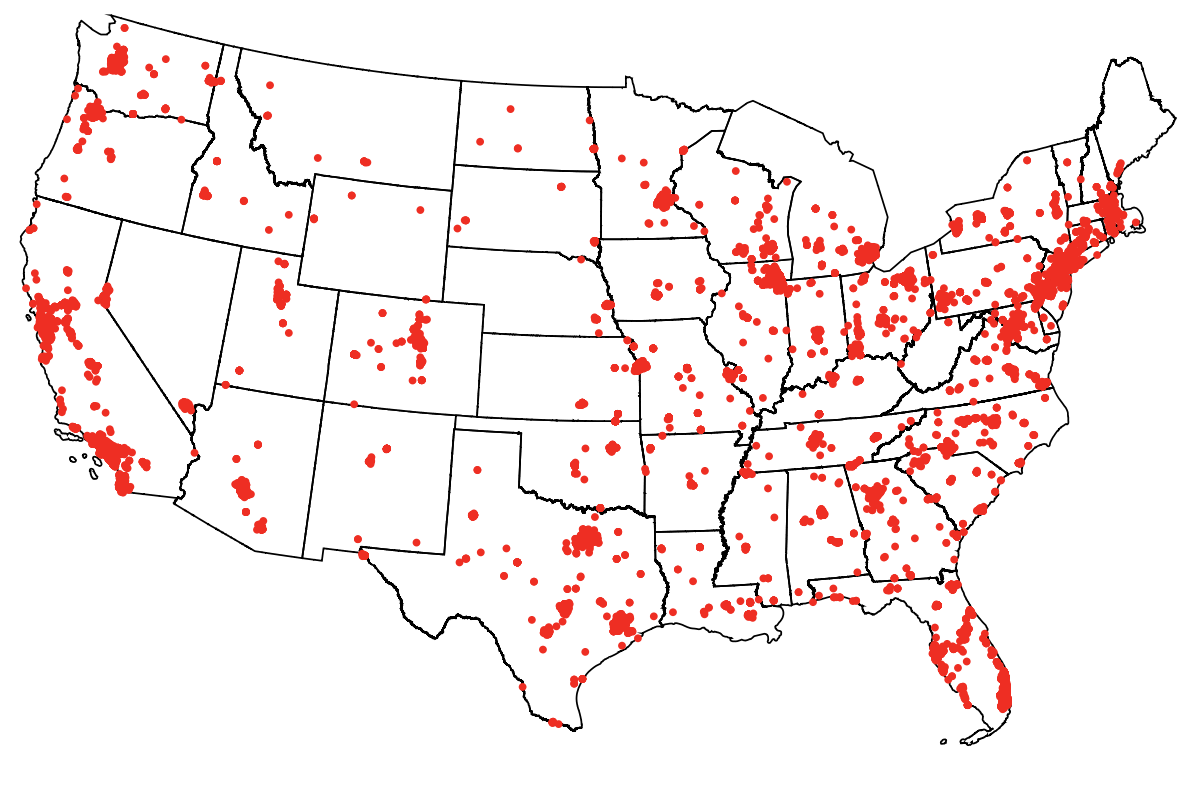

FIGURE 2.3: Distribution of Borrowers.

The map shows the location of the 8,510 unique borrowers we observe in our sample between 2000:Q1 and 2017:Q3. Alaska and Hawaii are not shown. 


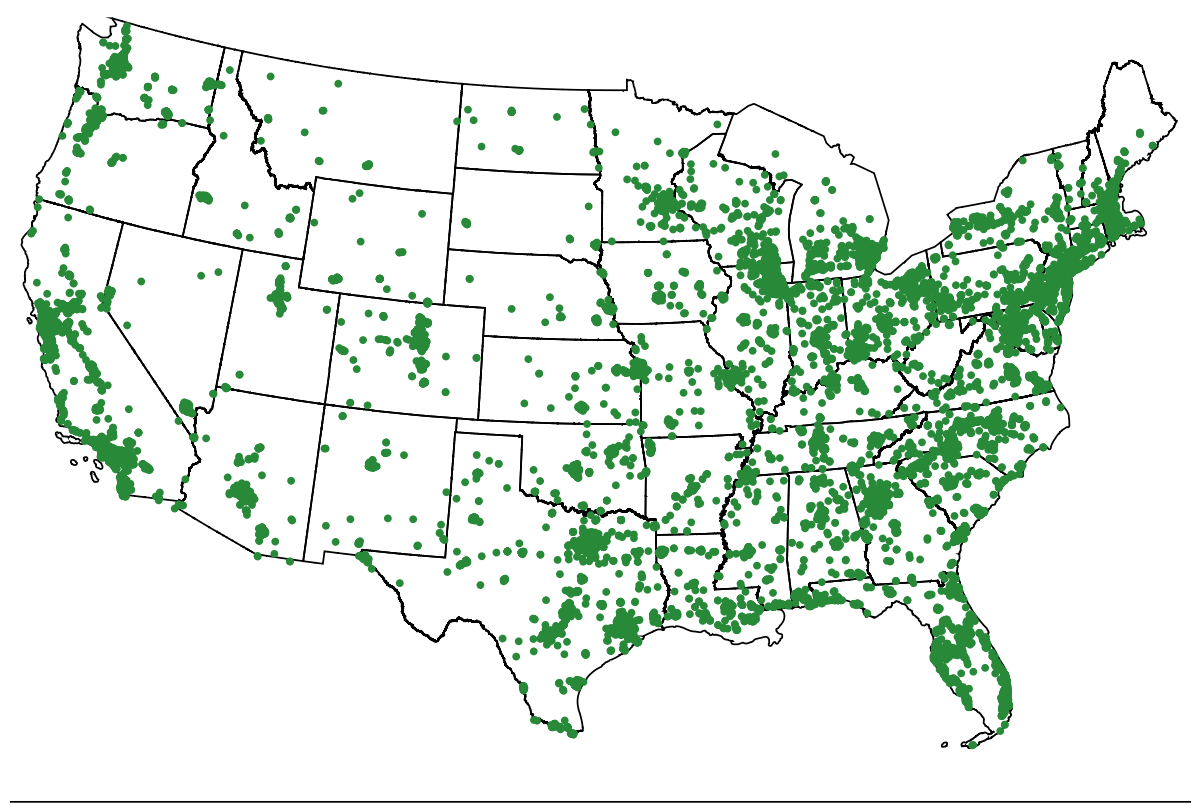

FIGURE 2.4: Distribution of Properties.

The map shows the location of the 24,812 unique properties we observe in our bank subsample between 2000:Q1 and 2017:Q3. Alaska and Hawaii are not shown. 


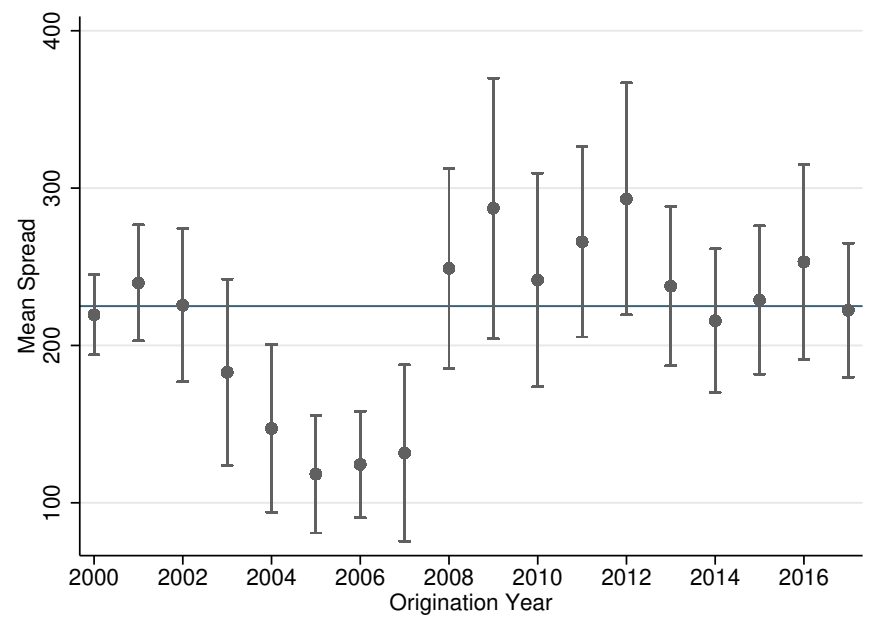

FIGURE 2.5: Spread by Years.

The graph shows the average loan spread over time, plus and minus one standard deviation. For each year, the dot depicts the mean spread, and the bar shows the plus and minus one standard deviation range. Blue line shows the average spread, $225 \mathrm{bps}$, for the whole sample period. 


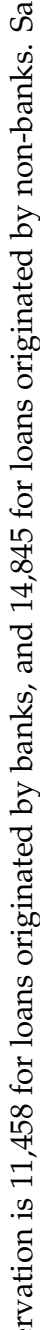

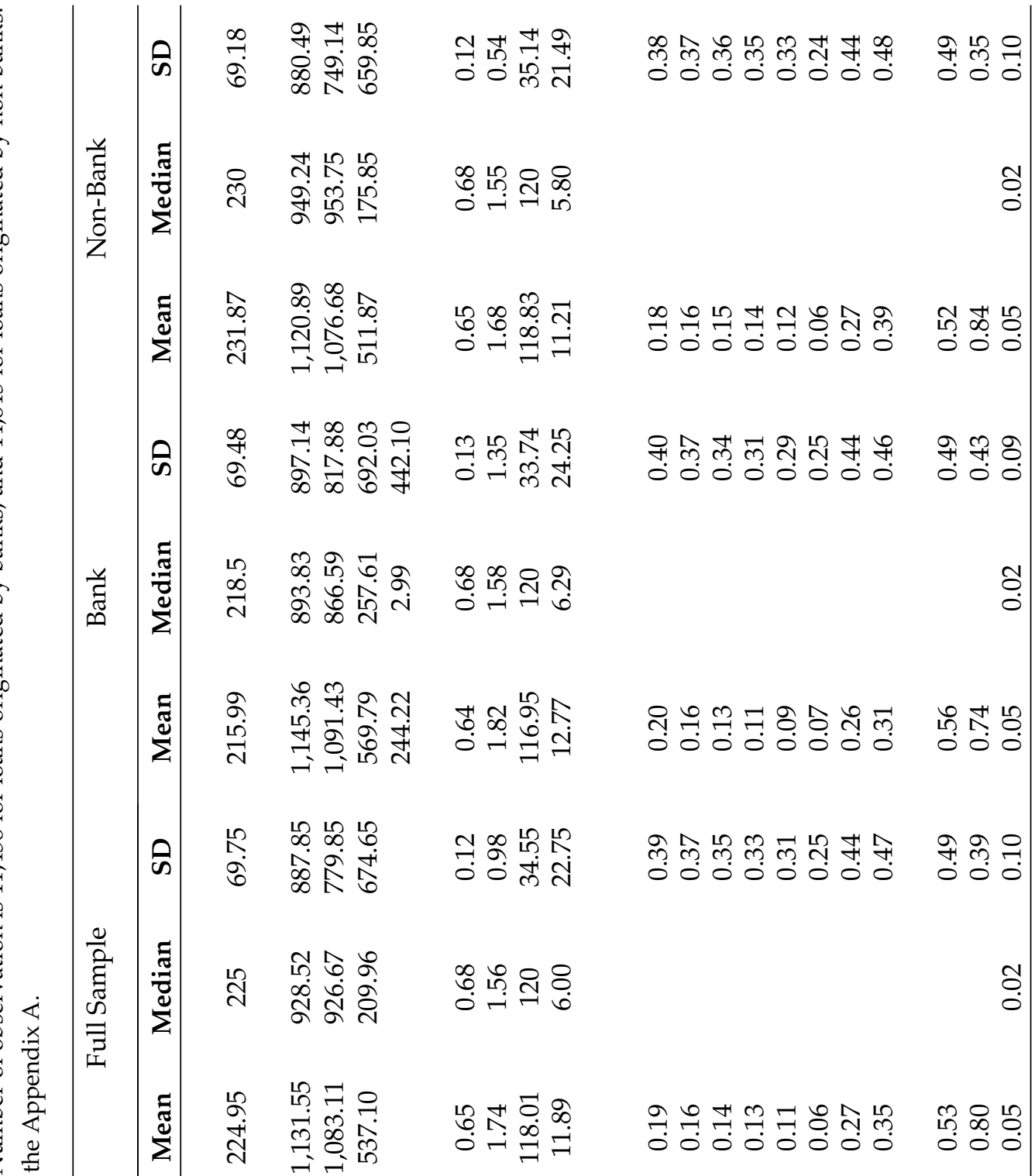


Table 2.2: Originator-Borrower Distance and Spread

Notes: This table reports OLS regression results. The dependent variable is the loan spread, between the mortgage rate and the Treasury bond rate with the same maturity, in basis points. Distance Originator-Borrower $_{\text {in }}$ is the geographic distance between originator headquarter and borrower, in miles. Control variables include indicator variables for age of the property, loan purpose, MSA, and state where the property is located. All variables are defined in the Appendix A. Robust standard errors, clustered at the MSA level, are in parentheses. ${ }^{* * *}, * *$, and ${ }^{*}$ denote significance at the $1 \%, 5 \%$, and $10 \%$ level, respectively.

Dependent variable: Spread
(1)
(2)
(3)
(4)
(5)
(6)

\begin{tabular}{|c|c|c|c|c|c|c|}
\hline & Full Sample & Full Sample & Bank & Bank & Non-Bank & Non-Bank \\
\hline Ln(1+Distance Originator-Borrower $)$ & $\begin{array}{c}1.705^{* * *} \\
(0.562)\end{array}$ & $\begin{array}{c}1.397^{* * *} \\
(0.529)\end{array}$ & $\begin{array}{c}2.648^{* * *} \\
(0.656)\end{array}$ & $\begin{array}{c}2.542^{* * *} \\
(0.666)\end{array}$ & $\begin{array}{c}1.074 \\
(0.959)\end{array}$ & $\begin{array}{c}1.257 \\
(0.891)\end{array}$ \\
\hline Ln(1+Maturity) & $\begin{array}{c}-55.478^{* * *} \\
(3.306)\end{array}$ & $\begin{array}{c}-61.900^{* * *} \\
(3.630)\end{array}$ & $\begin{array}{c}-49.335^{* * *} \\
(5.721)\end{array}$ & $\begin{array}{c}-51.463^{* * *} \\
(6.278)\end{array}$ & $\begin{array}{c}-69.755^{* * *} \\
(4.186)\end{array}$ & $\begin{array}{c}-74.625^{* * *} \\
(4.629)\end{array}$ \\
\hline Ln(Loan Size) & $\begin{array}{c}-5.034^{* * *} \\
(0.530)\end{array}$ & $\begin{array}{c}-4.990^{* * *} \\
(0.561)\end{array}$ & $\begin{array}{c}-4.492^{* * *} \\
(0.758)\end{array}$ & $\begin{array}{c}-4.573^{* * *} \\
(0.743)\end{array}$ & $\begin{array}{c}-4.680^{* * *} \\
(0.728)\end{array}$ & $\begin{array}{c}-4.582^{* * *} \\
(0.732)\end{array}$ \\
\hline Loan to Value Ratio & $\begin{array}{c}41.445^{* * *} \\
(6.211)\end{array}$ & & $\begin{array}{c}19.612^{* *} \\
(9.723)\end{array}$ & & $\begin{array}{c}31.521^{* * *} \\
(8.149)\end{array}$ & \\
\hline Debt Service Coverage Ratio & & $\begin{array}{c}-17.526^{* * *} \\
(2.412)\end{array}$ & & $\begin{array}{c}-12.438^{* * *} \\
(3.859)\end{array}$ & & $\begin{array}{c}-19.284^{* * *} \\
(2.457)\end{array}$ \\
\hline Ln(Herfindahl-Hirschman Index) & $\begin{array}{c}0.713 \\
(1.494)\end{array}$ & $\begin{array}{c}0.252 \\
(1.395)\end{array}$ & $\begin{array}{l}4.199 * * \\
(1.976)\end{array}$ & $\begin{array}{l}3.532^{*} \\
(1.931)\end{array}$ & $\begin{array}{l}-2.645 \\
(2.329)\end{array}$ & $\begin{array}{l}-2.292 \\
(2.168)\end{array}$ \\
\hline Number of Stories >1 & $\begin{array}{c}0.394 \\
(1.109)\end{array}$ & $\begin{array}{c}0.732 \\
(1.167)\end{array}$ & $\begin{array}{c}1.613 \\
(1.691)\end{array}$ & $\begin{array}{c}1.295 \\
(1.686)\end{array}$ & $\begin{array}{l}-0.658 \\
(1.252)\end{array}$ & $\begin{array}{l}-0.481 \\
(1.289)\end{array}$ \\
\hline Central Business District & $\begin{array}{c}0.545 \\
(2.235)\end{array}$ & $\begin{array}{l}-0.423 \\
(2.392)\end{array}$ & $\begin{array}{l}-4.100 \\
(3.132)\end{array}$ & $\begin{array}{l}-3.775 \\
(2.963)\end{array}$ & $\begin{array}{c}2.484 \\
(3.276)\end{array}$ & $\begin{array}{c}1.783 \\
(3.312)\end{array}$ \\
\hline Renovated & $\begin{array}{c}1.052 \\
(0.970)\end{array}$ & $\begin{array}{c}0.820 \\
(0.927)\end{array}$ & $\begin{array}{l}-0.616 \\
(1.219)\end{array}$ & $\begin{array}{l}-0.597 \\
(1.166)\end{array}$ & $\begin{array}{l}-0.022 \\
(1.269)\end{array}$ & $\begin{array}{l}-0.130 \\
(1.223)\end{array}$ \\
\hline Hotel & $\begin{array}{c}45.016^{* * *} \\
(5.343)\end{array}$ & $\begin{array}{c}53.051^{* * *} \\
(5.916)\end{array}$ & $\begin{array}{c}44.743^{* * *} \\
(10.095)\end{array}$ & $\begin{array}{c}50.732^{* * *} \\
(11.075)\end{array}$ & $\begin{array}{c}35.996^{* * *} \\
(9.651)\end{array}$ & $\begin{array}{c}39.012^{* * *} \\
(8.422)\end{array}$ \\
\hline Industrial & $\begin{array}{c}18.375^{* * *} \\
(3.701)\end{array}$ & $\begin{array}{c}14.910^{* * *} \\
(3.948)\end{array}$ & $\begin{array}{c}15.056^{* *} \\
(6.800)\end{array}$ & $\begin{array}{c}14.577^{* *} \\
(6.595)\end{array}$ & $\begin{array}{l}-1.569 \\
(5.252)\end{array}$ & $\begin{array}{c}0.589 \\
(5.223)\end{array}$ \\
\hline Office & $\begin{array}{c}13.992^{* * *} \\
(3.048)\end{array}$ & $\begin{array}{c}14.709^{* * *} \\
(3.149)\end{array}$ & $\begin{array}{c}11.552^{* *} \\
(4.488)\end{array}$ & $\begin{array}{c}12.982^{* * *} \\
(4.076)\end{array}$ & $\begin{array}{c}5.449 \\
(5.349)\end{array}$ & $\begin{array}{c}6.627 \\
(5.125)\end{array}$ \\
\hline Other & $\begin{array}{c}14.438^{* * *} \\
(3.628)\end{array}$ & $\begin{array}{c}15.359^{* * *} \\
(3.204)\end{array}$ & $\begin{array}{c}13.787^{* * *} \\
(4.178)\end{array}$ & $\begin{array}{c}14.426^{* * *} \\
(4.006)\end{array}$ & $\begin{array}{c}11.993^{* *} \\
(5.965)\end{array}$ & $\begin{array}{c}12.508^{* *} \\
(5.818)\end{array}$ \\
\hline Retail & $\begin{array}{c}15.878^{* * *} \\
(2.372)\end{array}$ & $\begin{array}{c}15.029^{* * *} \\
(2.454)\end{array}$ & $\begin{array}{c}23.523^{* * *} \\
(4.950)\end{array}$ & $\begin{array}{c}24.850^{* * *} \\
(5.228)\end{array}$ & $\begin{array}{l}-0.636 \\
(4.686)\end{array}$ & $\begin{array}{c}0.888 \\
(4.402)\end{array}$ \\
\hline Constant & $\begin{array}{c}463.889^{* * *} \\
(26.610)\end{array}$ & $\begin{array}{c}583.305^{* * *} \\
(30.531)\end{array}$ & $\begin{array}{c}435.580^{* * *} \\
(34.055)\end{array}$ & $\begin{array}{c}493.677^{* * *} \\
(51.283)\end{array}$ & $\begin{array}{c}441.359^{* * *} \\
(42.964)\end{array}$ & $\begin{array}{c}565.152^{* * *} \\
(50.655)\end{array}$ \\
\hline Control Variables & Yes & Yes & Yes & Yes & Yes & Yes \\
\hline Originator FE & Yes & Yes & Yes & Yes & Yes & Yes \\
\hline Borrower FE & Yes & Yes & Yes & Yes & Yes & Yes \\
\hline Year-quarter FE & Yes & Yes & Yes & Yes & Yes & Yes \\
\hline Observations & 25,508 & 25,098 & 10,999 & 10,736 & 14,509 & 14,362 \\
\hline Adjusted $R^{2}$ & 0.821 & 0.828 & 0.854 & 0.859 & 0.847 & 0.851 \\
\hline
\end{tabular}


Table 2.3: The Effect of Property Type

Notes: This table reports OLS regression results. The dependent variable is the loan spread, between the mortgage rate and the Treasury bond rate with the same maturity, in basis points. Distance Originator-Borrower is the geographic distance between originator headquarter and borrower, in miles. Control variables include indicator variables for age of the property, loan purpose, MSA, and state where the property is located. All variables are defined in the Appendix A. Robust standard errors, clustered at the MSA level, are in parentheses. ${ }^{* * *},{ }^{* *}$, and ${ }^{*}$ denote significance at the $1 \%, 5 \%$, and $10 \%$ level, respectively.

Dependent variable: Spread
(1)
(2)
(3)
(4)
(5)
(6)

Full Sample $\quad$ Full Sample Bank $\quad$ Bank Non-Bank Non-Bank

\begin{tabular}{|c|c|c|c|c|c|c|}
\hline $\operatorname{Ln}\left(1+\right.$ Distance $\left._{\text {Originator-Borrower }}\right)$ & $\begin{array}{l}-0.675 \\
(0.694)\end{array}$ & $\begin{array}{l}-0.591 \\
(0.649)\end{array}$ & $\begin{array}{l}-0.919 \\
(1.536)\end{array}$ & $\begin{array}{l}-1.068 \\
(1.487)\end{array}$ & $\begin{array}{c}0.338 \\
(1.192)\end{array}$ & $\begin{array}{c}0.600 \\
(1.085)\end{array}$ \\
\hline Hotel & 12.838 & $\begin{array}{c}30.318^{* * *} \\
(11206)\end{array}$ & $\begin{array}{c}42.415 \\
(26.107)\end{array}$ & $\begin{array}{l}46.970^{*} \\
(26.982)\end{array}$ & $\begin{array}{c}13.119 \\
\end{array}$ & 17.756 \\
\hline Industrial & $\begin{array}{c}(10.883) \\
-18.907^{* *} \\
(8.332)\end{array}$ & $\begin{array}{c}(11.206) \\
-15.412^{*} \\
(9.176)\end{array}$ & $\begin{array}{l}(26.107) \\
-24.156 \\
(15.742)\end{array}$ & $\begin{array}{l}(26.982) \\
-25.899 \\
(17.881)\end{array}$ & $\begin{array}{l}(17.393) \\
-21.306^{*} \\
(11.660)\end{array}$ & $\begin{array}{l}(14.276) \\
-17.118 \\
(10.962)\end{array}$ \\
\hline Office & $\begin{array}{l}-6.136 \\
(5.756)\end{array}$ & $\begin{array}{l}-4.339 \\
(6.111)\end{array}$ & $\begin{array}{c}-26.094^{* *} \\
(11.526)\end{array}$ & $\begin{array}{c}-25.173^{* *} \\
(11.415)\end{array}$ & $\begin{array}{c}-4.570 \\
(11.692)\end{array}$ & $\begin{array}{c}-2.747 \\
(10.898)\end{array}$ \\
\hline Other & $\begin{array}{c}10.793 \\
(12.783)\end{array}$ & $\begin{array}{c}7.972 \\
(11.678)\end{array}$ & $\begin{array}{l}-26.061 \\
(19.298)\end{array}$ & $\begin{array}{l}-27.300 \\
(17.997)\end{array}$ & $\begin{array}{c}5.268 \\
(18.242)\end{array}$ & $\begin{array}{l}-5.024 \\
(26.075)\end{array}$ \\
\hline Retail & $\begin{array}{l}-6.906 \\
(7.619)\end{array}$ & $\begin{array}{l}-6.033 \\
(7.141)\end{array}$ & $\begin{array}{c}-4.849 \\
(12.469)\end{array}$ & $\begin{array}{c}-4.170 \\
(11.735)\end{array}$ & $\begin{array}{c}-7.236 \\
(16.881)\end{array}$ & $\begin{array}{c}-2.136 \\
(16.194)\end{array}$ \\
\hline Hotel\#c.Ln $\left(1+\right.$ Distance $\left._{\text {Originator }- \text { Borrower }}\right)$ & $\begin{array}{c}5.526^{* * *} \\
(1.619)\end{array}$ & $\begin{array}{l}3.720^{* *} \\
(1.634)\end{array}$ & $\begin{array}{c}0.245 \\
(3.789)\end{array}$ & $\begin{array}{c}0.485 \\
(3.895)\end{array}$ & $\begin{array}{c}3.937 \\
(2.664)\end{array}$ & $\begin{array}{c}3.647 \\
(2.410)\end{array}$ \\
\hline Industrial\#c.Ln(1+Distance Originator - Borrower $)$ & $\begin{array}{c}6.167^{* * *} \\
(1.295)\end{array}$ & $\begin{array}{c}5.047^{* * *} \\
(1.405)\end{array}$ & $\begin{array}{l}6.496^{* *} \\
(2.639)\end{array}$ & $\begin{array}{l}6.749^{* *} \\
(2.982)\end{array}$ & $\begin{array}{l}3.435^{*} \\
(1.967)\end{array}$ & $\begin{array}{l}3.098^{*} \\
(1.769)\end{array}$ \\
\hline Office\#c.Ln(1+Distance Originator-Borrower $)$ & $\begin{array}{l}3.125^{* * *} \\
(1.061)\end{array}$ & $\begin{array}{c}2.999^{* * *} \\
(1.105)\end{array}$ & $\begin{array}{l}6.000^{* * *} \\
(1.629)\end{array}$ & $\begin{array}{l}6.094^{* * * *} \\
(1.669)\end{array}$ & $\begin{array}{c}1.608 \\
(1.854)\end{array}$ & $\begin{array}{c}1.534 \\
(1.696)\end{array}$ \\
\hline Other\#c.Ln(1+Distance $\left.{ }_{\text {Originator-Borrower }}\right)$ & $\begin{array}{c}0.649 \\
(1.902)\end{array}$ & $\begin{array}{l}1.240 \\
(1.780)\end{array}$ & $\begin{array}{l}5.982^{* *} \\
(2.687)\end{array}$ & $\begin{array}{l}6.245^{* *} \\
(2.501)\end{array}$ & $\begin{array}{c}1.105 \\
(2.746)\end{array}$ & $\begin{array}{c}2.783 \\
(3.925)\end{array}$ \\
\hline Retail\#c.Ln(1+Distance Originator-Borrower $)$ & $\begin{array}{c}3.592^{* * *} \\
(1.164)\end{array}$ & $\begin{array}{c}3.337^{* * *} \\
(1.094)\end{array}$ & $\begin{array}{l}4.456^{* *} \\
(1.887)\end{array}$ & $\begin{array}{l}4.579 * * \\
(1.819)\end{array}$ & $\begin{array}{c}1.150 \\
(2.384)\end{array}$ & $\begin{array}{c}0.607 \\
(2.312)\end{array}$ \\
\hline $\operatorname{Ln}(1+$ Maturity $)$ & $\begin{array}{c}-55.599^{* * *} \\
(3.285)\end{array}$ & $\begin{array}{c}-61.918^{* * *} \\
(3.622)\end{array}$ & $\begin{array}{c}-49.771^{* * *} \\
(5.825)\end{array}$ & $\begin{array}{c}-51.963^{* * *} \\
(6.421)\end{array}$ & $\begin{array}{c}-69.734^{* * *} \\
(4.191)\end{array}$ & $\begin{array}{c}-74.686^{* * *} \\
(4.661)\end{array}$ \\
\hline Ln(Loan Size) & $\begin{array}{c}-5.082^{* * *} \\
(0.510)\end{array}$ & $\begin{array}{c}-4.997^{* * *} \\
(0.546)\end{array}$ & $\begin{array}{c}-4.410^{* * *} \\
(0.751)\end{array}$ & $\begin{array}{c}-4.454^{* * *} \\
(0.734)\end{array}$ & $\begin{array}{c}-4.704^{* * *} \\
(0.734)\end{array}$ & $\begin{array}{c}-4.598^{* * *} \\
(0.733)\end{array}$ \\
\hline Loan to Value Ratio & $\begin{array}{c}40.230^{* * *} \\
(6.073)\end{array}$ & & $\begin{array}{c}21.391^{* *} \\
(9.479)\end{array}$ & & $\begin{array}{c}31.575^{* * *} \\
(8.090)\end{array}$ & \\
\hline Debt Service Coverage Ratio & & $\begin{array}{c}-17.190^{* * *} \\
(2.345)\end{array}$ & & $\begin{array}{c}-12.504^{* * *} \\
(3.901)\end{array}$ & & $\begin{array}{c}-19.300^{* * *} \\
(2.442)\end{array}$ \\
\hline Ln(Herfindahl-Hirschman Index) & $\begin{array}{c}0.484 \\
(1.482)\end{array}$ & $\begin{array}{c}0.078 \\
(1.381)\end{array}$ & $\begin{array}{l}3.838^{*} \\
(1.975)\end{array}$ & $\begin{array}{l}3.209^{*} \\
(1.926)\end{array}$ & $\begin{array}{l}-2.675 \\
(2.338)\end{array}$ & $\begin{array}{l}-2.312 \\
(2.183)\end{array}$ \\
\hline Number of Stories $>1$ & $\begin{array}{c}0.350 \\
(1.086)\end{array}$ & $\begin{array}{c}0.711 \\
(1.142)\end{array}$ & $\begin{array}{c}1.467 \\
(1.636)\end{array}$ & $\begin{array}{c}1.144 \\
(1.609)\end{array}$ & $\begin{array}{l}-0.719 \\
(1.260)\end{array}$ & $\begin{array}{l}-0.538 \\
(1.303)\end{array}$ \\
\hline Central Business District & $\begin{array}{l}-0.037 \\
(2.277)\end{array}$ & $\begin{array}{l}-0.876 \\
(2.447)\end{array}$ & $\begin{array}{l}-4.029 \\
(3.147)\end{array}$ & $\begin{array}{l}-3.798 \\
(2.996)\end{array}$ & $\begin{array}{c}2.423 \\
(3.271)\end{array}$ & $\begin{array}{c}1.708 \\
(3.305)\end{array}$ \\
\hline Renovated & $\begin{array}{c}1.056 \\
(0.942)\end{array}$ & $\begin{array}{c}0.807 \\
(0.903)\end{array}$ & $\begin{array}{c}-0.746 \\
(1.190)\end{array}$ & $\begin{array}{c}-0.721 \\
(1.121)\end{array}$ & $\begin{array}{l}-0.020 \\
(1.273)\end{array}$ & $\begin{array}{l}-0.138 \\
(1.222)\end{array}$ \\
\hline Constant & $\begin{array}{c}473.775^{* * *} \\
(26.753)\end{array}$ & $\begin{array}{c}586.720^{* * *} \\
(30.047)\end{array}$ & $\begin{array}{c}455.895^{* * *} \\
(35.215)\end{array}$ & $\begin{array}{c}514.266^{* * * *} \\
(53.312)\end{array}$ & $\begin{array}{c}444.308^{* * * *} \\
(43.100)\end{array}$ & $\begin{array}{c}568.988^{* * *} \\
(51.409)\end{array}$ \\
\hline Control Variables & Yes & Yes & Yes & Yes & Yes & Yes \\
\hline Originator FE & Yes & Yes & Yes & Yes & Yes & Yes \\
\hline Borrower FE & Yes & Yes & Yes & Yes & Yes & Yes \\
\hline Year-quarter FE & Yes & Yes & Yes & Yes & Yes & Yes \\
\hline Observations & $\begin{array}{c}25,508 \\
0822\end{array}$ & $\begin{array}{c}25,098 \\
0899\end{array}$ & $\begin{array}{l}10,999 \\
0855\end{array}$ & 10,736 & $\begin{array}{c}14,509 \\
0847\end{array}$ & 14,362 \\
\hline
\end{tabular}


Table 2.4: Borrower-Property Distance and Spread

Notes: This table reports OLS regression results. The dependent variable is the loan spread, between the mortgage rate and the Treasury bond rate with the same maturity, in basis points. Control variables include indicator variables for age of the property, loan purpose, property type, MSA, and state where the property is located. All variables are defined in the Appendix A. Robust standard errors, clustered at the MSA level, are in parentheses. ${ }^{* * *}, * *$, and ${ }^{*}$ denote significance at the $1 \%, 5 \%$, and $10 \%$ level, respectively.

\begin{tabular}{|c|c|c|c|c|c|c|}
\hline & \multicolumn{6}{|c|}{ Dependent variable: Spread } \\
\hline & $(1)$ & $(2)$ & (3) & $(4)$ & (5) & (6) \\
\hline & Full Sample & Full Sample & Bank & Bank & Non-Bank & Non-Bank \\
\hline $\begin{array}{l}\operatorname{Ln}\left(1+\text { Distance }_{\text {Originator-Property }}\right) \\
\text { when property is closer to originator than borrower is }\end{array}$ & $\begin{array}{c}0.723 \\
(0.547)\end{array}$ & $\begin{array}{c}0.594 \\
(0.472)\end{array}$ & $\begin{array}{c}0.555 \\
(0.749)\end{array}$ & $\begin{array}{c}0.517 \\
(0.710)\end{array}$ & $\begin{array}{l}1.169 \\
(0.806)\end{array}$ & $\begin{array}{l}1.323^{*} \\
(0.768)\end{array}$ \\
\hline $\begin{array}{l}\mathrm{Ln}(1+\text { Distance } \text { Originator-Borrower }) \\
\text { when borrower is closer to originator than property is }\end{array}$ & $\begin{array}{l}1.031^{*} \\
(0.541)\end{array}$ & $\begin{array}{l}0.850^{*} \\
(0.481)\end{array}$ & $\begin{array}{l}1.728^{* *} \\
(0.667)\end{array}$ & $\begin{array}{l}1.606^{* *} \\
(0.673)\end{array}$ & $\begin{array}{l}1.026 \\
(0.746)\end{array}$ & $\begin{array}{l}1.264^{*} \\
(0.699)\end{array}$ \\
\hline $\begin{array}{l}\mathrm{Ln}\left(1+\text { Distance }_{\text {Borrower-Property }}\right) \\
\text { when property is closer to originator than borrower is }\end{array}$ & $\begin{array}{l}0.913^{* *} \\
(0.428)\end{array}$ & $\begin{array}{l}0.787^{*} \\
(0.398)\end{array}$ & $\begin{array}{l}1.082^{*} \\
(0.558)\end{array}$ & $\begin{array}{l}0.971^{*} \\
(0.550)\end{array}$ & $\begin{array}{c}0.622 \\
(0.431)\end{array}$ & $\begin{array}{l}0.837^{*} \\
(0.427)\end{array}$ \\
\hline $\begin{array}{l}\operatorname{Ln}\left(1+\text { Distance }_{\text {Borrower-Property }}\right) \\
\text { when borrower is closer to originator than property is }\end{array}$ & $\begin{array}{l}-0.084 \\
(0.357)\end{array}$ & $\begin{array}{l}-0.038 \\
(0.347)\end{array}$ & $\begin{array}{c}-1.033^{* *} \\
(0.512)\end{array}$ & $\begin{array}{l}-1.008^{*} \\
(0.533)\end{array}$ & $\begin{array}{c}0.249 \\
(0.486)\end{array}$ & $\begin{array}{c}0.327 \\
(0.451)\end{array}$ \\
\hline Ln(1+Maturity) & $\begin{array}{l}-55.330^{* * *} \\
(3.276)\end{array}$ & $\begin{array}{l}-61.780^{* * *} \\
(3.607)\end{array}$ & $\begin{array}{l}-48.992^{* * *} \\
(5.690)\end{array}$ & $\begin{array}{l}-51.124^{* * *} \\
(6.244)\end{array}$ & $\begin{array}{l}-69.665^{* * *} \\
(4.170)\end{array}$ & $\begin{array}{l}-74.556^{* * *} \\
(4.613)\end{array}$ \\
\hline Ln(Loan Size) & $\begin{array}{l}-5.019^{* * *} \\
(0.525)\end{array}$ & $\begin{array}{c}-4.978^{* * *} \\
(0.558)\end{array}$ & $\begin{array}{l}-4.522^{* * *} \\
(0.744)\end{array}$ & $\begin{array}{l}-4.594^{* * *} \\
(0.733)\end{array}$ & $\begin{array}{l}-4.657^{* * *} \\
(0.728)\end{array}$ & $\begin{array}{l}-4.563^{* * *} \\
(0.732)\end{array}$ \\
\hline Loan to Value Ratio & $\begin{array}{c}41.538^{* * *} \\
(6.247)\end{array}$ & & $\begin{array}{c}20.607^{* *} \\
(9.632)\end{array}$ & & $\begin{array}{c}31.324^{* * *} \\
(8.112)\end{array}$ & \\
\hline Debt Service Coverage Ratio & & $\begin{array}{c}-17.533^{* * *} \\
(2.424)\end{array}$ & & $\begin{array}{c}-12.449^{* * *} \\
(3.866)\end{array}$ & & $\begin{array}{c}-19.319^{* * *} \\
(2.462)\end{array}$ \\
\hline Ln(Herfindahl-Hirschman Index) & $\begin{array}{c}0.767 \\
(1.506)\end{array}$ & $\begin{array}{c}0.292 \\
(1.402)\end{array}$ & $\begin{array}{l}4.237^{* *} \\
(1.988)\end{array}$ & $\begin{array}{l}3.534^{*} \\
(1.959)\end{array}$ & $\begin{array}{l}-2.579 \\
(2.311)\end{array}$ & $\begin{array}{l}-2.228 \\
(2.148)\end{array}$ \\
\hline Number of Stories $>1$ & $\begin{array}{c}0.397 \\
(1.106)\end{array}$ & $\begin{array}{c}0.732 \\
(1.165)\end{array}$ & $\begin{array}{c}1.753 \\
(1.673)\end{array}$ & $\begin{array}{c}1.420 \\
(1.672)\end{array}$ & $\begin{array}{l}-0.701 \\
(1.252)\end{array}$ & $\begin{array}{l}-0.520 \\
(1.290)\end{array}$ \\
\hline Central Business District & $\begin{array}{c}0.740 \\
(2.220)\end{array}$ & $\begin{array}{l}-0.256 \\
(2.369)\end{array}$ & $\begin{array}{l}-3.851 \\
(3.234)\end{array}$ & $\begin{array}{l}-3.528 \\
(3.054)\end{array}$ & $\begin{array}{c}2.477 \\
(3.296)\end{array}$ & $\begin{array}{l}1.826 \\
(3.322)\end{array}$ \\
\hline Renovated & $\begin{array}{c}1.026 \\
(0.969)\end{array}$ & $\begin{array}{c}0.801 \\
(0.924)\end{array}$ & $\begin{array}{c}-0.684 \\
(1.250)\end{array}$ & $\begin{array}{l}-0.673 \\
(1.203)\end{array}$ & $\begin{array}{l}-0.066 \\
(1.256)\end{array}$ & $\begin{array}{c}-0.174 \\
(1.211)\end{array}$ \\
\hline Hotel & $\begin{array}{c}44.924^{* * *} \\
(5.360)\end{array}$ & $\begin{array}{c}52.970^{* * *} \\
(5.910)\end{array}$ & $\begin{array}{c}44.096^{* * *} \\
(9.945)\end{array}$ & $\begin{array}{c}49.918^{* * *} \\
(10.933)\end{array}$ & $\begin{array}{c}35.986^{* * *} \\
(9.631)\end{array}$ & $\begin{array}{c}39.033^{* * *} \\
(8.378)\end{array}$ \\
\hline Industrial & $\begin{array}{c}18.286^{* * *} \\
(3.654)\end{array}$ & $\begin{array}{c}14.853^{* * *} \\
(3.907)\end{array}$ & $\begin{array}{c}15.100^{* *} \\
(6.634)\end{array}$ & $\begin{array}{c}14.436^{* *} \\
(6.454)\end{array}$ & $\begin{array}{l}-1.484 \\
(5.211)\end{array}$ & $\begin{array}{c}0.769 \\
(5.209)\end{array}$ \\
\hline Office & $\begin{array}{c}14.080^{* * *} \\
(3.013)\end{array}$ & $\begin{array}{c}14.805^{* * *} \\
(3.104)\end{array}$ & $\begin{array}{c}11.576^{* *} \\
(4.490)\end{array}$ & $\begin{array}{c}12.907^{* * *} \\
(4.077)\end{array}$ & $\begin{array}{l}5.610 \\
(5.326)\end{array}$ & $\begin{array}{c}6.890 \\
(5.109)\end{array}$ \\
\hline Other & $\begin{array}{c}14.391^{* * *} \\
(3.596)\end{array}$ & $\begin{array}{c}15.327^{* * *} \\
(3.190)\end{array}$ & $\begin{array}{c}13.921^{* * *} \\
(4.219)\end{array}$ & $\begin{array}{c}14.525^{* * *} \\
(4.054)\end{array}$ & $\begin{array}{c}11.842^{* *} \\
(5.973)\end{array}$ & $\begin{array}{c}12.314^{* *} \\
(5.809)\end{array}$ \\
\hline Retail & $\begin{array}{c}15.740^{* * *} \\
(2.356)\end{array}$ & $\begin{array}{c}14.927^{* * *} \\
(2.439)\end{array}$ & $\begin{array}{c}23.428^{* * *} \\
(4.929)\end{array}$ & $\begin{array}{c}24.691^{* * *} \\
(5.212)\end{array}$ & $\begin{array}{c}-0.641 \\
(4.722)\end{array}$ & $\begin{array}{c}0.886 \\
(4.465)\end{array}$ \\
\hline Constant & $\begin{array}{c}465.751^{* * *} \\
(26.518)\end{array}$ & $\begin{array}{c}585.078^{* * *} \\
(31.592)\end{array}$ & $\begin{array}{c}444.368^{* * *} \\
(34.081)\end{array}$ & $\begin{array}{c}503.693^{* * *} \\
(51.710)\end{array}$ & $\begin{array}{c}438.741^{* * *} \\
(42.471)\end{array}$ & $\begin{array}{c}563.104^{* * *} \\
(51.070)\end{array}$ \\
\hline Control Variables & Yes & Yes & Yes & Yes & Yes & Yes \\
\hline Originator FE & Yes & Yes & Yes & Yes & Yes & Yes \\
\hline Borrower FE & Yes & Yes & Yes & Yes & Yes & Yes \\
\hline Year-quarter FE & Yes & Yes & Yes & Yes & Yes & Yes \\
\hline $\begin{array}{l}\text { Observations } \\
\text { Adjusted } R^{2}\end{array}$ & $\begin{array}{c}25,508 \\
0.821\end{array}$ & $\begin{array}{c}25,098 \\
0.828\end{array}$ & $\begin{array}{c}10,999 \\
0.855\end{array}$ & $\begin{array}{c}10,736 \\
0.859\end{array}$ & $\begin{array}{c}14,509 \\
0.847\end{array}$ & $\begin{array}{c}14,362 \\
0.851\end{array}$ \\
\hline
\end{tabular}


Table 2.5: The Effect of Loan Size

Notes: This table reports OLS regression results. The dependent variable is the loan spread, between the mortgage rate and the Treasury bond rate with the same maturity, in basis points. Distance Originator-Borrower $_{\text {. }}$ is the geographic distance between originator headquarter and borrower, in miles. The indicator variable Small Loans equals one for the loans in the lower tercile, and zero otherwise. The indicator variable Large Loans equals one for the loans in the top tercile, and zero otherwise. Control variables include indicator variables for age of the property, loan purpose, property type, MSA, and state where the property is located. All variables are defined in the Appendix A. Robust standard errors, clustered at the MSA level, are in parentheses. ${ }^{* *},{ }^{* *}$, and ${ }^{*}$ denote significance at the $1 \%, 5 \%$, and $10 \%$ level, respectively.

\begin{tabular}{|c|c|c|c|c|c|c|}
\hline & \multicolumn{6}{|c|}{ Dependent variable: Spread } \\
\hline & $(1)$ & $(2)$ & (3) & $(4)$ & (5) & (6) \\
\hline & Full Sample & Full Sample & Bank & Bank & Non-Bank & Non-Bank \\
\hline Ln(1+Distance Originator-Borrower $)$ & $\begin{array}{c}1.779^{* * *} \\
(0.574)\end{array}$ & $\begin{array}{c}1.476^{* * *} \\
(0.547)\end{array}$ & $\begin{array}{c}2.855^{* * *} \\
(0.663)\end{array}$ & $\begin{array}{c}2.746^{* * *} \\
(0.674)\end{array}$ & $\begin{array}{l}1.234 \\
(0.972)\end{array}$ & $\begin{array}{c}1.417 \\
(0.895)\end{array}$ \\
\hline Small Loans\#c.Ln(1+Distance Originator-Borrower $)$ & $\begin{array}{c}0.446^{* * *} \\
(0.170)\end{array}$ & $\begin{array}{l}0.279^{*} \\
(0.151)\end{array}$ & $\begin{array}{c}0.180 \\
(0.260)\end{array}$ & $\begin{array}{c}0.162 \\
(0.260)\end{array}$ & $\begin{array}{c}0.248 \\
(0.212)\end{array}$ & $\begin{array}{c}0.135 \\
(0.208)\end{array}$ \\
\hline Large Loans\#c.Ln(1+Distance Originator-Borrower $)$ & $\begin{array}{c}-0.453^{* * *} \\
(0.168)\end{array}$ & $\begin{array}{c}-0.361^{* *} \\
(0.167)\end{array}$ & $\begin{array}{c}-0.568^{* *} \\
(0.239)\end{array}$ & $\begin{array}{c}-0.559^{* *} \\
(0.241)\end{array}$ & $\begin{array}{c}-0.466^{* *} \\
(0.224)\end{array}$ & $\begin{array}{c}-0.442^{* *} \\
(0.223)\end{array}$ \\
\hline Ln(1+Maturity) & $\begin{array}{l}-55.420^{* * * *} \\
(3.288)\end{array}$ & $\begin{array}{l}-61.810^{* * *} \\
(3.605)\end{array}$ & $\begin{array}{l}-49.092^{* * *} \\
(5.722)\end{array}$ & $\begin{array}{l}-51.215^{* * *} \\
(6.282)\end{array}$ & $\begin{array}{l}-69.684^{* * *} \\
(4.155)\end{array}$ & $\begin{array}{l}-74.562^{* * *} \\
(4.613)\end{array}$ \\
\hline Ln(Loan Size) & $\begin{array}{c}-3.467^{* * *} \\
(0.718)\end{array}$ & $\begin{array}{c}-3.866^{* * *} \\
(0.734)\end{array}$ & $\begin{array}{c}-3.188^{* * *} \\
(1.105)\end{array}$ & $\begin{array}{c}-3.311^{* * *} \\
(1.116)\end{array}$ & $\begin{array}{c}-3.472^{* * *} \\
(0.825)\end{array}$ & $\begin{array}{c}-3.599 * * * \\
(0.873)\end{array}$ \\
\hline Loan to Value Ratio & $\begin{array}{c}41.205^{* * *} \\
(6.221)\end{array}$ & & $\begin{array}{c}20.539^{* *} \\
(9.601)\end{array}$ & & $\begin{array}{c}30.990^{* * *} \\
(8.296)\end{array}$ & \\
\hline Debt Service Coverage Ratio & & $\begin{array}{c}-17.463^{* * *} \\
(2.399)\end{array}$ & & $\begin{array}{c}-12.473^{* * *} \\
(3.912)\end{array}$ & & $\begin{array}{c}-19.249^{* * *} \\
(2.455)\end{array}$ \\
\hline Ln(Herfindahl-Hirschman Index) & $\begin{array}{c}0.641 \\
(1.493)\end{array}$ & $\begin{array}{c}0.205 \\
(1.393)\end{array}$ & $\begin{array}{l}4.125^{* *} \\
(1.973)\end{array}$ & $\begin{array}{l}3.448^{*} \\
(1.935)\end{array}$ & $\begin{array}{l}-2.668 \\
(2.337)\end{array}$ & $\begin{array}{l}-2.293 \\
(2.171)\end{array}$ \\
\hline Number of Stories $>1$ & $\begin{array}{c}0.457 \\
(1.103)\end{array}$ & $\begin{array}{c}0.775 \\
(1.162)\end{array}$ & $\begin{array}{c}1.653 \\
(1.678)\end{array}$ & $\begin{array}{c}1.330 \\
(1.675)\end{array}$ & $\begin{array}{c}-0.593 \\
(1.251)\end{array}$ & $\begin{array}{c}-0.429 \\
(1.286)\end{array}$ \\
\hline Central Business District & $\begin{array}{c}0.348 \\
(2.245)\end{array}$ & $\begin{array}{l}-0.527 \\
(2.393)\end{array}$ & $\begin{array}{l}-3.895 \\
(3.124)\end{array}$ & $\begin{array}{l}-3.594 \\
(2.945)\end{array}$ & $\begin{array}{c}2.337 \\
(3.291)\end{array}$ & $\begin{array}{c}1.699 \\
(3.320)\end{array}$ \\
\hline Renovated & $\begin{array}{c}1.118 \\
(0.963)\end{array}$ & $\begin{array}{c}0.872 \\
(0.923)\end{array}$ & $\begin{array}{c}-0.557 \\
(1.212)\end{array}$ & $\begin{array}{c}-0.537 \\
(1.155)\end{array}$ & $\begin{array}{c}0.017 \\
(1.267)\end{array}$ & $\begin{array}{c}-0.094 \\
(1.221)\end{array}$ \\
\hline Hotel & $\begin{array}{c}45.231^{* * *} \\
(5.287)\end{array}$ & $\begin{array}{c}53.108^{* * *} \\
(5.902)\end{array}$ & $\begin{array}{c}44.109^{* * *} \\
(9.982)\end{array}$ & $\begin{array}{c}50.133^{* * *} \\
(10.981)\end{array}$ & $\begin{array}{c}36.112^{* * *} \\
(9.648)\end{array}$ & $\begin{array}{c}39.144^{* * *} \\
(8.420)\end{array}$ \\
\hline Industrial & $\begin{array}{c}18.387^{* * *} \\
(3.606)\end{array}$ & $\begin{array}{c}14.909 * * * \\
(3.885)\end{array}$ & $\begin{array}{c}15.189^{* *} \\
(6.795)\end{array}$ & $\begin{array}{c}14.639^{* *} \\
(6.604)\end{array}$ & $\begin{array}{l}-1.353 \\
(5.183)\end{array}$ & $\begin{array}{c}0.749 \\
(5.131)\end{array}$ \\
\hline Office & $\begin{array}{c}13.818^{* * *} \\
(3.022)\end{array}$ & $\begin{array}{c}14.569^{* * *} \\
(3.127)\end{array}$ & $\begin{array}{c}11.348^{* *} \\
(4.480)\end{array}$ & $\begin{array}{c}12.799^{* * *} \\
(4.065)\end{array}$ & $\begin{array}{c}5.463 \\
(5.297)\end{array}$ & $\begin{array}{c}6.624 \\
(5.056)\end{array}$ \\
\hline Other & $\begin{array}{c}14.157^{* * *} \\
(3.606)\end{array}$ & $\begin{array}{c}15.168^{* * *} \\
(3.214)\end{array}$ & $\begin{array}{c}13.693^{* * *} \\
(4.184)\end{array}$ & $\begin{array}{c}14.342^{* * *} \\
(4.032)\end{array}$ & $\begin{array}{l}11.593^{*} \\
(5.969)\end{array}$ & $\begin{array}{c}12.199^{* *} \\
(5.820)\end{array}$ \\
\hline Retail & $\begin{array}{c}15.783^{* * *} \\
(2.363)\end{array}$ & $\begin{array}{c}14.966^{* * *} \\
(2.436)\end{array}$ & $\begin{array}{c}23.404^{* * *} \\
(4.922)\end{array}$ & $\begin{array}{c}24.739^{* * *} \\
(5.189)\end{array}$ & $\begin{array}{l}-0.706 \\
(4.689)\end{array}$ & $\begin{array}{c}0.823 \\
(4.397)\end{array}$ \\
\hline Constant & $\begin{array}{c}440.622^{* * *} \\
(26.190)\end{array}$ & $\begin{array}{c}565.776^{* * *} \\
(29.016)\end{array}$ & $\begin{array}{c}396.396^{* * *} \\
(31.042)\end{array}$ & $\begin{array}{c}453.437^{* * *} \\
(48.320)\end{array}$ & $\begin{array}{c}421.956^{* * *} \\
(41.385)\end{array}$ & $\begin{array}{c}550.232^{* * *} \\
(49.426)\end{array}$ \\
\hline Control Variables & Yes & Yes & Yes & Yes & Yes & Yes \\
\hline Originator FE & Yes & Yes & Yes & Yes & Yes & Yes \\
\hline Borrower FE & Yes & Yes & Yes & Yes & Yes & Yes \\
\hline Year-quarter FE & Yes & Yes & Yes & Yes & Yes & Yes \\
\hline Observations & 25,508 & 25,098 & 10,999 & 10,736 & 14,509 & 14,362 \\
\hline Adjusted $R^{2}$ & 0.821 & 0.828 & 0.855 & 0.859 & 0.847 & 0.851 \\
\hline
\end{tabular}


Table 2.6: The Effect of the 2008 Financial Crisis

Notes: This table reports OLS regression results. The dependent variable is the loan spread, between the mortgage rate and Treasury bond rate with the same maturity, in basis points. Distance Originator-Borrower is the geographic distance between originator headquarter and borrower, in miles. The indicator variable Postcrisis equals one for the loans originated after the year 2009, and zero otherwise. Control variables include indicator variables for age of the property, loan purpose, property type, MSA, and state where the property is located. All variables are defined in the Appendix A. Robust standard errors, clustered at the MSA level, are in parentheses. ${ }^{* * *}, * *$, and ${ }^{*}$ denote significance at the $1 \%, 5 \%$, and $10 \%$ level, respectively.

Dependent variable: Spread

(1)

(2)

(3)

(4)

(5)

(6)

Full Sample Full Sample $\quad$ Bank $\quad$ Bank Non-Bank Non-Bank

\begin{tabular}{|c|c|c|c|c|c|c|}
\hline $\operatorname{Ln}\left(1+\right.$ Distance $\left._{\text {Originator-Borrower }}\right)$ & $\begin{array}{c}1.777 \\
(1.168)\end{array}$ & $\begin{array}{c}2.044 \\
(1.292)\end{array}$ & $\begin{array}{l}3.332^{* *} \\
(1.358)\end{array}$ & $\begin{array}{l}3.747^{* *} \\
(1.563)\end{array}$ & $\begin{array}{l}-0.292 \\
(2.044)\end{array}$ & $\begin{array}{c}0.362 \\
(2.107)\end{array}$ \\
\hline Postcrisis & $\begin{array}{c}66.528^{* * *} \\
(16.287)\end{array}$ & $\begin{array}{l}56.047^{* *} \\
(27.329)\end{array}$ & $\begin{array}{c}76.190^{* * *} \\
(19.865)\end{array}$ & $\begin{array}{l}67.954^{*} \\
(40.012)\end{array}$ & $\begin{array}{c}37.642 \\
(32.723)\end{array}$ & $\begin{array}{c}59.315 \\
(40.805)\end{array}$ \\
\hline Postcrisis\#c.Ln(1+Distance $\left.{ }_{\text {Originator-Borrower }}\right)$ & $\begin{array}{c}-0.090 \\
(1.203)\end{array}$ & $\begin{array}{l}-0.793 \\
(1.319)\end{array}$ & $\begin{array}{l}-0.907 \\
(1.582)\end{array}$ & $\begin{array}{l}-1.563 \\
(1.731)\end{array}$ & $\begin{array}{c}1.673 \\
(2.084)\end{array}$ & $\begin{array}{c}1.072 \\
(2.142)\end{array}$ \\
\hline $\operatorname{Ln}(1+$ Maturity $)$ & $\begin{array}{c}-55.482^{* * *} \\
(3.321)\end{array}$ & $\begin{array}{c}-61.961^{* * *} \\
(3.669)\end{array}$ & $\begin{array}{c}-49.319^{* * *} \\
(5.721)\end{array}$ & $\begin{array}{c}-51.431^{* * *} \\
(6.284)\end{array}$ & $\begin{array}{c}-69.655^{* * *} \\
(4.193)\end{array}$ & $\begin{array}{c}-74.537^{* * *} \\
(4.662)\end{array}$ \\
\hline Ln(Loan Size) & $\begin{array}{c}-5.034^{* * *} \\
(0.530)\end{array}$ & $\begin{array}{c}-4.992^{* * *} \\
(0.563)\end{array}$ & $\begin{array}{c}-4.500^{* * *} \\
(0.758)\end{array}$ & $\begin{array}{c}-4.585^{* * *} \\
(0.745)\end{array}$ & $\begin{array}{c}-4.680^{* * *} \\
(0.727)\end{array}$ & $\begin{array}{c}-4.580^{* * *} \\
(0.732)\end{array}$ \\
\hline Loan to Value Ratio & $\begin{array}{c}41.455^{* * *} \\
(6.171)\end{array}$ & & $\begin{array}{c}19.509^{* *} \\
(9.721)\end{array}$ & & $\begin{array}{c}31.483^{* * *} \\
(8.175)\end{array}$ & \\
\hline Debt Service Coverage Ratio & & $\begin{array}{c}-17.545^{* * *} \\
(2.439)\end{array}$ & & $\begin{array}{c}-12.445^{* * *} \\
(3.857)\end{array}$ & & $\begin{array}{c}-19.270^{* * *} \\
(2.468)\end{array}$ \\
\hline Ln(Herfindahl-Hirschman Index) & $\begin{array}{c}0.706 \\
(1.498)\end{array}$ & $\begin{array}{c}0.187 \\
(1.397)\end{array}$ & $\begin{array}{l}4.076^{* *} \\
(1.959)\end{array}$ & $\begin{array}{l}3.311^{*} \\
(1.890)\end{array}$ & $\begin{array}{l}-2.579 \\
(2.332)\end{array}$ & $\begin{array}{l}-2.249 \\
(2.172)\end{array}$ \\
\hline Number of Stories >1 & $\begin{array}{c}0.396 \\
(1.116)\end{array}$ & $\begin{array}{c}0.745 \\
(1.173)\end{array}$ & $\begin{array}{c}1.613 \\
(1.693)\end{array}$ & $\begin{array}{c}1.296 \\
(1.688)\end{array}$ & $\begin{array}{l}-0.656 \\
(1.251)\end{array}$ & $\begin{array}{c}-0.482 \\
(1.290)\end{array}$ \\
\hline Central Business District & $\begin{array}{c}0.549 \\
(2.237)\end{array}$ & $\begin{array}{l}-0.398 \\
(2.407)\end{array}$ & $\begin{array}{l}-4.026 \\
(3.093)\end{array}$ & $\begin{array}{l}-3.660 \\
(2.914)\end{array}$ & $\begin{array}{c}2.394 \\
(3.289)\end{array}$ & $\begin{array}{c}1.734 \\
(3.325)\end{array}$ \\
\hline Renovated & $\begin{array}{c}1.052 \\
(0.968)\end{array}$ & $\begin{array}{c}0.823 \\
(0.930)\end{array}$ & $\begin{array}{l}-0.630 \\
(1.229)\end{array}$ & $\begin{array}{c}-0.598 \\
(1.164)\end{array}$ & $\begin{array}{l}-0.015 \\
(1.271)\end{array}$ & $\begin{array}{l}-0.130 \\
(1.226)\end{array}$ \\
\hline Hotel & $\begin{array}{c}44.999^{* * *} \\
(5.354)\end{array}$ & $\begin{array}{c}52.989^{* * *} \\
(5.888)\end{array}$ & $\begin{array}{c}44.828^{* * *} \\
(10.161)\end{array}$ & $\begin{array}{c}50.873^{* * *} \\
(11.114)\end{array}$ & $\begin{array}{c}35.624^{* * *} \\
(9.643)\end{array}$ & $\begin{array}{c}38.766^{* * *} \\
(8.415)\end{array}$ \\
\hline Industrial & $\begin{array}{c}18.400^{* * *} \\
(3.749)\end{array}$ & $\begin{array}{c}15.107^{* * *} \\
(3.970)\end{array}$ & $\begin{array}{c}15.082^{* *} \\
(6.810)\end{array}$ & $\begin{array}{c}14.569^{* *} \\
(6.596)\end{array}$ & $\begin{array}{l}-1.581 \\
(5.275)\end{array}$ & $\begin{array}{c}0.525 \\
(5.257)\end{array}$ \\
\hline Office & $\begin{array}{c}14.005^{* * *} \\
(3.033)\end{array}$ & $\begin{array}{c}14.826^{* * * *} \\
(3.139)\end{array}$ & $\begin{array}{c}11.662^{* *} \\
(4.545)\end{array}$ & $\begin{array}{c}13.177^{* * *} \\
(4.140)\end{array}$ & $\begin{array}{l}5.479 \\
(5.374)\end{array}$ & $\begin{array}{l}6.614 \\
(5.141)\end{array}$ \\
\hline Other & $\begin{array}{c}14.459^{* * *} \\
(3.602)\end{array}$ & $\begin{array}{c}15.484^{* * *} \\
(3.197)\end{array}$ & $\begin{array}{c}14.021^{* * *} \\
(4.269)\end{array}$ & $\begin{array}{c}14.818^{* * *} \\
(4.053)\end{array}$ & $\begin{array}{c}12.086^{* *} \\
(5.956)\end{array}$ & $\begin{array}{c}12.626^{* *} \\
(5.815)\end{array}$ \\
\hline Retail & $\begin{array}{c}15.883^{* * *} \\
(2.375)\end{array}$ & $\begin{array}{c}15.074^{* * *} \\
(2.457)\end{array}$ & $\begin{array}{c}23.461^{* * *} \\
(4.899)\end{array}$ & $\begin{array}{c}24.768^{* * *} \\
(5.174)\end{array}$ & $\begin{array}{l}-0.639 \\
(4.705)\end{array}$ & $\begin{array}{c}0.852 \\
(4.421)\end{array}$ \\
\hline Constant & $\begin{array}{c}379.803^{* * *} \\
(26.470)\end{array}$ & $\begin{array}{c}579.835^{* * *} \\
(30.330)\end{array}$ & $\begin{array}{c}430.807^{* * *} \\
(36.246)\end{array}$ & $\begin{array}{c}485.470^{* * *} \\
(54.432)\end{array}$ & $\begin{array}{c}451.280^{* * *} \\
(42.213)\end{array}$ & $\begin{array}{c}571.130^{* * * *} \\
(50.274)\end{array}$ \\
\hline Control Variables & Yes & Yes & Yes & Yes & Yes & Yes \\
\hline Originator FE & Yes & Yes & Yes & Yes & Yes & Yes \\
\hline Borrower FE & Yes & Yes & Yes & Yes & Yes & Yes \\
\hline Year-quarter FE & Yes & Yes & Yes & Yes & Yes & Yes \\
\hline $\begin{array}{l}\text { Observations } \\
\text { Adjusted } R^{2}\end{array}$ & $\begin{array}{c}25,508 \\
0.821\end{array}$ & $\begin{array}{c}25,098 \\
0.828\end{array}$ & $\begin{array}{c}10,999 \\
0.854\end{array}$ & $\begin{array}{c}10,736 \\
0.859\end{array}$ & $\begin{array}{c}14,509 \\
0.847\end{array}$ & $\begin{array}{c}14,362 \\
0.851\end{array}$ \\
\hline
\end{tabular}


Table 2.7: Default Analysis

Notes: This table reports the estimation results of Cox proportional hazards models explaining loan default. The indicator variable Loan Default equals one when the mortgage is classified either "resolved,"'"restructured/extension" and "troubled," and zero otherwise. For each variable, we present the hazard ratio. Distance $_{\text {Originator-Borrower }}$ is the geographic distance between originator headquarter and borrower, in miles. Control variables include indicator variables for age of the property, loan purpose, property type, MSA, and state where the property is located. All variables are defined in the Appendix A. Robust standard errors, clustered at the MSA level, are in parentheses. ${ }^{* * *}, * *$, and ${ }^{*}$ denote significance at the $1 \%, 5 \%$, and $10 \%$ level, respectively.

Dependent variable: Loan Default

(1)

(2)

(3)

(4)

Full Sample Bank Bank-Branch Non-Bank

$\begin{array}{lcccc}\text { Ln(1+Distance } & \text { Originator-Borrower } \\ & 1.010 & 0.965 & & 1.117^{* *} \\ \text { Ln(1+Distance } & (0.024) & (0.028) & & (0.061) \\ & & & 1.084^{* * *} & \\ \text { Spranch-Borrower } & & & (0.027) & \\ & & & 0.984^{* * *} & 0.981^{* * *} \\ \text { Ln(1+Maturity) } & 0.984^{* * *} & 0.986^{* * *} & (0.001) & (0.002) \\ & (0.001) & (0.001) & (0.09)^{* * *} & 0.066^{* * *} \\ \text { Ln(Loan Size) } & 0.229^{* * *} & 0.324^{* * *} & 0.294^{* * *} & (0.022) \\ & (0.030) & (0.049) & (0.054) & 0.878^{* *} \\ \text { Loan to Value Ratio }>75 & 1.007 & 1.110^{* *} & 1.083 & (0.058) \\ & (0.041) & (0.054) & (0.066) & 4.623^{* * *} \\ \text { Number of Stories }>1 & 3.472^{* * *} & 3.207^{* * *} & 3.379^{* * *} & (1.359) \\ & (0.545) & (0.490) & (0.626) & 0.642^{*} \\ \text { Central Business District } & 0.926 & 1.074 & 1.151 & (0.165) \\ & (0.116) & (0.135) & (0.172) & 1.096 \\ \text { Renovated } & 0.925 & 0.883 & 0.828 & (0.403) \\ & (0.230) & (0.292) & (0.244) & 1.334^{*} \\ & 1.200^{* *} & 1.024 & 1.047 & (0.212)\end{array}$

\begin{tabular}{lllll}
\hline Observations & 25,508 & 10,999 & 10,337 & 14,509 \\
\hline
\end{tabular}


Table 2.8: Bank Branch-Borrower Distance and Spread

Notes: This table reports OLS regression results. The dependent variable is the loan spread, between the mortgage rate and Treasury bond rate with the same maturity, in basis points. Distance Branch-Borrower $_{\text {B }}$ is the geographic distance between nearest bank branch and borrower, in miles. Control variables include indicator variables for age of the property, loan purpose, MSA, and state where the property is located. All variables are defined in the Appendix A. Robust standard errors, clustered at the MSA level, are in parentheses. ${ }^{* * *}, * *$, and ${ }^{*}$ denote significance at the $1 \%, 5 \%$, and $10 \%$ level, respectively.

\begin{tabular}{|c|c|c|c|c|}
\hline & \multicolumn{4}{|c|}{ Dependent variable: Spread } \\
\hline & $(1)$ & (2) & (3) & (4) \\
\hline $\operatorname{Ln}\left(1+\right.$ Distance $\left._{\text {Branch-Borrower }}\right)$ & $\begin{array}{l}1.734^{* *} \\
(0.819)\end{array}$ & $\begin{array}{c}1.274^{* * *} \\
(0.479)\end{array}$ & $\begin{array}{c}1.587^{* * *} \\
(0.595)\end{array}$ & $\begin{array}{c}1.622^{* * *} \\
(0.581)\end{array}$ \\
\hline Ln(1+Maturity) & & $\begin{array}{c}-53.063^{* * *} \\
(5.788)\end{array}$ & $\begin{array}{c}-52.291^{* * *} \\
(5.755)\end{array}$ & $\begin{array}{c}-53.977^{* * *} \\
(6.326)\end{array}$ \\
\hline Ln(Loan Size) & & $\begin{array}{c}-4.544^{* * *} \\
(0.773)\end{array}$ & $\begin{array}{c}-4.541^{* * * *} \\
(0.746)\end{array}$ & $\begin{array}{c}-4.718^{* * *} \\
(0.726)\end{array}$ \\
\hline Loan to Value Ratio & & $\begin{array}{c}10.363 \\
(10.144)\end{array}$ & $\begin{array}{c}14.641 \\
(10.124)\end{array}$ & \\
\hline Debt Service Coverage Ratio & & & & $\begin{array}{c}-11.714^{* * *} \\
(3.804)\end{array}$ \\
\hline Ln(Herfindahl-Hirschman Index) & & $\begin{array}{l}5.005^{* *} \\
(2.184)\end{array}$ & $\begin{array}{l}4.056^{*} \\
(2.148)\end{array}$ & $\begin{array}{c}3.511 \\
(2.169)\end{array}$ \\
\hline Number of Stories $>1$ & & $\begin{array}{c}1.729 \\
(1.687)\end{array}$ & $\begin{array}{c}1.976 \\
(1.685)\end{array}$ & $\begin{array}{c}1.697 \\
(1.706)\end{array}$ \\
\hline Central Business District & & $\begin{array}{l}-5.088 \\
(3.116)\end{array}$ & $\begin{array}{l}-5.938^{*} \\
(3.021)\end{array}$ & $\begin{array}{l}-5.716^{* *} \\
(2.781)\end{array}$ \\
\hline Renovated & & $\begin{array}{c}0.112 \\
(1.411)\end{array}$ & $\begin{array}{c}-0.135 \\
(1.342)\end{array}$ & $\begin{array}{l}-0.154 \\
(1.316)\end{array}$ \\
\hline Hotel & & $\begin{array}{c}48.897^{* * *} \\
(10.329)\end{array}$ & $\begin{array}{c}41.699^{* * *} \\
(10.216)\end{array}$ & $\begin{array}{c}48.152^{* * *} \\
(11.229)\end{array}$ \\
\hline Industrial & & $\begin{array}{c}16.059^{* *} \\
(6.586)\end{array}$ & $\begin{array}{l}11.743^{*} \\
(6.699)\end{array}$ & $\begin{array}{l}11.547^{*} \\
(6.769)\end{array}$ \\
\hline Office & & $\begin{array}{c}17.178^{* * *} \\
(3.525)\end{array}$ & $\begin{array}{c}12.200^{* * *} \\
(3.948)\end{array}$ & $\begin{array}{c}13.962^{* * *} \\
(3.646)\end{array}$ \\
\hline Other & & $\begin{array}{c}20.482^{* * *} \\
(4.060)\end{array}$ & $\begin{array}{c}15.997^{* * *} \\
(4.115)\end{array}$ & $\begin{array}{c}16.748^{* * *} \\
(3.965)\end{array}$ \\
\hline Retail & & $\begin{array}{c}28.150^{* * * *} \\
(4.993)\end{array}$ & $\begin{array}{c}24.106^{* * *} \\
(5.072)\end{array}$ & $\begin{array}{c}25.433^{* * *} \\
(5.377)\end{array}$ \\
\hline Constant & $\begin{array}{c}212.610^{* * * *} \\
(2.523)\end{array}$ & $\begin{array}{c}491.921^{* * *} \\
(31.238)\end{array}$ & $\begin{array}{c}490.366^{* * *} \\
(30.307)\end{array}$ & $\begin{array}{c}531.718^{* * * *} \\
(32.399)\end{array}$ \\
\hline Control variables & No & Yes & Yes & Yes \\
\hline Bank FE & No & No & Yes & Yes \\
\hline Borrower FE & Yes & Yes & Yes & Yes \\
\hline Year-quarter FE & No & Yes & Yes & Yes \\
\hline Observations & 10,733 & 10,337 & 10,337 & 10,098 \\
\hline Adjusted $R^{2}$ & 0.551 & 0.854 & 0.858 & 0.862 \\
\hline
\end{tabular}


Table 2.9: Out-of-State Borrowers

Notes: This table reports OLS regression results. The dependent variable is the loan spread, between the mortgage rate and Treasury bond rate with the same maturity, in basis points. The indicator variable Out-of-State Borrower equals one if the borrower and property are located in different states, and zero otherwise. Control variables include indicator variables for age of the property, loan purpose, property type, MSA, and state where the property is located. All variables are defined in the Appendix A. Robust standard errors, clustered at the MSA level, are in parentheses. ${ }^{* * *}, * *$, and $*$ denote significance at the $1 \%, 5 \%$, and $10 \%$ level, respectively.

\begin{tabular}{|c|c|c|c|c|c|c|}
\hline & \multicolumn{6}{|c|}{ Dependent variable: Spread } \\
\hline & (1) & (2) & (3) & $(4)$ & (5) & (6) \\
\hline & Full Sample-First & Full Sample & Bank-First & Bank & Non-Bank-First & Non-Bank \\
\hline $\operatorname{Ln}\left(1+\right.$ Distance $\left._{\text {Originator-Borrower }}\right)$ & $\begin{array}{l}2.065^{* *} \\
(0.801)\end{array}$ & $\begin{array}{c}1.703^{* * *} \\
(0.562)\end{array}$ & $\begin{array}{l}3.513^{* *} \\
(1.456)\end{array}$ & $\begin{array}{c}2.671^{* * *} \\
(0.658)\end{array}$ & $\begin{array}{c}2.254 \\
(1.911)\end{array}$ & $\begin{array}{c}1.093 \\
(0.960)\end{array}$ \\
\hline Out-of-State Borrower & $\begin{array}{l}-0.402 \\
(1.512)\end{array}$ & $\begin{array}{c}0.507 \\
(1.338)\end{array}$ & $\begin{array}{l}-0.983 \\
(2.505)\end{array}$ & $\begin{array}{l}-2.152 \\
(1.658)\end{array}$ & $\begin{array}{c}1.833 \\
(3.322)\end{array}$ & $\begin{array}{c}1.319 \\
(1.950)\end{array}$ \\
\hline Ln(1+Maturity) & $\begin{array}{c}-58.551^{* * *} \\
(5.745)\end{array}$ & $\begin{array}{c}-55.455^{* * *} \\
(3.310)\end{array}$ & $\begin{array}{c}-55.933^{* * * *} \\
(8.599)\end{array}$ & $\begin{array}{c}-49.440^{* * * *} \\
(5.736)\end{array}$ & $\begin{array}{c}-59.937^{* * *} \\
(10.145)\end{array}$ & $\begin{array}{c}-69.704^{* * *} \\
(4.194)\end{array}$ \\
\hline Ln(Loan Size) & $\begin{array}{c}-4.232^{* * *} \\
(0.655)\end{array}$ & $\begin{array}{c}-5.035^{* * * *} \\
(0.530)\end{array}$ & $\begin{array}{c}-3.686^{* * * *} \\
(0.972)\end{array}$ & $\begin{array}{c}-4.474^{* * * *} \\
(0.756)\end{array}$ & $\begin{array}{c}-3.798^{* * * *} \\
(1.081)\end{array}$ & $\begin{array}{c}-4.677^{* * * *} \\
(0.727)\end{array}$ \\
\hline Loan to Value Ratio & $\begin{array}{l}24.132^{*} \\
(14.347)\end{array}$ & $\begin{array}{c}41.429^{* * *} \\
(6.221)\end{array}$ & $\begin{array}{l}39.720^{* *} \\
(16.452)\end{array}$ & $\begin{array}{c}19.556^{* *} \\
(9.748)\end{array}$ & $\begin{array}{c}6.354 \\
(23.051)\end{array}$ & $\begin{array}{c}31.502^{* * * *} \\
(8.149)\end{array}$ \\
\hline Ln(Herfindahl-Hirschman Index) & $\begin{array}{c}3.698 \\
(2.876)\end{array}$ & $\begin{array}{c}0.709 \\
(1.493)\end{array}$ & $\begin{array}{c}5.847 \\
(3.713)\end{array}$ & $\begin{array}{l}4.166^{* *} \\
(1.983)\end{array}$ & $\begin{array}{l}-1.026 \\
(4.753)\end{array}$ & $\begin{array}{l}-2.641 \\
(2.325)\end{array}$ \\
\hline Number of Stories $>1$ & $\begin{array}{l}-1.244 \\
(1.609)\end{array}$ & $\begin{array}{c}0.388 \\
(1.114)\end{array}$ & $\begin{array}{c}0.218 \\
(2.102)\end{array}$ & $\begin{array}{c}1.662 \\
(1.697)\end{array}$ & $\begin{array}{l}-1.902 \\
(2.420)\end{array}$ & $\begin{array}{l}-0.660 \\
(1.254)\end{array}$ \\
\hline Central Business District & $\begin{array}{c}1.850 \\
(3.140)\end{array}$ & $\begin{array}{c}0.548 \\
(2.234)\end{array}$ & $\begin{array}{l}-2.215 \\
(3.815)\end{array}$ & $\begin{array}{l}-4.087 \\
(3.148)\end{array}$ & $\begin{array}{c}2.778 \\
(4.930)\end{array}$ & $\begin{array}{c}2.472 \\
(3.280)\end{array}$ \\
\hline Renovated & $\begin{array}{c}1.268 \\
(1.187)\end{array}$ & $\begin{array}{c}1.048 \\
(0.968)\end{array}$ & $\begin{array}{c}0.260 \\
(1.558)\end{array}$ & $\begin{array}{l}-0.622 \\
(1.222)\end{array}$ & $\begin{array}{c}1.090 \\
(1.815)\end{array}$ & $\begin{array}{l}-0.035 \\
(1.265)\end{array}$ \\
\hline Hotel & $\begin{array}{c}46.599 * * * \\
(10.469)\end{array}$ & $\begin{array}{c}45.061^{* * *} \\
(5.332)\end{array}$ & $\begin{array}{c}78.155^{* * *} \\
(15.088)\end{array}$ & $\begin{array}{c}44.361^{* * *} \\
(10.010)\end{array}$ & $\begin{array}{c}17.549 \\
(15.021)\end{array}$ & $\begin{array}{c}35.920^{* * * *} \\
(9.609)\end{array}$ \\
\hline Industrial & $\begin{array}{c}16.797^{* * * *} \\
(5.723)\end{array}$ & $\begin{array}{c}18.383^{* * * *} \\
(3.701)\end{array}$ & $\begin{array}{l}25.505^{* *} \\
(10.725)\end{array}$ & $\begin{array}{c}14.973^{* * *} \\
(6.809)\end{array}$ & $\begin{array}{c}-0.003 \\
(10.913)\end{array}$ & $\begin{array}{l}-1.560 \\
(5.260)\end{array}$ \\
\hline Office & $\begin{array}{c}21.598^{* * * *} \\
(5.396)\end{array}$ & $\begin{array}{c}14.015^{* * *} \\
(3.047)\end{array}$ & $\begin{array}{c}25.300^{* * * *} \\
(8.689)\end{array}$ & $\begin{array}{c}11.392^{* *} \\
(4.475)\end{array}$ & $\begin{array}{c}15.644 \\
(11.216)\end{array}$ & $\begin{array}{c}5.439 \\
(5.366)\end{array}$ \\
\hline Other & $\begin{array}{c}24.284^{* * *} \\
(5.864)\end{array}$ & $\begin{array}{c}14.401^{* * *} \\
(3.627)\end{array}$ & $\begin{array}{c}24.489^{* * * *} \\
(8.688)\end{array}$ & $\begin{array}{c}13.897^{* * *} \\
(4.212)\end{array}$ & $\begin{array}{l}18.650^{*} \\
(9.433)\end{array}$ & $\begin{array}{c}11.909^{* *} \\
(6.015)\end{array}$ \\
\hline Retail & $\begin{array}{c}21.146^{* * * *} \\
(4.598)\end{array}$ & $\begin{array}{c}15.866^{* * *} \\
(2.374)\end{array}$ & $\begin{array}{c}32.967^{* * *} \\
(7.975)\end{array}$ & $\begin{array}{c}23.476^{* * * *} \\
(4.940)\end{array}$ & $\begin{array}{c}4.454 \\
(8.757)\end{array}$ & $\begin{array}{l}-0.692 \\
(4.701)\end{array}$ \\
\hline Constant & $\begin{array}{c}513.763^{* * *} \\
(38.132)\end{array}$ & $\begin{array}{c}463.494^{* * *} \\
(26.549)\end{array}$ & $\begin{array}{c}392.925^{* * *} \\
(49.196)\end{array}$ & $\begin{array}{c}437.483^{* * *} \\
(34.248)\end{array}$ & $\begin{array}{c}285.227^{* * *} \\
(65.747)\end{array}$ & $\begin{array}{c}439.638^{* * *} \\
(42.804)\end{array}$ \\
\hline Control Variables & Yes & Yes & Yes & Yes & Yes & Yes \\
\hline Originator FE & Yes & Yes & Yes & Yes & Yes & Yes \\
\hline Borrower FE & Yes & Yes & Yes & Yes & Yes & Yes \\
\hline Year-quarter FE & Yes & Yes & Yes & Yes & Yes & Yes \\
\hline Observations & 16,439 & 25,508 & 7,326 & 10,999 & 9,113 & 14,509 \\
\hline Adjusted $R^{2}$ & 0.879 & 0.821 & 0.915 & 0.854 & 0.902 & 0.847 \\
\hline
\end{tabular}





\section{Appendix A}

\section{Sample and Variables}

Table A1: Distributions of Property Types

Notes: This table reports the number of loans by property types. Sample period: 2000:Q12017:Q3.

Numbers of Loans by Property Types

\begin{tabular}{lrr}
\hline Property Types & Number of Loans by Banks & Number of Loans by Non-Banks \\
\hline Apartment & 4,156 & 8,026 \\
Hotel & 949 & 776 \\
Industrial & 607 & 948 \\
Office & 1,311 & 1,178 \\
Retail & 2,554 & 2,393 \\
Other & 1,881 & 1,524 \\
\hline Total & 11,458 & 14,845 \\
\hline
\end{tabular}


Table A2: Variable Definitions

\begin{tabular}{|c|c|}
\hline Variable & Definition \\
\hline \multicolumn{2}{|l|}{ Geographical Distance } \\
\hline $\operatorname{Ln}\left(1+\right.$ Distance $\left._{\text {Originator-Borrower }}\right)$ & $\begin{array}{l}\text { The natural logarithm of one plus the distance between bank } \\
\text { headquarter and borrower. Distance } \\
\text { from geogrinator-Borrower is calculated } \\
\text { fromic coordinates, in miles. }\end{array}$ \\
\hline $\operatorname{Ln}\left(1+\right.$ Distance $\left._{\text {Branch-Borrower }}\right)$ & $\begin{array}{l}\text { The natural logarithm of one plus the distance between closest } \\
\text { bank branch and borrower. Distance } \text { Branch-Borrower is calculated }_{\text {from geographic coordinates, in miles. }}\end{array}$ \\
\hline $\operatorname{Ln}\left(1+\right.$ Distance $\left._{\text {Originator-Property }}\right)$ & $\begin{array}{l}\text { The natural logarithm of one plus the distance between bank } \\
\text { headquarter and property. Distance } \\
\text { from geogrinator-Property is calculated } \\
\text { fromic coordinates, in miles. }\end{array}$ \\
\hline $\operatorname{Ln}\left(1+\right.$ Distance $\left._{\text {Borrower-Property }}\right)$ & $\begin{array}{l}\text { The natural logarithm of one plus the distance between bor- } \\
\text { rower and property. Distance } \text { Borrower-Property is calculated from }_{\text {geographic coordinates, in miles. }}\end{array}$ \\
\hline
\end{tabular}

Mortgage Loan Characteristics

Debt Service Coverage Ratio The ratio of the income generated by the property to the debt service required by the loan.

Loan to Value Ratio

The ratio of the loan to the value of the property.

$\operatorname{Ln}(1+$ Maturity)

The natural logarithm of maturity, in months.

Ln(Loan Size)

The natural logarithm of loan amount, in millions.

Large Loans

An indicator variable that equals to one for loans in the top tercile of loan size, zero otherwise.

Small Loans

An indicator variable that equals to one for loans in the lower tercile of loan size, zero otherwise.

Spread

The difference between mortgage rates and Treasury bond rates with the same maturities, in basis points.

\section{Property Characteristics}

Age of the Property

Central Business District

Number of Stories $>1$
Indicator variables identifying the age group of the property. Age groups include less than 10, 10-20, 20-30, 30-40, 40-50, and more than 50 .

An indicator variable that equals to one if the property is located in a central business district (CBD), zero otherwise.

An indicator variable that equals to one if the number of stories is greater than one, zero otherwise. 


\begin{tabular}{ll}
\hline Variable & Definition \\
\hline Property Type & $\begin{array}{l}\text { Indicator variables identifying the property type. Property types } \\
\text { include apartment, hotel, industrial, office, retail and other. }\end{array}$ \\
Renovated & $\begin{array}{l}\text { An indicator variable and equals to one for the properties reno- } \\
\text { vated, zero otherwise. }\end{array}$
\end{tabular}

Other Variables

Ln(Herfindahl-Hirschman Index)

Post-crisis

Out-of-State Borrower

Loan Purpose

Metropolitan Statistical Area FE

State FE

Year-quarter FE
The natural logarithm of the summed squares of bank market shares, in each state.

An indicator variable that equals to one for the loans originated after the year 2009, zero otherwise.

An indicator variable that equals to one if the borrower and property are located in different states, zero otherwise.

Indicator variables identifying the loan purpose. Loan purposes include property acquisition and refinance.

Indicator variables identifying the metropolitan statistical area (MSA) where the property is located.

Indicator variables identifying the state where the property is located.

Indicator variables identifying the origination year-quarter of the loan. 



\section{Chapter 3}

\section{The American Inventors Protection}

\section{Act: A Natural Experiment on Innovation Disclosure and the Cost of Debt}

1

\subsection{Introduction}

We assess the effect of patenting activity on reducing innovative firms' cost of debt. Financing innovation by debt is inherently complex. First, innovative firms' assets have lower collateral value, as they are more dependent on intangibles, such as patents and human capital (Hall, 2010). Second, it is difficult to value innovative firms due to cashflow volatility. That is, it is difficult to evaluate whether patent applications will be successful and generate cash flows.

A growing body of academic literature suggests that bank financing is an important source of external capital for innovative firms (Kerr and Nanda, 2015). In the context of bank financing, the risk of innovation failure and the uncertainty of R\&D investment payoffs are potential sources of asymmetric information problems, which are typically associated with reduced access to credit $(\mathrm{Hu}, \mathrm{Li}$, and $\mathrm{Zhu}, 2017)$ as well as higher loan spreads (Francis et al., 2012). Instead of forgoing value-creating R\&D investments, however, innovative firms can use patents to signal the quality of their inventions and thus attempt to alleviate these asymmetric information problems and ease access to credit (Bhattacharya and Ritter, 1983; Francis et al., 2012; Lin, Liu, and Sun, 2017). Yet, there is a trade-off between innovation disclosure through patents and secrecy, as disclosure might

\footnotetext{
${ }^{1}$ This chapter is co-authored with Arvid O.I. Hoffman (University of Adelaide), Stefanie Kleimeier (Maastricht University) and Joost M.E. Pennings (Maastricht University), and published in the International Review of Finance.
} 
enable competitors to obtain valuable technical knowledge (Hall et al., 2014).

We test the impact of innovation disclosure through patents on the cost of debt by exploiting an exogenous change in innovation disclosure: the implementation of the American Inventors Protection Act (AIPA) of 1999. AIPA requires US patent applications filed on and after November 29, 2000 to be published by the government 18 months after the application date. In the pre-AIPA period, patents became public only after they were granted, allowing firms to file as many patents as they wished as a way of trying to avert competition, realizing it would take a long time before the content of their patent applications would be revealed to the market and competitors could learn from it. In contrast, in the post-AIPA period, firms are required to disclose information, even if the patent is not granted eventually. For this reason, firms are expected to have an incentive to apply only for those patents of which they are relatively certain that they will result in a commercial marketplace success; otherwise, the details of their R\&D investments would be revealed to the market, without the firm being able to capitalize on them. Hence, our testable hypothesis is that patents have become a better proxy for successful innovation and therefore have a stronger effect on reducing innovative firms' cost of debt as measured by their loan spreads in the post-AIPA period as compared with the pre-AIPA period. $^{2}$

\subsection{Data and Methodology}

We examine the effect of innovation disclosure on the cost of debt for firms in five innovative industries, which are characterized by high patenting propensities relative to most other industries (Mansfield, 1986), and which have been the focus of prior research (Plumlee et al., 2015). In particular, we examine chemicals and allied products (Standard Industrial Classification (SIC) 28), industrial and commercial machinery and computer equipment (SIC 35), electronics and communications (SIC 36), transportation equipment (SIC 37), and instruments and related products (SIC 38).

We compile our data set as follows. We obtain loans raised by publicly listed US firms from the above-mentioned industries from the Loan Pricing Corporation's DealScan data base. We define our dependent variable, the cost of debt, as the all-in-drawn spread above the London Interbank Offered Rate (LIBOR). We collect patent data for these borrowers from the Worldwide Patent Statistical Database (PATSTAT, version Autumn 2016). We

\footnotetext{
${ }^{2}$ In order to protect small inventors, AIPA includes an opt-out clause under which inventors can preserve pre-grant secrecy beyond 18 months, but forgo foreign protection. If many of our borrowers use this opt-out clause, granted patents will remain a weak signal for successful innovation. Thus, the opt-out clause has the potential to mitigate against our predicted effect. However, Graham and Hegde (2015) report that $<8 \%$ of US patent applications make use of the opt-out, with large US inventors (i.e. our borrowers) opting out less frequently than small US inventors. Therefore, we do not expect that the opt-out clause will substantially affect our results.
} 
consider patents that were eventually granted and end our sample period in 2013 because many later patent applications are still under revision (Hall, Jaffe, and Trajtenberg, 2001). We consider the patent application year as it reflects the actual timing of innovation (Griliches, 1990). We define two proxies: $\operatorname{Ln}(1+$ Patents), reflecting the number of granted patents, and Patent $t_{D}$, a dummy, which is equal to 1 if the borrower has at least one patent application that is eventually granted and zero otherwise. Following prior innovation literature (e.g. Atanassov, 2002), we set the patent count to zero when no patent information is available. We also include loans to firms with no patents to alleviate any possible sample selection concerns. Finally, we include various loan-specific and borrowerspecific control variables from DealScan and Compustat in our empirical model. Patent and borrower variables are observed in the year before loan signing (Francis et al., 2012). The final sample includes 6654 loans raised by 1095 US borrowers between 1985 and 2013. Appendix B summarizes our variable definitions and sources.

The shock to innovation disclosure related to AIPA provides us with a natural experiment in which we can compare the effect of patents on innovative firms' cost of debt before and after the implementation of the law. In particular, we hypothesize that the implementation of AIPA strengthens the negative relation between patents and firms' loan spreads because patents are considered to be a better proxy for successful innovation after the implementation of this law. To differentiate the effect of patents on loan spreads before and after the passage of the law, we divide our sample into a pre-AIPA period that ranges from 1985 to 2000 and a post-AIPA period that ranges from 2001 to 2013. For each subsample, we separately estimate an Ordinary Least Squares (OLS) regression model. We also estimate a difference-in-difference regression model for the full period.

Table 3.1 provides summary statistics and shows that the firms included in our sample are large with an average nominal asset size of $\$ 1.7$ billion in the pre-AIPA period and $\$ 5.0$ billion in the post-AIPA period. The average loan amounts to $\$ 192$ million with a spread of 224 bps above LIBOR pre-AIPA which rises to $\$ 412$ million with a spread of 238 bps above LIBOR post-AIPA. The average firm applies for 11.5 and 5.6 granted patents per year during the pre and post-AIPA period, respectively. The cross-sectional variation is substantial. Pre-AIPA, $66 \%$ of loans are raised by borrowers that did not apply for any patents. Post-AIPA, this fraction rises to $81 \%$. In contrast, the most innovative firm in our sample applies for 856 patents per year in the pre-AIPA period and 791 patents per year in the post-AIPA period. This reduction in granted patents is in line with our expectation that after the implementation of AIPA, firms will apply only for patents of which they are relatively certain that they will result in a commercial marketplace success. 


\subsection{Results}

Table 3.2 presents our results. In regressions (1)-(16), the coefficients of $\operatorname{Ln}(1+$ Patents) and Patent ${ }_{D}$ are of interest and indicate that only in the post-AIPA period, patents have a significantly negative effect on loan spreads. These findings are consistent with the view that, under AIPA, firms have an incentive to only apply for patents if the likelihood of commercial success is large. Otherwise, they would risk revealing confidential information to the marketplace without being able to reap the associated economic benefits. In the post-AIPA period, lenders will thus have more certainty that pending patents will become granted patents, making them (more) predictive for marketplace success and future cash flows. As a result, lenders reward firms with more patenting activity with lower spreads. These results hold for both patent proxies, indicating that the effect is generally present, and not only driven by firms with a large number of patents. Wald $\chi^{2}$ tests in Table 3.3 confirm that the coefficients of our patent proxies are significantly different between the pre-AIPA and post-AIPA period. All control variables have the expected signs. The post-AIPA effects are not only statistically significant but also economically significant. Regression (13) shows that the existence of granted patents reduces spreads by 16.32 bps. For the average borrower, this translates into interest payment savings of $\$ 672,212$ per loan per year. Regression (9) indicates that a one-standard deviation increase in the number of patents reduces the spread for the average borrower by $38.6 \mathrm{bps}$ leading to interest savings of $\$ 1.6$ million per loan per year.

We also identify highly innovative firms as firms whose R\&D expenditures as a percentage of sales are in the highest decile (High R\&D Intensity ${ }_{D}$ ) and expand our regressions by including interaction effects between High R\&D Intensity ${ }_{D}$ and our patent proxies. These interaction effects are significantly negative only pre-AIPA and then only for the $\operatorname{Ln}(1+$ Patents $)$ proxy. Hence, we conclude that pre-AIPA, when patents are only a weak proxy for successful innovation activity, patents can reduce the cost of debt for those firms whose revenues are most sensitive to innovation. However, post-AIPA, as the signaling quality of the patent information improves, this benefit can be captured by all firms. Overall, these results suggest that signaling innovation quality is the underlying mechanism through which patents affect innovative firms' cost of debt.

Inspired by Plumlee et al. (2015), we also examine whether the relationship between innovative firms' cost of debt and patenting activity is stronger for borrowers with a greater initial information uncertainty regarding future cash flows or a greater initial default risk. We identify borrowers with a greater initial information uncertainty as those who are unrated (High Information Uncertainty ${ }_{D}$ ) and extend our regressions by including interaction effects between High Information Uncertainty ${ }_{D}$ and our patent proxies. ${ }^{3}$ We do not find that the effect of patenting activity is different for borrowers with greater

\footnotetext{
${ }^{3}$ Due to the rating fixed effects, there is no need to include High Information Uncertainty ${ }_{D}$ itself in the regressions.
} 
initial information uncertainty. This result is consistent with Plumlee et al. (2015)'s finding that for borrowers with greater initial information uncertainty, only the quality of patenting activity as measured by patent citation count is associated with a lower cost of debt, while the mere presence of patenting activity is not. Next, we identify borrowers with a greater initial default risk (High Default Risk ${ }_{D}$ ) as those with an Altman (1968)'s Z-score at or below the 25th percentile. In our sample, these are borrowers having a Zscore at or below 1.59 pre-AIPA and 2.09 post-AIPA (1.84 in the full period). These values correspond closely to the recommended cutoff level indicating financial distress of 1.81 as identified by Altman (1968) and Altman (2000). We extend our regressions by including interaction effects between High Default Risk $_{D}$ and our patent proxies. ${ }^{4}$ Although the relationship between High Default Risk $_{D}$ and innovative firms' cost of debt has the expected sign, we do not find that the effect of patenting activity on innovative firms' cost of debt depends on their initial default risk.

In regressions (17) and (18), we focus on the full period from 1985 to 2013. Regression (18) can be considered a difference-in-difference model where loans to borrowers with patents constitute the treatment group ( Patent $_{D}=1$ ); loans to borrowers without patents constitute the control group (Patent ${ }_{D}=0$ ); and Post-AIPA Period $\mathrm{P}_{D}$ is the treatment dummy. Considering our hypothesis, the interaction effect Patent ${ }_{D} \times$ Post $-^{-}$ AIPA Period $_{D}$ is of main interest here. The significance of this interaction effect confirms that the signaling quality of the patent information improves after the implementation of AIPA. The negative sign and magnitude of this interaction effect indicate that the existence of granted patents during the post-AIPA period reduces spreads by almost $25 \mathrm{bps}$. The results of regression (17) lead to the same conclusion. ${ }^{5}$

We note that in some regressions, the explanatory power of our models is relatively modest, with adjusted $R^{2}$ values ranging from $28.2 \%$ in the pre-AIPA period to $52.0 \%$ in the post-AIPA period. This observation suggests that besides the variables of interest regarding a firm's patenting activity and the set of controls, other factors also affect innovative firms' cost of debt. Although beyond the scope of the current paper, one such relevant factor could be the quality of a firm's patenting activity as measured by its patent citation count (see, e.g. Plumlee et al., 2015).

\footnotetext{
${ }^{4}$ In contrast to using credit ratings to estimate initial default risk, this approach does not suffer from missing data.

${ }^{5}$ In regressions (1)-(16), we observe substantial differences in the coefficients for High R\&D Intensity ${ }_{D}$ for the pre-AIPA versus post-AIPA period. Hence, we also include an interaction term High R\&D Intensity ${ }_{D}$ $\times$ Post - AIPA Period $_{D}$. Also note that due to the inclusion of year fixed effects, including the Post-AIPA Period $_{D}$ treatment dummy is not strictly necessary, but simply leads to the omission of one additional year fixed effect while the coefficients of our patent proxies and interaction effects are unaffected.
} 


\subsection{Conclusion}

We assess the effect of innovation disclosure through patents on reducing innovative firms' cost of debt using the AIPA as a natural experiment. The implementation of AIPA constitutes a significant change in innovation disclosure regulation, with patent applications becoming public 18 months after filing, whereas previously, patent applications were disclosed only after being granted. We show that innovation disclosure through patenting activity only has a significant effect on the cost of debt in the post-AIPA period. We propose signaling innovation quality via patents as the underlying mechanism that explains the negative relation between patenting activity and the cost of debt. In particular, whereas pre-AIPA, firms had an incentive to apply for a large number of patents as a way of trying to keep out competition, post-AIPA firms have an incentive to apply only for those patents about which they are relatively certain that they will result in a commercial marketplace success.

The publication of patents may thus not only benefit society, in that it facilitates knowledge diffusion (Graham and Hegde, 2015), but also provides firms' private benefits in the corporate loan market in that it allows them to obtain more favorable conditions from banks on their loans. 
Tables 


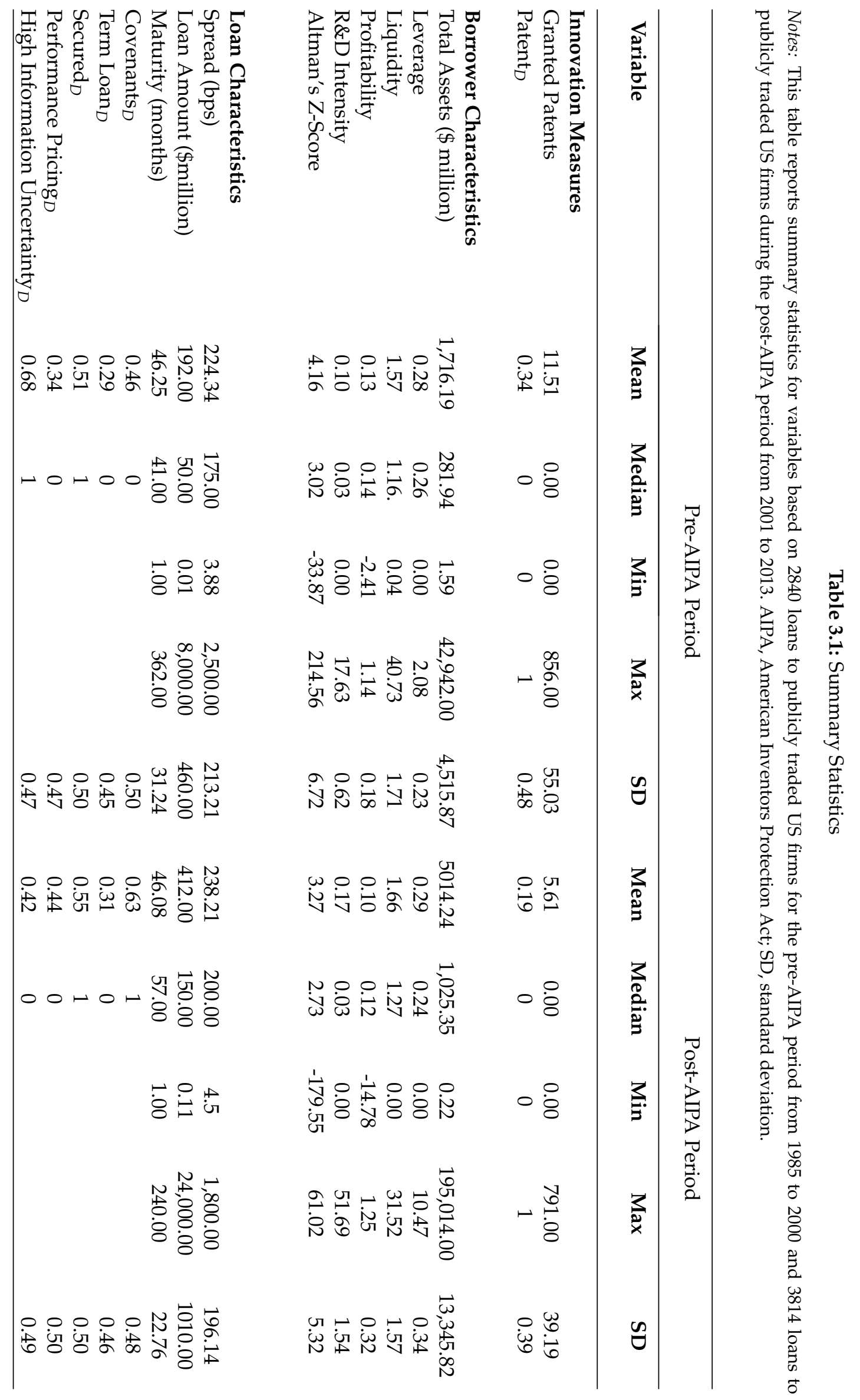




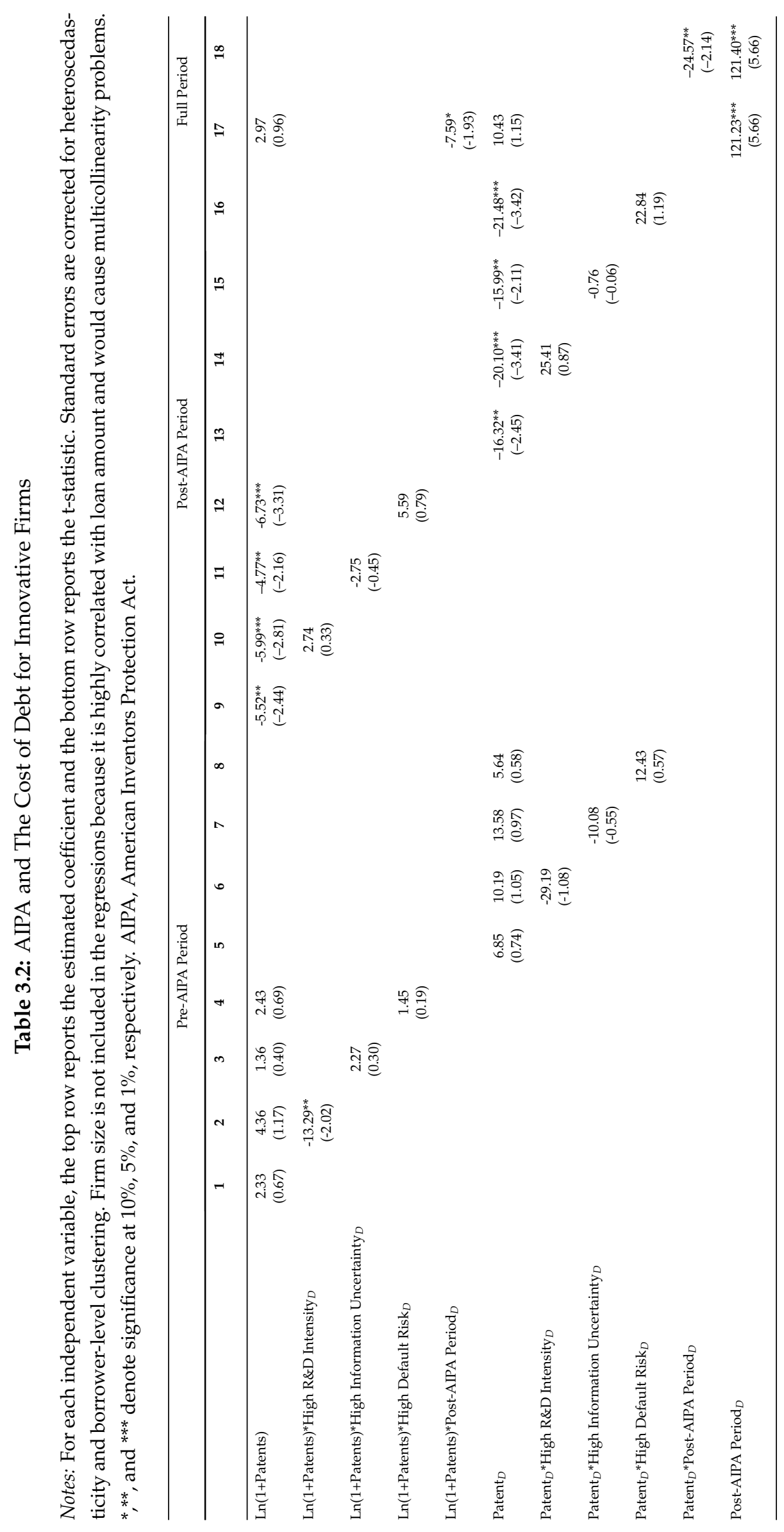




\begin{tabular}{|c|c|c|c|}
\hline 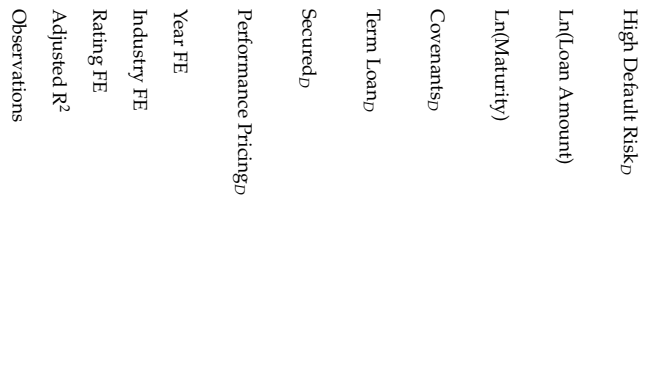 & 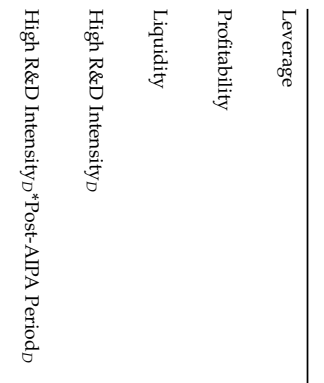 & & \\
\hline 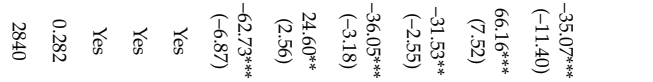 & 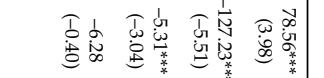 & - & \\
\hline 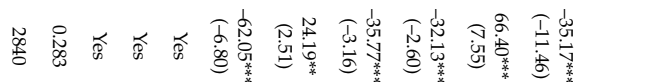 & 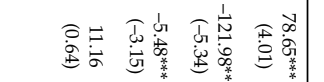 & N & \\
\hline 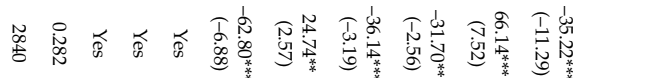 & 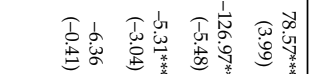 & $\omega$ & \\
\hline 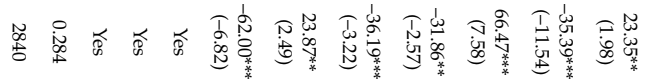 & 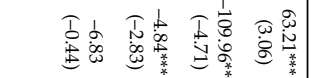 & - & \\
\hline 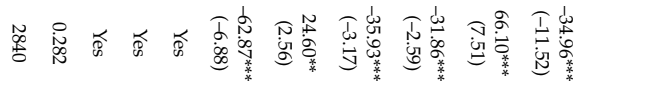 & 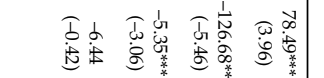 & $\sim$ & 吾 \\
\hline 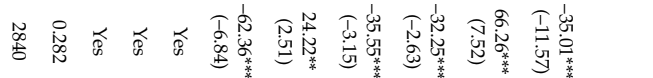 & 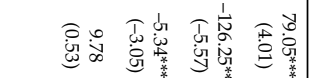 & $\sigma$ & \\
\hline 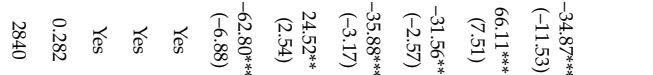 & 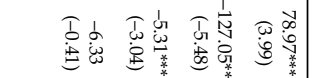 & $\checkmark$ & \\
\hline 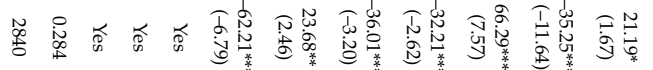 & 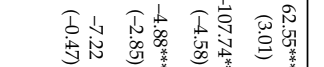 & $\infty$ & \\
\hline 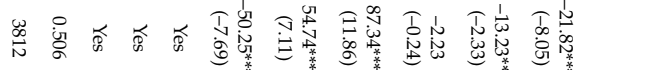 & 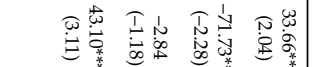 & $\bullet$ & \\
\hline 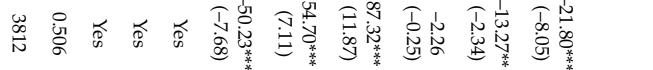 & 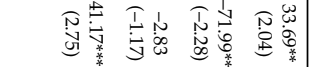 & $\Delta$ & \\
\hline 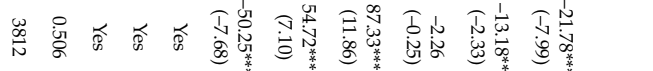 & 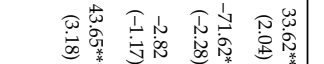 & $=$ & \\
\hline 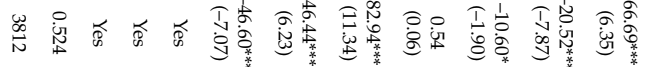 & 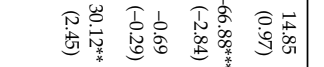 & $\vec{N}$ & 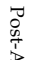 \\
\hline 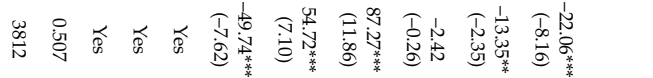 & 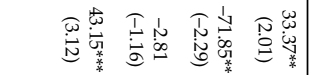 & $\overleftrightarrow{\omega}$ & $\frac{20}{2}$ \\
\hline 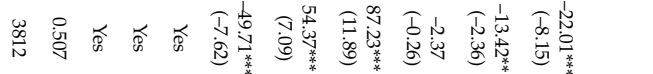 & 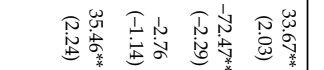 & $\Xi$ & \\
\hline 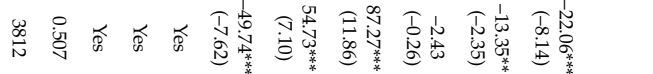 & 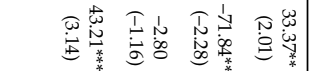 & $\vec{\sim}$ & \\
\hline 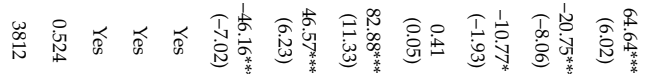 & 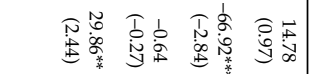 & $\checkmark$ & \\
\hline 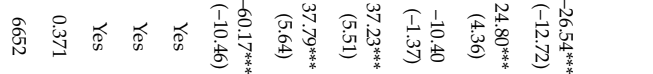 & 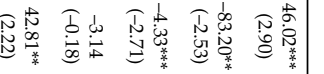 & $\vec{v}$ & TI \\
\hline 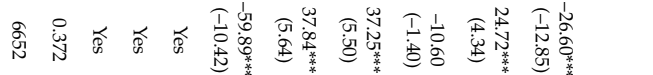 & 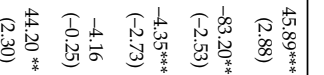 & $\vec{\infty}$ & \\
\hline
\end{tabular}


Table 3.3: Testing for Differences in Coefficients between Pre- and Post-AIPA Periods

Notes: This table reports the results of Wald $\chi^{2}$ tests regarding the coefficient estimates reported in Table 3.2. The test is based on a seemingly unrelated estimation model for the pre-AIPA and post-AIPA periods and tests the null hypothesis of equal coefficients in both periods. ${ }^{*}, * *$, and ${ }^{* *}$ denote significance at $10 \%, 5 \%$, and $1 \%$, respectively. AIPA, American Inventors Protection Act.

\begin{tabular}{lccccc}
\hline \multirow{2}{*}{ Regressions in Table 3.2 } & \multirow{2}{*}{ Variable } & \multicolumn{2}{c}{ Estimated Coefficient } & \multicolumn{2}{c}{ Wald Test } \\
& & Pre-AIPA & Post-AIPA & $\chi^{2}$ & Significance Level \\
\hline (1) and (9) & Ln(1+Patents) & 2.33 & $-5.52^{* *}$ & $3.63^{*}$ & 0.057 \\
(2) and (10) & Ln(1+Patents) & 4.36 & $-5.99^{* * *}$ & $5.86^{* *}$ & 0.016 \\
(3) and (11) & Ln(1+Patents) & 1.36 & $-4.77^{* *}$ & $5.22^{* *}$ & 0.022 \\
$(4)$ and (12) & Ln(1+Patents) & 2.43 & $-6.73^{* * *}$ & $5.18^{* *}$ & 0.023 \\
$(5)$ and (13) & Patent $_{D}$ & 6.85 & $-16.32^{* *}$ & $4.22^{* *}$ & 0.040 \\
$(6)$ and (14) & Patent $_{D}$ & 10.19 & $-20.10^{* * *}$ & $7.41^{* * *}$ & 0.007 \\
(7) and (15) & Patent $_{D}$ & 13.58 & $-15.99^{* *}$ & $3.57^{*}$ & 0.059 \\
(8) and (16) & Patent $_{D}$ & 5.64 & $-21.48^{* * *}$ & $5.69^{* *}$ & 0.017 \\
\hline
\end{tabular}





\section{Appendix B}

\section{Variables}

Table B1: Variable Definitions and Sources

\begin{tabular}{ll}
\hline Variable & Definition \\
\hline Innovation measures (Patstat) & $\begin{array}{l}\text { Dummy }=1 \text { if the borrower has at least one patent application that is } \\
\text { eventually granted, } 0 \text { otherwise. Granted patents are patent applica- } \\
\text { tions that are made in the year before loan signing and that are eventu- } \\
\text { ally granted. }\end{array}$ \\
Latent & Natural logarithm of one plus the number of granted patents.
\end{tabular}

Borrower Characteristics (Compustat)

Firm Size

Leverage

Liquidity

Profitability

R\&D Expenditures

High R\&D Intensity ${ }_{D}$

Altman's Z-Score

High Default Risk ${ }_{D}$

Industry FE
Natural logarithm of total assets (AT) in US\$ million.

Book value of total debt (DLTT+DLC) divided by book value of total assets (AT).

The difference between current assets (ACT) and inventories (INVT) divided by current liabilities (LCT).

Operating income before depreciation (OIBDP) divided by total assets (AT).

R\&D expenditure (XRD) divided by sales (SALE).

Dummy $=1$ if loan is raised by a borrower with an R\&D intensity above the 90 th percentile in pre-AIPA or post-AIPA period, respectively, 0 otherwise.

The score is calculated as $Z=1.2 \times$ working capital/total assets + $1.4 \times$ retained earnings/total assets $+3.3 \times$ earnings before interest and tax/total assets $+0.6 \times$ market value of equity/book value of liabilities $+1.0 \times$ sales $/$ total assets $=1.2 \times W C A P / A T+1.4 \times R E / A T+3.3 \times$ $E B I T / A T+0.6 \times C S H O \times P R C C_{F} / L T+1.0 \times S A L E / A T$.

Dummy $=1$ if loan is raised by a borrower with an Altman's Z-score at or below the 25 percentile in pre-AIPA or post-AIPA period, respectively, 0 otherwise.

Dummies identifying borrower's industry at two-digit SIC level. 


\begin{tabular}{ll}
\hline Variable & Definition \\
\hline Loan Characteristics (Dealscan) & All-in-spread drawn in bps over LIBOR. \\
\hline Spread & Natural logarithm of the loan amount in US\$ million. \\
Ln(Loan Amount) & Natural logarithm of one plus loan maturity in months. \\
Ln(1+Maturity) & Dummy $=1$ if the loan has financial covenants, 0 otherwise. \\
Covenants ${ }_{D}$ & Dummy $=1$ if the loan is a term loan, 0 otherwise. \\
Term Loan ${ }_{D}$ & Dummy $=1$ if the loan is secured, 0 otherwise. \\
Secured & Dummy $=1$ if the loan uses performance pricing, 0 otherwise. \\
Performance Pricing & Dummy $=1$ if the loan is raised by an unrated borrower, 0 otherwise. \\
High Info. Uncertainty & Dummies identifying loan's rating class including a dummy for loans \\
Rating FE & to unrated borrowers. \\
Year FE & Dummies identifying loan's signing year. \\
\hline
\end{tabular}




\section{Chapter 4}

\section{The Effect of Voluntary Non-Financial Disclosure on Green Bond Pricing}

\subsection{Introduction}

Climate change is one of the greatest challenges of our time, and achieving a low carbon economy is a priority for policy makers. The 2015 Paris Agreement under the United Nations Framework Convention on Climate Change (UNFCCC) calls to strengthen the global response to the threat of climate change by keeping a global temperature rise within $2^{\circ}$ Celsius. As climate change undoubtedly alters business environments and economic conditions, new instruments, such as green market securities, have emerged as effective and innovative financial instruments. One of these financial instruments is green bond. Green bonds, also known as climate bonds, are innovative fixed-income debt instruments that finance projects that improve environmental and climate outcomes, such as renewable energy, energy efficiency, clean transportation, sustainable waste management and biodiversity conservation.

Similar to conventional bonds, firms can issue green bonds to finance their investments. A critical question naturally arises: What are the rationales behind green bond issuance? First, issuing green bonds can be a tool for signaling (Flammer, 2018). In particular, issuers can use green bonds to signal to investors and other stakeholders (e.g., consumers, purchasers and NGOs) their commitment to sustainability. Second, it might be a form of "greenwashing" or a marketing tool. For example, some practitioners regard green bond labeling as a marketing tool for the issuer who would fund the project regardless of whether the bond was labeled "green" or not (Bilmes, DuPont, and Levitt, 2015), because the "green" label is related to the use of proceeds of the project rather than the issuer itself. Third, green bonds are possibly issued to create investor clientele.

\footnotetext{
${ }^{1}$ I would like to thank Tom Bour and Wouter Geerlings for their research assistance.
} 
Some investors are willing to forgo financial performance in order to invest in accordance with their preferences (Riedl and Smeets, 2017; Hartzmark and Sussman, 2019). Non-pecuniary motives, specifically pro-environmental preferences, play an important role in holding green assets. A "green label" attracts long-term investors such as mutual funds, pension funds and insurance companies who are seeking for environmentally responsible investing opportunities to allocate funds. Tang and Zhang (2018) suggest that socially responsible funds or investors with a green mandate might hold green bonds in their portfolio to boost their environmental, social and governance (ESG) scores.

Recognizing all of the aforementioned motivations above, I focus on the signaling and investor preferences channels of voluntary disclosure on reducing cost of capital. The impact of voluntary non-financial disclosures has been broadly documented in the accounting literature (Dhaliwal et al., 2011; Plumlee, Brown, and Marshall, 2015; Casey and Grenier, 2015). The basic notion is that firms with high environmental performance benefit from a lower cost of capital. This link is mainly explained through the voluntary non-financial disclosures of corporate social responsibility (CSR) activities. In this chapter, I study the green bond market in order to identify the effect of voluntary disclosure on green bond pricing.

While the green bond market has been expanding rapidly in recent years, there is no international standard to ensure "greenness." Having no standards in the green bond market makes self-labeling a concern for investors. Thus, several third-party verification providers have emerged as a response to investors' demand. Third-party verification as a signaling tool is essential for reducing the information asymmetry and "greenwashing" risk that may entail making misleading claims about the environmental benefits of a firm's practice for the sake of marketing. As it is costly to obtain third-party verification, it is natural to expect that these green bonds may have a lower cost of financing.

Hence, the aim of this chapter is twofold. First, I revisit the research question of whether there are pricing differences between green bonds and conventional bonds in the secondary market. Second, I analyze the impact of voluntary non-financial disclosure, namely third-party verification, on the pricing of green bonds. If third-party verification provides transparency to investors whether the bond actually have climate-related benefits, it reduces information asymmetry, which in turn lowers the issuer's cost of financing.

In order to analyze the yield spread between a green bond and a conventional bond, I start with non-parametric tests and finish with regression analyses. Although the matching method captures part of the liquidity effects by matching based on maturities and issue amount as proxies for liquidity (Houweling, Mentink, and Vorst, 2005; Bao, Pan, and J., 2011), it does not capture all liquidity effects. Thus, in addition to non-parametric tests, I also perform regression analysis and control for residual liquidity. Specifically, I 
follow the fixed-effects panel regression approach of Zerbib (2019). To address my first research question, I compare the yield of a green bond with a counterpart conventional bond, matched on the basis of issuer, issue date, size, maturity, currency, rating, seniority and coupon type. Green and conventional bonds of the same issuer are subject to the same credit risk once I control for all their differences (Zerbib, 2019). Hence, I can isolate the "greenness" effect on the pricing. Building on the methodologies of Helwege, Huang, and Wang (2014) and Zerbib (2019), I perform a fixed-effects panel regression of the yield differential on the bonds' liquidity differential on matched pairs, and the green bond premium is defined as the unobserved specific effect of this regression. The results show that, on average, there is no significant premium for green bonds, and the yield of a green bond is economically identical to that of a conventional bond.

In the second part of the analysis, I explain the yield differential between a green bond and paired conventional bond according to the third-party verification of the bonds through a cross-sectional regression. In order to do so, I hand-collect the third-party verifications from issuers' and Climate Bond Initative's (CBI) websites, and create a disclosure score based on the Green Bond Principles' classification: second party opinion, verification, rating and certification. I find that the third-party verification reduces asymmetric information between investors and issuers, and enhances investor confidence as such disclosure is viewed as credible. Specifically, a third-party verification can significantly reduce the yield spread by 44 bps.

This chapter contributes to the literature on impact of voluntary non-financial disclosure practices on capital markets. Specifically, the findings of this study contribute to the nascent literature on green bonds by investigating the effect of external review on the green bond pricing for a hand-collected sample of third-party verifications for 111 green bonds. To the best of my knowledge, there is no study investigating the thirdparty verification effect as thoroughly as I do in this paper. This study fills this gap in the literature and give insights about the external review effect on the pricing of green bonds.

The results of this study have a number of policy implications. It is particularly important for policymakers and standard setters to be aware of the extent to which standards could further improve the credibility of green bonds. For example, the European Commission focuses on creating standards and labels for green financial products to establish a common taxonomy (European Commission, 2018). As there is an urgent need for making the transition towards a low-carbon economy, green bonds are promising financial instruments to meet investment needs for environmentally friendly solutions. However, lack of standards leads to the risk of greenwashing and acts a barrier to the development of a well-functioning green bond market. Cochu et al. (2016) note that the "lack of green bonds definition and framework" is one of the key bottlenecks that hamper the growth of the green bond market. The findings of this chapter show that third-party 
verification can boost investor confidence and protects against greenwashing by reducing information asymmetries between issuers and investors. Thus, a well-defined greenness measure either in the form of some accepted standards or independent reviewers is an important concept for further development of this market.

The remainder of this chapter is organized as follows. Section 4.2 presents the literature review. Section 4.3 describes the development of the green bond market, and presents the theoretical framework and hypotheses. Section 4.4 describes the data construction and methodology. Section 4.5 presents the results. Section 4.6 concludes.

\subsection{Literature Review}

Financial and environmental risks interact with each other. It has been documented that better environmental risk management is related to a lower cost of capital (Sharfman and Fernando, 2008; Chava, 2014). Richardson and Welker (2001) suggest two alternative mechanisms for how CSR disclosures can affect a firm's cost of capital: investor preferences for socially responsible investing or reduced information asymmetry and/or estimation risk. They argue that social disclosure could affect the cost of capital through investor preferences if investors are willing to accept a lower rate of return on investments. In the latter case, it affects the cost of capital by reducing the uncertainty regarding the distributions of returns.

A stream of accounting literature has focused on the link between voluntary nonfinancial disclosure and the firm's cost of capital. These studies suggest a signaling role for voluntary non-financial disclosures, and generally use information on CSR performance in annual or standalone CSR reports and 10-K filings. In the last decades, with the steadily increasing emphasis on socially responsible activities, more firms have become willing to voluntarily issue CSR reports. For example, Dhaliwal et al. (2011) investigate whether the initiation of voluntary disclosure of CSR activities by using a standalone CSR report is associated with a firm's cost of equity capital. The authors show that the cost of equity capital decreases for firms that initiate standalone disclosure of CSR activities. In contrast, Clarkson et al. (2013) do not find any significant association between voluntary environmental disclosures and cost of equity capital. By using a self-constructed disclosure index as a measure of disclosure quality, Plumlee, Brown, and Marshall (2015) find both positive and negative associations between disclosure quality and cost of equity.

Another stream of literature looks into the relationship between CSR assurance and the cost of capital. As skepticism about the CSR reports has recently increased among the investors and stakeholders, assurance plays an important role in enhancing credibility and reliability of CSR reporting (Adams and Evans, 2004; Casey and Grenier, 2015). For example, Casey and Grenier (2015) show that CSR assurance is associated with reduced 
cost of capital and this effect is more pronounced when an accounting firm provides CSR assurance. Similarly, Martínez-Ferrero and García-Sánchez (2017) examine whether the decrease in cost of capital as a result of voluntary disclosure is greater when sustainability reports are assured by an external third party. They find that voluntarily disclosing CSR information reduces a firm's cost of capital by decreasing investors' uncertainty and information asymmetry between firm and capital markets. Furthermore, this reduction is more significant if firms prefer demanding an assurance statement.

Although the vast majority of empirical studies has focused on the relationship between corporate social responsibility (CSR) and cost of equity (see Dhaliwal et al., 2011; El Ghoul et al., 2011; Plumlee, Brown, and Marshall, 2015), there are relatively few studies investigating the relationship between CSR and cost of debt. Menz (2010), focusing on the European corporate bond market, shows that the risk premium for socially responsible firms does not significantly differ from that of less responsible corporations, and concludes that CSR has not yet been incorporated into the pricing of corporate bonds. Oikonomou, Brooks, and Pavelin (2014) investigate the effect of corporate social performance on corporate bond spread. They find that good corporate social performance is associated with lower bond yields. Ge and Liu (2015) show that a higher overall CSR performance score is associated with lower bond spreads. Conversely, in line with the shareholder theory, Magnanelli and Izzo (2017) show that corporate social performance increases the cost of debt.

The green bond market is young, thus there is not much recent work investigating the pricing of green bonds and determinants of green bond pricing. Flammer (2018) investigates whether green bonds deliver on their promise, or are rather a form of "greenwashing." After analyzing 368 corporate green bonds, she concludes that corporate green bonds are effective - they yield improvements in companies' environmental footprint, and contribute to financial performance. Most of the studies on green bonds are devoted to measuring the magnitude of yield differences between green bonds and conventional bonds (Tolliver, Keeley, and Managi, 2020). For example, Ehlers and Packer (2017) study a smaller sample of 21 green bonds to analyze the price effect of having a green label in the primary market, and they find a negative premium of $-18 \mathrm{bps}$. Hachenberg and Schiereck (2018) analyze a sample of 63 green bonds in the secondary market and find a negative premium of $-1 \mathrm{bp}$. Conversely, Tang and Zhang (2018) do not find a significant premium for green bonds. Karpf and Mandel (2018) study municipal bonds in the secondary market and show a positive premium of $7.8 \mathrm{bps}$. By focusing on U.S. municipal and corporate green bonds, Baker et al. (2018) suggest that green bonds are issued at a premium to otherwise similar ordinary bonds in the primary market. They suggest that some investors are willing to sacrifice some return to hold green bonds. Their results also indicate that green bonds have more concentrated ownership. Moreover, those effects are stronger for 
externally certified bonds. By analyzing 640 matched pairs of municipal green and nongreen bonds, Larcker and Watts (2020), however, observe economically identical pricing for green and non-green issues. They also investigate the effect of certification on the pricing of municipal bonds, and find a very small economic effect. They suggest that CBI Climate Certification is welfare decreasing for municipalities since third-party certification is costly. Using a matching procedure, Zerbib (2019) demonstrates that the yield of a green bond is lower than that of a conventional bond in a sample of 110 bond pairs, and the main determinants of the premium are rating and issuer type: The negative premium is more pronounced for financial and low-rated bonds. Fatica, Panzica, and Rancan (2019) find a premium for green bonds issued by supranational institutions and corporates while they conclude there is no effect for financial institutions. Gianfrate and Peri (2019) study European green bonds using a propensity score matching approach, and they find a negative premium of -18 bps. In sum, existing studies provide mixed results on green bond pricing.

This chapter attempts to move the literature forward by filling a gap left by previous studies on green bonds. It goes beyond investigating the pricing differences between a green bond and a conventional bond by searching for the effect of voluntary non-financial disclosure on green bond pricing. Thus, this chapter enhances our understanding of the consequences of voluntary non-financial disclosure in the green bond market.

In the next section, I present the hypotheses based on the theoretical motivations after reviewing the development of the green bond market and disclosure practices.

\subsection{Background and Hypotheses Development}

\subsubsection{The Development of the Green Bond Market}

The green bond market has grown significantly in recent years but still is a niche market. Until 2013, green bond issuers were predominantly supranational entities such as the Asian Development Bank (ADB), the African Development Bank (AfDB) and the European Bank for Reconstruction and Development (EBRD). The first green bond, labeled a Climate Awareness Bond (CAB), was issued in 2007 by the European Investment Bank (EIB). The following year, the World Bank launched its first green bond in response to specific demand from Scandinavian pension funds seeking to support climate-focused projects. ${ }^{2}$ In 2013, the International Finance Corporation (IFC) issued a USD 1 billion green bond, the largest green bond in the market at the time.

In 2013, the French utility company EDF, the leading Swedish real estate company Vasakronan, and the Bank of America issued the world's first green corporate bonds. The

\footnotetext{
${ }^{2}$ World Bank, What are Green Bonds?
} 
market evolved, and municipalities and governments started to join the market. The first green bonds were issued by Ile-de-France in 2012, followed by Gothenburg (Sweden), Massachusetts (USA), California (USA), and the Province of Ontario (Canada). Since then, the market has continued to grow rapidly, reaching a total of USD 37 billion in 2014, and USD 40 billion in 2015. In December 2016, Poland was the first country to issue a sovereign green bond. In 2017, green bond issuance had a volume of USD 156 billion. ${ }^{3}$ For the first half-year of 2019, issuance of labeled green bonds reached USD 126 billion. For this period, corporate issuers constituted about $37 \%$ of new green bond issuance, followed by financial institutions (21\%), and sovereigns (14\%). ${ }^{4}$

\subsubsection{Reporting and Disclosure}

From the issuer's perspective, green bonds provide several benefits, such as investor base diversification and signaling to stakeholders on environmental responsibility. By issuing green bonds, issuers can highlight environmentally friendly attributes and hence potentially attract investors with an environmental, social, governance (ESG) and socially responsible investment (SRI) mandate (Ng and Tao, 2016). However, the notion of what is "green" remains a concern for investors, since there is no a set of universally agreed-upon green bond standards yet. Thus, voluntary disclosure can be fundamental for issuers to signal whether they kept their promises and to declare how they spent the funds.

There are currently two initiatives that verify the integrity of the "green bond" label: the Green Bond Principles (GBPs) and the Climate Bond Initiative (CBI). The GBPs are socalled "voluntary process guidelines" that encourage transparency and disclosure, and were introduced by the International Capital Market Association (ICMA) in January 2014 and updated yearly thereafter. These principles are organized around four elements: (i) the use of proceeds of the bond issue; (ii) the process for evaluating and selecting projects; (iii) the management of the proceeds; and, (iv) reporting and disclosure regarding the proceeds and the project financed (ICMA, June 2018).

The GBPs recommend public disclosure of external reviews. The external reviewers' main role is to provide independent opinion by confirming alignment of the green bond with specific green bond framework or standards. Green bonds that are verified by qualified third parties likely represent a more credible commitment (Flammer, 2018), because independent third-party organizations safeguard the market from the risk of greenwashing (Park, 2018). According to the Green Bond Principles, Voluntary Process Guidelines for Issuing Green Bonds (ICMA, June 2018), external reviews are broadly grouped into the following types: second party opinion, verification, rating and certification.

\footnotetext{
${ }^{3}$ Green Bond Highlights 2017, Climate Bonds Initiative.

${ }^{4}$ Environmental Finance Sustainable Bonds Insight-H1 2019 Market update.
} 
Second-Party Opinion: An institution with recognized environmental expertise provides a second-party opinion on an issuer's green bond framework and guidance for assessing and selecting eligible projects for green bond investments (ICMA, June 2018). This type of external review is the predominant form of external assurance in the green bond market. The most common second-party opinion providers include CICERO - Center for International Climate Research, Vigeo Eiris, Oekom Research, DNV GL and Sustainalytics (Flammer, 2018).

Verification: In contrast to certification, verification may focus on alignment with internal or external standards or claims by the issuer (ICMA, June 2018). An issuer can obtain independent verification supplied by qualified parties, such as auditors. Assurance regarding an issuer's internal tracking method for the use of proceeds and alignment of reporting with the GBP standards may also be termed verification (ICMA, June 2018). The most active assurance providers are KPMG, PwC, Deloitte and EY.

Green Bond Scoring/Rating: An issuer can have its green bond, green bond framework or use of proceeds evaluated by qualified third parties according to an established scoring/rating methodology (ICMA, June 2018). Green bond ratings are separate from an issuer's ESG rating as they apply to individual securities or green bond frameworks.

Certification: An issuer can obtain certification against a recognized external green standard or label for its green bond, green bond framework or use of proceeds (ICMA, June 2018). With the certification, the issuer is entitled to use a certification logo for a specific green bond issuance.

The CBI also provides a certification procedure (Ehlers and Packer, 2017). The CBI's Climate Bonds Standard establishes sector specific eligibility criteria for certification, and it allows for certification of a bond prior to its issuance. An approved verifier supplies an assurance report to confirm that the bond meets the Climate Bonds Standard's requirements. After the issuance and allocation of the bond proceeds, the issuer must confirm the certification by obtaining another assurance report and providing that to the Climate Bonds Standard Board. ${ }^{5}$

\subsubsection{Theoretical Motivation and Hypotheses Development}

Investors can be driven by financial motives, non-pecuniary motives, or both. For example, Kinder (2005) defines "value-based" and "value-seeking" investing: Values-based investing "sought to align — to the extent possible — an investor's portfolio holdings with his/her/its beliefs," whereas value-seeking investing "seeks to identify social and environmental criteria which may affect financial performance" (p. 11). Similarly, Nilsson (2009) defines three different segments of investors for socially responsible investing

\footnotetext{
${ }^{5}$ Climate Bonds.
} 
(SRI) mutual funds: investors who primarily care about financial returns, those whose primary concern is non-pecuniary motives and those who value both financial and nonpecuniary returns.

In the green bond market, the huge demand is coming from mainstream institutional investors who are seeking to align their investments with the low-carbon agenda. ${ }^{6}$ Those investors might be willing to make a trade-off between yield and a green label: If some "value-based" investors care about the non-pecuniary aspects of their investment, they may forgo financial returns and be willing to accept a lower yield. As a consequence, the yield difference between the green bond and its conventional counterpart should be negative. This leads to my first hypothesis.

Hypothesis 1. Green bonds have a lower yield than their conventional counterparts.

I also consider whether "greenness" affects the yield difference between a green bond and a conventional bond. Since there is no universally accepted definition of "green" yet, disclosure, transparency and reporting are presumably fundamental in the green bond market. Furthermore, investors know little about the real environmental impact of green bonds, so they can only obtain information through voluntary disclosures (Tang and Zhang, 2018).

Signaling theory provides an economic rationale for companies to engage in voluntary disclosure practices (Verrecchia, 1983; Dye, 1985). Voluntary disclosure is one of the signaling means, where companies would disclose information in order to signal that they are better than some others (Campbell, Shrives, and Saager, 2001). In the green bond market, issuers disclose certain information to investors for the purpose of reducing information asymmetry and to indicate that they are more comitted to sustainability than some other issuers. For instance, instead of self-labeling, issuers can choose to have independent third-party verifications concerning the greenness of a bond. Thus, bonds without third-party verifications might have a higher risk of greenwashing. Thirdparty verifications highlight to investors that the proceeds are funding environmentally responsible projects, thus improve issuers' reputational image and broaden its access to capital. However, signaling, namely third-party verification, is costly; issuers will be subject to additional transaction costs such as a sustainability consultant, holding proceeds in a separate account, monitoring and reporting the use of proceeds (Hachenberg and Schiereck, 2018). For instance, the CBI asks a flat fee equal to 0.1 basis points of the issue value in order to certificate the green label. Issuers may also bear the cost of providing regular reports after the issuance.

\footnotetext{
${ }^{6}$ Climate Bonds.
} 
Another way of disclosure is regular reporting of the use of proceeds of specific projects. Green bond issuers publish post-issuance reports which detail how proceeds are allocated, and the environmental outcomes of the projects such as the resulting reduction in the volume of carbon dioxide emissions. Even though many post-issuance reports do not clearly identify the additionality of green bond impacts (Tolliver, Keeley, and Managi, 2019), they could still aid investors to identify green investment opportunities. Furthermore, voluntarily disclosing the use of proceeds demonstrates issuers' confidence in their performance, which sends a positive signal to investors. Thus, the yield differential between a green bond and a conventional bond might vary with the independent third-party verification due to the reduced information asymmetry. This argument is also in line with the economic theory which suggests that a firm's commitment to greater disclosure should lower the information asymmetry component of the firm's cost of capital (Leuz and Verrecchia, 2000). Therefore, I state my second hypothesis as follows.

Hypothesis 2. Third-party verification is negatively associated with the yield spread between a green bond and a conventional bond.

In the next section, I explain the data and methodology to test my hypotheses.

\subsection{Data and Matching Method}

To address my main research question of whether there is a green bond premium or not, I compare the yield differential between a green bond and an otherwise identical conventional bond. In the absence of counterfactual information, the best methodological approach is a matching method, which consists of matching a pair of securities with the same relevant observable characteristics except for the one whose effects we are interested in. The matched-pair approach has been widely used to compare the returns of ethical funds and conventional funds (Statman, 2000; Kreander et al., 2005; Bauer, Koedijk, and Otten, 2005; Renneboog, Ter Horst, and Zhang, 2008), and for analyzing the impact of liquidity on corporate bond spreads (Dick-Nielsen, Feldhutter, and Lando, 2012; Helwege, Huang, and Wang, 2014).

My empirical approach is close to Helwege, Huang, and Wang (2014): I identify pairs of bonds with identical credit risk features. To construct my sample, I start with extracting all bonds complying with the Green Bond Principles and were issued from January 2007 to December 2017. For each green bond in the data set, I search for a conventional bond that is as similar as possible based on specific bond characteristics: the same issuer, coupon type, rating, and currency (Helwege, Huang, and Wang, 2014; Bachelet, Becchetti, and Manfredonia, 2019). By doing so, I remove unobservable credit risk factors. Thus, the yields of these bonds do not differ because of heterogeneous credit risk 
or taxes. It follows that the yield differential between a green bond and a counterfactual conventional bond will be the cumulative effect of the liquidity differential and the green bond premium (Zerbib, 2019). Liquidity is not readily measured (Helwege, Huang, and Wang, 2014), but it can be assessed from either issue amount or issue date (Houweling, Mentink, and Vorst, 2005; Bao, Pan, and J., 2011; Zerbib, 2019). Thus, I consider conventional bonds with an issue amount to four times larger or smaller (Bachelet, Becchetti, and Manfredonia, 2019), and allow for a difference of, at most, six-year interval for the issue date (Zerbib, 2019).

Moreover, I only include fixed-coupon bonds as floating bonds have a non-constant coupon that is linked to particular reference rate, e.g., the LIBOR (Helwege, Huang, and Wang, 2014; Gianfrate and Peri, 2019; Zerbib, 2019). Preferably, the pair would also have the same coupon-rate, but this restriction reduces the number of observations. Thus, I require that the difference in the coupon-rates of the matched bonds be no more than $0.75 \%$. In order to identify each bond's credit rating, I check their S\&P or Moody's credit ratings. Alternatively, I use the rating of the issuer on senior unsecured debt as a proxy for the bond's rating if those ratings are not available. Except for one BB and three non-rated ones, all bonds in my sample are investment-grade bonds. The vast majority of bonds are AAA rated $(40.54 \%)$. Since it is almost impossible to find two bonds with exactly the same maturity, I allow for a difference of two years between the maturity dates in the pairs. In the matching process, I use a bond only once (Helwege, Huang, and Wang, 2014). Based on these considerations I identify 111 bond pairs.

As a last step, I build a panel composed of pairs of bonds. I collect daily observations of ask and bid price, and ask yield from the issue date of the bond up to July 31, 2019. I focus on the ask yield, as I am interested in the investor demand (Zerbib, 2019). Lastly, I require non-missing values for all covariates. The final sample includes 42,843 unbalanced bond-day observations for 60 issuers. According to the first level of the Bloomberg Industry Classification System (BICS1), which classifies the industry sector of the issuer, the majority of issuers are government-related institutions, and account for $50.77 \%$ of the number of issuances. The second major group of issuers are represented by entities in the financial industry, which account for $40.00 \%$. The remaining corporate issuers are belong to different industry sectors, namely "Consumer Discretionary," "Industrials," "Technology" and "Utilities."

In the following, I provide some stylized facts based on the sample. Figure 4.1 and Figure 4.2 depict the breakdown by country and currency, respectively. The majority of the issuers are from Sweden (17.12\%), Germany (14.41\%) and USA (9.01\%), and the majority of the currencies are USD (43.24\%), EUR (27.03\%) and SEK (15.32\%).

Table 4.1 presents the summary statistics of the green and conventional bonds in the 
sample. The number of days per bond indicates the length of the time series in the sample per bond, and it is on average, 386 days. The average green bond yield is slightly higher than the average conventional bond yield (1.73 versus 1.69 ). The average yield spread is 4 bps. The distribution of coupons is very similar in the two groups. The average maturity is 6 years for both group. The average issue amount is higher for conventional bonds (USD 1,034 million versus USD 625 million).

\subsection{Results}

\subsubsection{Is There a Green Bond Premium?}

I begin my analysis by comparing the ask yield of a green bond and a counterpart conventional bond for the days when both bonds were traded. Table 4.2 presents the mean and median pricing differentials between the matched pairs of green and conventional bonds along with a paired two-sided $t$-test and a Wilcoxon matched-pairs signed-ranks test. The paired two-sided t-test and the Wilcoxon test show that the differences between mean and median yields are statistically significant and equal to 3.8 and 3 basis points, respectively. This positive differential implies a green bond discount rather than a green bond premium.

Although the matching method captures part of the liquidity effects by matching based on maturity and issue amount which are established proxies for liquidity (Houweling, Mentink, and Vorst, 2005; Bao, Pan, and J., 2011), it likely does not capture all liquidity effects. Moreover, the conventional bond market is much larger and more liquid than the green bond market. Thus, in addition to these non-parametric tests, I also perform regression analysis. Specifically, following Zerbib (2019), I estimate a fixed-effects panel regression and control for residual liquidity in the regression analysis. For this purpose, I define the liquidity of a bond as the bid-ask spread as it has been widely used in the literature as a proxy for the degree of illiquidity of a bond (Chen, Lesmond, and Wei, 2007, Dick-Nielsen, Feldhutter, and Lando, 2012). $\Delta$ Liquidity $_{i, t}$ is therefore calculated as the difference between a green bond and a conventional bond's liquidity indicator (Zerbib, 2019) as stated in Equation (4.1).

$$
\Delta \text { Liquidity }_{i, t}=\text { Liquidity }_{i, t}^{G B}-\text { Liquidity }_{i, t}^{C B}
$$

The fixed-effects panel regression on matched pairs of bonds, as opposed to the crosssectional regression of yields on bonds' characteristics, solves the problem of a bias related to overweighting bonds with the longest price history (Zerbib, 2019). Specifically, I estimate fixed-effects panel regression of the following form, clustering standard errors on the issuer level:

$$
\Delta y_{i, t}=p_{i}+\alpha_{0} \Delta \text { Liquidity }_{i, t}+\epsilon_{i, t}
$$


where $\Delta y_{i, t}$ is the difference between the green bond ask yield and the conventional bond ask yield for the $i$ th bond pair on day $t$. The green bond premium $p_{i}$ is the bond specific time-invariant effect in the fixed-effects panel regression. Hence, $p_{i}$ is a part of the yield spread that cannot be explained by any liquidity differential. In other words, the yield spread is the cumulative effect of the liquidity differential and the green bond premium (Zerbib, 2019). As the bond characteristics such as the issue amount and maturity do not change over time for a given bond and are therefore absorbed by the fixed effects, I don't control for them.

Table 4.3 reports the regression results for Equation (4.2). ${ }^{7}$ The results indicate that liquidity (coefficient estimate of 0.331 , significant at the $1 \%$ level) impact the yield spread. I obtain the 111 fixed effects, $\hat{p}_{i}$, each of the green bonds' premium from the Equation (4.2). Table 4.4 shows that the distribution ranges from -99 basis points to 62 basis points with a mean value of 0 . Thus, on average, I do not find a significant green bond premium, and the yield of a green bond is economically identical to that of a conventional bond.

\subsubsection{The Effect of Voluntary Disclosure}

In this section, I investigate how the estimated yield spread varies with third-party verification. If bonds with non-financial disclosure are valued more by investors, I would expect to find a negative relationship between voluntary non-financial disclosure and yield spread.

Bloomberg defines bonds as a green bond when an issuer self-labels its bond as "green" or accompanies its bond issuance with additional statements. ${ }^{8}$ Thus, not all issuers have had an independent review for their bonds in my sample. In order to test my hypothesis that the third-party verification would give more confidence to investors and therefore reduces the yield spread, I hand collect all the external review reports and the relevant information from the issuers' and Climate Bond Initative's (CBI) websites. In line with the Voluntary Process Guidelines for Issuing Green Bonds of GBP (ICMA, June 2018), I classify the disclosure information into four categories: (1) second party opinion, (2) verification, (3) rating and (4) certification. Reporting is not uniform across the green bond universe. In the pre-issuance phase, an independent third-party certifies that the projects to be financed by the green bond proceeds are eligible under the specific certification standards or guidelines, and the issuer has established internal frameworks and controls to keep track of how the bond proceeds are used (Flammer, 2018). In the postissuance phase, the independent third party verifies that the bond proceeds have been allocated to green projects in accordance with the standards (Flammer, 2018). I include all the pre-issuance reviews as second-party opinions, and all the post-issuance reviews

\footnotetext{
${ }^{7}$ I also perform a Hausman test for a random-effects model versus a fixed-effects model. The results of the Hausman test suggest that the random-effects estimator will produce biased estimates $(p=0.0013)$. Thus, the preferred estimator is the fixed-effects within estimator.

${ }^{8}$ BNEF Bloomberg Terminal Guide, 10 September 2015.
} 
as verification. Based on these considerations, out of 111 bonds, I identify 75 bonds that have obtained a second-party opinion, 71 bonds that have a verification, 23 bonds that have a bond rating and 12 bonds that are certified. In my sample, the most active second-party opinion provider and assurer are CICERO (for 42 bonds) and EY (for 18 bonds), respectively.

I estimate a cross-sectional specification through an ordinary least squares (OLS) regression as stated in Equation (4.3) to test whether verification has an impact on the yield differential between a green bond and a conventional bond. In the regression, $\hat{p}_{i}$ refers to the estimated yield spread of bond pair $i$. The variable of interest is Verification ${ }_{j}$, and is equal to one if the issuer obtains a post-issuance review for a specific bond $j$, and zero otherwise. I control for a set of bond characteristics that may affect the yield spread. Specifically, I control for rating, maturity, amount, currency, industry and country of the issuer. Based on the previous literature (e.g., Friewald, Jankowitsch, and Subrahmanyam, 2012), I group the ratings into categories as shown in Table $\mathrm{C} 2$ (i.e., $\mathrm{AAA} / \mathrm{Aaa}=1, \mathrm{AA}+/ \mathrm{Aa} 1=2$, etc.). Generally, bonds with longer maturities are riskier than bonds with shorter maturities (Khurana and Raman, 2003). I therefore control for the bond maturity. I also correct the standard errors by clustering at the issuer level.

$$
\widehat{p}_{i}=\alpha_{0}+\alpha_{1} \text { Verification }_{j}+\Sigma \alpha_{2} \text { Bond Characteristics }_{j}+\epsilon
$$

Table 4.5 shows the main results for this test. Column (1) only includes traditional bond pricing determinants. In column (2), the coefficient estimate for Verification is not statistically significant for the full sample. Hence, I do not find any statistically significant relationship between third-party verification and the estimated yield spread.

Simnett, Vanstraelen, and Chua (2009) found that the demand for CSR assurance was strongest in finance and utilities industries. They argue that these industries are more exposed to social and environmental risks and, thus, possess a greater need to increase user confidence in the credibility of their reported activities. Similarly, Fatica, Panzica, and Rancan (2019) suggest that for financial institutions, it might be more difficult to mitigate information asymmetry and to signal their environmental commitment to the capital markets. Therefore, I run the regression for the subsample of issuers classified as "Financials" and present the result in column (4) of Table 4.5. The coefficient for Verification remains insignificant for financial issuers, too. As a post-issuance external review, verification itself does not have any significant impact on the yield spread. In order to deepen my analysis, I construct a disclosure score based on four categories of external review in the next section. 


\section{The Disclosure Score}

A disclosure score is constructed to measure the extent of disclosure provided on issuers' and Climate Bond Initative's (CBI) websites. I manually categorize all available information concerning green bond non-financial disclosure for each of the 111 bonds. In line with the Green Bond Principles, the disclosure score contains four disclosure categories: (1) second-party opinion, (2) verification, (3) certification and (4) rating (ICMA, June 2018).

Following the disclosure literature, all disclosed information is regarded to be equally valuable (Chau and Gray, 2010). I develop a disclosure score based on a binary system: disclosure of one category adds one point, and insufficient disclosed information adds zero point. Based on these considerations, I identify 8 bonds that have none of the external review categories, 42 bonds that have one of the external review categories, 48 bonds that have the two types of external review categories, 10 bonds that have the three types of external review categories, and 3 bonds that have all the four external review categories. As the number of observation is very small for the bonds with all the four external review categories, I classify the observations into the same group if they have more than two types of external review categories. Thus, the total disclosure score can vary between 0 and 3 points. A higher disclosure score means higher level of disclosed information. Since it is costly to obtain an external review, it is likely that those bonds with an independent review might be compensated with a yield discount. Therefore, I expect a negative relationship between disclosure score and the yield spread. Similar to Equation (4.3), I estimate the ordinary least squares (OLS) model in Equation (4.4) to test whether the yield spread varies with the disclosure score.

$$
\widehat{p}_{i}=\alpha_{0}+\alpha_{1} \text { Disclosure Score }_{j}+\Sigma \alpha_{2} \text { Bond Characteristics }_{j}+\epsilon
$$

Columns (3) and (5) of Table 4.5 present the regression results for the full sample and the subsample of financial institutions, respectively. The baseline is when the bond is self-labeled (i.e., if the disclosure score is 0). In column (3), I find evidence that if the bond has one of the external review categories, on average, the yield spread is lower. Specifically, having one of the external review categories can reduce the yield spread by 44 basis points. This result is consistent with the conjecture that non-financial voluntary disclosure reduces information asymmetry between issuers and investors. Moreover, the yield spread is lower for larger issuances. Column (5) indicates that this effect is even higher for issuances in the financial industry. In particular, having one of the external review categories reduces the yield spread 83 basis points.

These results show that third-party verifications reduce the financing cost of some issuers because of the reduced information asymmetry. One limitation of my analysis is the potential presence of endogeneity due to omitted variable or selection bias as firms do 
not randomly issue green bonds. For this reason, it would be plausible to use an instrumental variable approach for issuance of green bonds. However, it is not straightforward to find such an instrument.

\subsubsection{Experienced Issuers}

Fatica, Panzica, and Rancan (2019) suggest that issuers placing more than one green bond are able to better signal their greenness over time. According to Kate Allen, "Threequarters of the capital raised in the market so far has gone to organizations that have sold greenlabeled debt more than once, according to data from rating agency Moody's. This suggests that it is only those borrowers who are comfortable with the amount of extra work involved in securing the green label that tend to become repeat issuers."(Financial Times, January 30, 2019). Therefore, I also consider repeated access to the green bond market by the same issuer as a way to provide more information to investors and guaranteeing against greenwashing. So I expect that if external review reduces asymmetric information between issuers and investors, the effect of non-financial disclosure on the yield spread should be less pronounced for the experienced issuers in the green bond market. Accordingly, I create an indicator variable, Experienced ${ }_{j}$, which is equal to one if the issuer is not issuing a green bond for the first time, and zero otherwise. In order to test whether the effect of non-financial disclosure is less pronounced for the experienced issuers, I estimate the ordinary least square (OLS) model in Equation (4.5).

$$
\begin{aligned}
\widehat{p}_{i}= & \alpha_{0}+\alpha_{1} \text { Experienced }_{j}+\alpha_{2} \text { Disclosure Score }_{j}+ \\
& \alpha_{3} \text { Experienced }_{j} \times \text { Disclosure Score }_{j}+\Sigma \alpha_{4} \text { Bond Characteristics }_{j}+\epsilon
\end{aligned}
$$

Table 4.6 presents the regression results of Equation (4.5). For the full sample, I find a negative impact of disclosure score on the yield spread in column (1), statistical significant at the $1 \%$ level. Having one of the external review categories reduces the yield spread, on average, 83 basis points. Moreover, if the issuer has issued green bonds more than once, the yield spread is lower (column (1), coefficient estimate of -0.425 , significant at the $5 \%$ level). Specifically, for the experienced issuers, the yield spread is, on average, 43 basis points lower. This implies that experienced issuers are able to better signal to the market their "greenness." As seen from the Table 4.6 column (1), the coefficient for the interaction term is positive and statistically significant at the $1 \%$ level when the issuer has one of the external review categories. Thus, access to the green bond market beforehand reduces the effect of disclosure. Specifically, for an experienced issuer, disclosure reduces the yield spread, on average, 27 basis points.

For the subsample of financials, the results are weakly significant. The sum of the coefficients for 1.Disclosure Score and 1.Disclosure Score\#1.Experienced is significantly different from zero at the $5 \%$ level, and implies that issuing green bond repeatedly reduces the effect of non-financial voluntary disclosure for the financial issuers, too. 


\subsubsection{Additional Tests}

In untabulated results, I repeat the pricing analysis and run the regression in Equation (4.2) for the subsample of green bonds with third-party verifications and conventional bonds. The results do not change and the yield spread is on average zero.

I also examine the effect of non-financial disclosure on the yield spread by carrying out a linear regression on the matched bond-day panel. In addition to the independent variables in Table 4.5, I also add the ask yield of the green bonds to control for the yield level. Further, I correct the standard errors by clustering at the issuer level as the residuals might be correlated in an OLS regression for panel data (Petersen, 2009). The results of this test are similar to those reported in Table 4.5 and are presented in Table 4.7. The specification in column (1) only includes the traditional bond pricing variables and the ask yield of the green bonds. A higher ask yield is positively related to the yield spread. In column (2), the coefficients of Disclosure Score remain statistically significant. In terms of magnitude, the effect is smaller ( 34 basis points) relative to those reported in Table 4.5. The coefficients in column (3) are also consistent with the previous results and suggest that the effect of non-financial disclosure is less pronounced for experienced issuers.

\subsection{Conclusion}

The green bond market has been growing in recent years. This chapter builds on existing research that provides mixed results on green bond pricing. In this study, I investigate whether there are pricing differences between green bonds and counterpart conventional bonds. I find that, on average, there is no significant premium for green bonds relative to conventional bonds, and the yield of a green bond is economically identical to that of a conventional bond. In addition, I analyze whether third-party verifications affect the yield spread between green bonds and conventional bonds. The results show that the yield spread is significantly reduced if a green bond has a third-party verification. This evidence mainly suggests that investors value external review, thus some issuers enjoy a lower financing costs. Moreover, these results indicate that the effect of disclosure is less pronounced for experienced issuers.

The results of this study have several policy implications. There is a common concern about the potential credibility of self-labeling because of greenwashing risk. The European Union is already keen to regulate the green bond market. The Commission published an Action Plan on Financing Sustainable Growth (European Commission, 2018) in 2018 and it is accompanied by "creating standards and labels for green financial products," among other actions. Moreover, given that the green bond market will continue to grow, there is an increasing interest from central banks and policy makers in sustainable investing and green finance. Thus, self-labeling might not be sufficient and powerful 
76 Chapter 4. The Effect of Voluntary Non-Financial Disclosure on Green Bond Pricing

enough, and creating standards might be necessary to establish investor confidence and to overcome the barriers that prevent the growth of the market. 


\section{Figures and Tables}

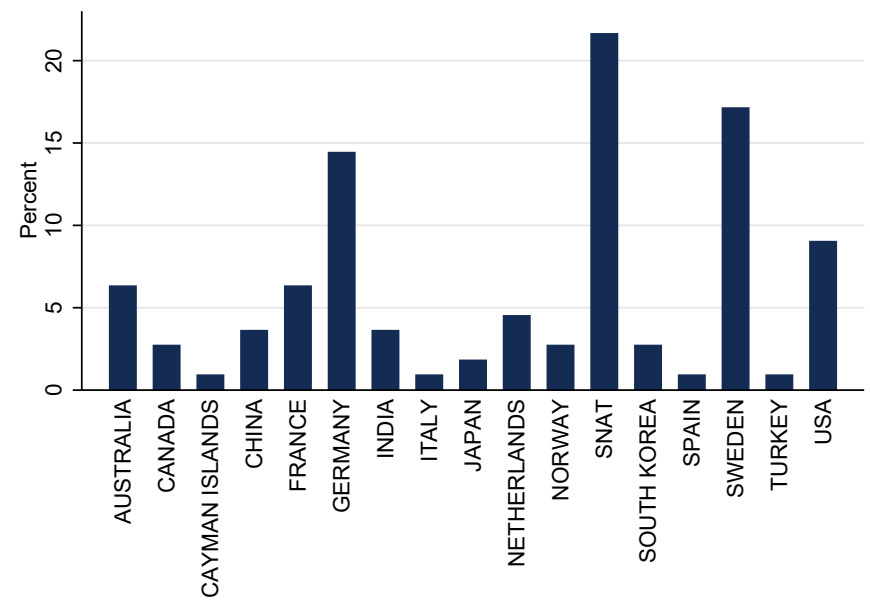

FIGURE 4.1: Green Bonds by Country.

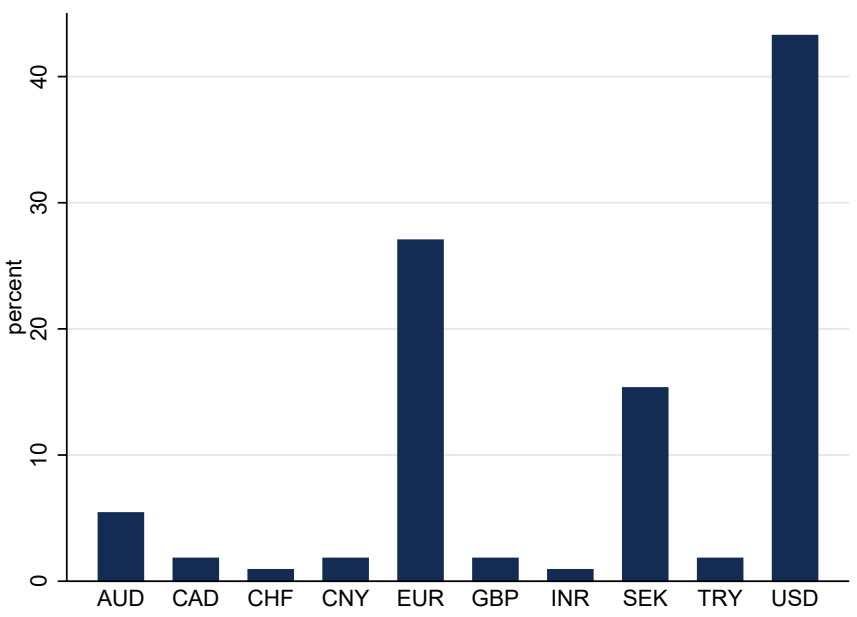

FIGURE 4.2: Green Bonds by Currency. 
78 Chapter 4. The Effect of Voluntary Non-Financial Disclosure on Green Bond Pricing

Table 4.1: Summary Statistics

Notes: This table reports the summary statistics for 111 pairs of bonds in the sample. All variables are defined in the Appendix C.

\begin{tabular}{lrrrrrrr}
\hline Variable & Mean & SD & P10 & P25 & P50 & P75 & P90 \\
\hline Ask Yield of the GB (\%) & 1.73 & 2.14 & -0.09 & 0.40 & 1.41 & 2.56 & 3.35 \\
Ask Yield of the CB (\%) & 1.69 & 2.15 & -0.12 & 0.38 & 1.38 & 2.50 & 3.27 \\
Difference in Yield (\%) & 0.04 & 0.50 & -0.27 & -0.09 & 0.02 & 0.14 & 0.38 \\
Coupon GB (\%) & 1.74 & 1.30 & 0.38 & 0.75 & 1.50 & 2.38 & 3.10 \\
Coupon CB (\%) & 1.78 & 1.32 & 0.38 & 0.75 & 1.56 & 2.50 & 3.25 \\
Maturity GB (years) & 6.02 & 3.44 & 3.00 & 4.02 & 5.01 & 7.01 & 10.01 \\
Maturity CB (years) & 6.02 & 3.64 & 3.00 & 4.00 & 5.02 & 7.02 & 10.02 \\
Issue Amount GB (USD mn) & 625.37 & 587.00 & 106.20 & 300.00 & 500.00 & 750.00 & $1,177.34$ \\
Issue Amount CB (USD mn) & $1,034.12$ & $1,128.58$ & 131.37 & 350.00 & 750.00 & $1,123.92$ & $2,250.00$ \\
Number of Days Per Bond & 385.97 & 184.79 & 193.00 & 227.00 & 373.00 & 561.00 & 654.00 \\
\hline
\end{tabular}


Table 4.2: Green Bonds versus Conventional Bonds

Notes: This table reports the results of paired two sided t-test and Wilcoxon matched-pairs signed-rank test.

\begin{tabular}{lrr}
\hline Yields & & \\
\hline & Paired two sided t-test & Wilcoxon signed-rank test \\
\hline Green & 1.725 & 1.408 \\
Conventional & 1.686 & 1.378 \\
Difference & 0.038 & 0.030 \\
t/z statistics & 16.114 & 25.247 \\
p-value & 0.0000 & 0.0000 \\
N & 42,843 & 42,843 \\
\hline
\end{tabular}


Table 4.3: Fixed-Effects Model

Notes: This table reports the regression result of Equation (4.2): $\Delta y_{i, t}=p_{i}+$ $\alpha_{0} \Delta$ Liquidity $_{i, t}+\epsilon_{i, t}$. The average number of observations per bond is 386 days. Standard errors are clustered at the issuer level and reported in the parenthesis. ${ }^{* * *}, * *$, and ${ }^{*}$ denote significance at the $1 \%, 5 \%$, and $10 \%$ level, respectively.

\begin{tabular}{lr}
\hline & $\Delta y_{i, t}$ \\
\hline$\Delta$ Liquidity & $0.331^{* * *}$ \\
& $(0.100)$ \\
$\mathrm{p}$ & -0.0173 \\
& $(0.017)$ \\
\hline Adjusted R & 0.008 \\
$\mathrm{~N}$ & 42,843 \\
Number of Bond Pairs & 111 \\
\hline
\end{tabular}


Table 4.4: Distribution of the Estimated Green Bond Premium

Notes: This table reports the distribution of the estimated green bond premium. $\hat{p}_{i}(\%)$ is calculated from $\Delta y_{i, t}=p_{i}+\alpha_{0} \Delta$ Liquidity $_{i, t}+\epsilon_{i, t}$.

\begin{tabular}{rrrrrr}
\hline$\hat{p}_{i}(\%)$ & & & & & \\
\hline Min. & P25 & Median & Mean & P75 & Max. \\
\hline-0.998 & -0.115 & -0.007 & -0.000 & 0.110 & 0.624 \\
\hline
\end{tabular}


Table 4.5: The Effect of Disclosure

Notes: This table reports the regression results of Equations (4.3) and (4.4) in which the yield spread is explained by the third-party verification. The dependent variable is the green bond premium. Verification is equal to one if the issuer obtains a post-issuance review by a third party, and zero otherwise. Disclosure Score includes four disclosure categories: second-party opinion, verification, rating and certification. The baseline rating category is AAA. All the variables are defined in the Appendix C. Standard errors are clustered at the issuer level. ${ }^{* * *},{ }^{* *}$, and ${ }^{*}$ denote significance at the $1 \%, 5 \%$, and $10 \%$ level, respectively.

\begin{tabular}{lccccc}
\hline & $(1)$ & $(2)$ & $(3)$ & $(4)$ & $(5)$ \\
& Full Sample & Full Sample & Full Sample & Financials & Financials \\
\hline & & & & & \\
Verification & & -0.140 & & -0.443 & \\
Disclosure Score $=1$ & & $(0.097)$ & & $(0.274)$ & \\
& & & $-0.442^{* *}$ & & $-0.828^{* * *}$ \\
Disclosure Score $=2$ & & & $(0.197)$ & & $(0.277)$ \\
& & & -0.322 & & $-0.551^{*}$ \\
Disclosure Score $=3$ & & & $(0.207)$ & & $(0.286)$ \\
& & & $-0.360^{*}$ & & $-0.580^{* * *}$ \\
AA & & & $(0.207)$ & & $(0.210)$ \\
& -0.083 & -0.063 & -0.114 & -0.456 & -0.109 \\
A & $(0.083)$ & $(0.086)$ & $(0.091)$ & $(0.405)$ & $(0.396)$ \\
& -0.051 & -0.047 & -0.087 & -0.124 & 0.028 \\
BBB & $(0.138)$ & $(0.140)$ & $(0.126)$ & $(0.184)$ & $(0.213)$ \\
& 0.144 & 0.171 & 0.112 & $0.191^{* * *}$ & $0.193^{* * *}$ \\
Nonrated & $(0.147)$ & $(0.139)$ & $(0.140)$ & $(0.006)$ & $(0.006)$ \\
& 0.041 & 0.160 & 0.093 & 0.414 & 0.332 \\
Ln(Issue Amount GB) & $(0.110)$ & $(0.153)$ & $(0.119)$ & $(0.326)$ & $(0.198)$ \\
& -0.047 & -0.034 & $-0.087^{* * *}$ & -0.101 & -0.147 \\
Maturity $\geq 5$ & $(0.043)$ & $(0.047)$ & $(0.032)$ & $(0.121)$ & $(0.120)$ \\
& 0.107 & 0.107 & 0.133 & 0.182 & $0.353^{* *}$ \\
Constant & $(0.090)$ & $(0.090)$ & $(0.085)$ & $(0.175)$ & $(0.139)$ \\
& 0.045 & 0.121 & 0.143 & 1.463 & $1.432^{*}$ \\
& $(0.324)$ & $(0.316)$ & $(0.242)$ & $(1.001)$ & $(0.792)$ \\
\hline Industry FE & & & & & \\
Country FE & Yes & Yes & Yes & Yes & Yes \\
Currency FE & Yes & Yes & Yes & Yes & Yes \\
\hline Observations & Yes & Yes & Yes & Yes & Yes \\
Adjusted $R^{2}$ & 111 & 111 & 111 & 45 & 45 \\
\hline & 0.085 & 0.104 & 0.143 & 0.087 & 0.333 \\
\hline & & & & & \\
& & & & &
\end{tabular}


Table 4.6: Experienced Issuers

Notes: This table reports the regression results of Equation (4.5). The dependent variable is the yield spread. Experienced is equal to one if the issuer is not issuing green bond for the first time, and zero otherwise. Disclosure Score includes four disclosure categories: second-party opinion, verification, rating and certification. The baseline rating category is AAA. All the variables are defined in the Appendix C. Standard errors are clustered at the issuer level. ${ }^{* * *},{ }^{* *}$, and ${ }^{*}$ denote significance at the $1 \%, 5 \%$, and $10 \%$ level, respectively.

(1) (2)

Full Sample Financials

Disclosure Score $=1$

$-0.830^{* * *} \quad-1.099^{* * *}$

Disclosure Score $=2$

$(0.158)$

$(0.263)$

$-0.691^{* * *}$

$-0.742^{* *}$

(0.178)

(0.308)

Disclosure Score $=3$

$-0.655^{* * *}$

$-0.796^{* * *}$

(0.142)

$(0.213)$

Experienced $=1$

$-0.425^{* *}$

$-0.302^{*}$

(0.174)

$(0.159)$

$0.559^{* * *}$

$0.444^{*}$

(0.201)

$(0.261)$

$0.469^{*}$

0.221

$(0.239)$

(0.268)

3.Disclosure Score\#1.Experienced

0.264

(0.218)

Ln(Issue Amount GB)

$-0.076^{* *}$

$-0.093$

$(0.035)$

(0.136)

AA

$-0.034$

0.025

$(0.098)$

$(0.463)$

A

$-0.044$

0.054

(0.140)

(0.258)

BBB

0.194

$0.261^{* *}$

(0.156)

(0.097)

0.090

0.328

(0.152)

$(0.207)$

0.127

$0.363^{* *}$

(0.098)

(0.149)

Constant

0.018

1.182

(0.272)

(0.916)

\begin{tabular}{lcc}
\hline Industry FE & Yes & No \\
Country FE & Yes & Yes \\
Currency FE & Yes & Yes \\
\hline Observations & 111 & 45 \\
Adjusted $R^{2}$ & 0.143 & 0.285 \\
\hline
\end{tabular}


Table 4.7: Robustness Test

Notes: This table reports the regression results of Equations (4.3), (4.4) and (4.5) on the matched bondday panel. The dependent variable is the yield spread. Verification is equal to one if the issuer obtains a post-issuance review by a third party, and zero otherwise. Disclosure Score includes four disclosure categories: second-party opinion, verification, rating and certification. The baseline rating category is AAA. All the variables are defined in the Appendix C. Standard errors are clustered at the issuer level. ${ }^{* * *}, * *$, and $*$ denote significance at the $1 \%, 5 \%$, and $10 \%$ level, respectively.

(1) (2) (3)

Full Sample Full Sample Full Sample

Verification

Disclosure Score $=1$

Disclosure Score $=2$

Disclosure Score $=3$

Experienced $=1$

1.Disclosure Score\#1.Experienced

2.Disclosure Score\#1.Experienced

3.Disclosure Score\#1.Experienced

\begin{tabular}{lccc} 
AA & $-0.103^{*}$ & $-0.187^{* *}$ & $-0.119^{*}$ \\
A & $(0.052)$ & $(0.071)$ & $(0.070)$ \\
& -0.115 & $-0.226^{* *}$ & $-0.201^{* *}$ \\
BBB & $(0.097)$ & $(0.095)$ & $(0.100)$ \\
& $0.180^{*}$ & 0.046 & 0.086 \\
Nonrated & $(0.106)$ & $(0.108)$ & $(0.115)$ \\
& 0.004 & -0.129 & -0.145 \\
Ln(Issue Amount GB) & $(0.108)$ & $(0.081)$ & $(0.102)$ \\
& 0.005 & -0.093 & -0.084 \\
Maturity $\geq 5$ & $(0.052)$ & $(0.057)$ & $(0.063)$ \\
& 0.031 & 0.051 & 0.050 \\
Ask Yield & $(0.067)$ & $(0.061)$ & $(0.071)$ \\
& $0.035^{*}$ & 0.026 & 0.025 \\
Constant & $(0.019)$ & $(0.017)$ & $(0.016)$ \\
& -0.114 & 0.283 & 0.177 \\
\hline Industry FE & $(0.335)$ & $(0.357)$ & $(0.373)$ \\
Country FE & Yes & Yes & Yes \\
Currency FE & Yes & Yes & Yes \\
\hline Observations & Yes & Yes & Yes \\
Adjusted $R^{2}$ & 42,843 & 42,843 & 42,843 \\
\hline
\end{tabular}

$-0.154^{* *}$

(0.066)

$-0.342^{* * *}$

$-0.823^{* * *}$

(0.124)

(0.109)

$-0.253^{* *}$

$-0.695^{* * *}$

(0.120)

(0.117)

$-0.227^{*}$

$-0.618^{* * *}$

(0.121)

(0.096)

$-0.450^{* * *}$

(0.110)

$0.563^{* * *}$

(0.137)

$0.472^{* * *}$

(0.138)

$0.286^{*}$

(0.160)

$-0.119^{*}$

$(0.100)$

0.086

$0.115)$

$-0.145$

(0.102)

$-0.084$

$(0.063)$

0.050

$0.016)$

0.177

$-0.114$

0.283

(0.373) 


\section{Appendix C}

\section{Variables and Credit Ratings}

Table C1: Variable Definitions

\begin{tabular}{|c|c|}
\hline Variable & Definition \\
\hline Currency & Indicator variables based on the currency of the bonds. \\
\hline Disclosure Score & $\begin{array}{l}\text { Indicator variables for an issuer's disclosure score and are equal to } 0,1,2 \\
\text { or } 3 \text {. }\end{array}$ \\
\hline Verification & $\begin{array}{l}\text { An indicator variable and is equal to one if the issuer obtains a post- } \\
\text { issuance review by a third party, and zero otherwise. }\end{array}$ \\
\hline Industry & $\begin{array}{l}\text { Indicator variables based on the sector: consumer discretionary, finan- } \\
\text { cials, government, industrials, technology and utilities. }\end{array}$ \\
\hline$\Delta$ Liquidity & $\begin{array}{l}\text { The difference between the liquidity of a green bond and its paired con- } \\
\text { ventional bond. }\end{array}$ \\
\hline Ln(Issue Amount GB) & $\begin{array}{l}\text { The natural logarithm of the par value of an initially issued bond, in } \\
\text { millions of dollars. }\end{array}$ \\
\hline Maturity & Indicator variables based on the maturity of the bond: $5 y<$ and $5 y \geq$. \\
\hline Rating & Indicator variables for rating categories based on the Table $\mathrm{C} 1$. \\
\hline$\Delta y_{i, t}$ & $\begin{array}{l}\text { The difference between the ask yield of a green bond and its paired } \\
\text { conventional bond. }\end{array}$ \\
\hline
\end{tabular}


Table C2: Credit Ratings

Notes: This table reports the scale comparison between the different ratings. "Rating Class" is a common scale for the ratings from Moody's and S\&P.

\begin{tabular}{llcr}
\hline S\&P Rating & Moody's Rating & Rating Class & Rating Grade \\
\hline AAA & Aaa & 1 & Investment grade \\
AA+ & Aa1 & 2 & Investment grade \\
AA & Aa2 & 2 & Investment grade \\
AA- & Aa3 & 2 & Investment grade \\
A+ & A1 & 3 & Investment grade \\
A & A2 & 3 & Investment grade \\
A- & A3 & 3 & Investment grade \\
BBB+ & Baa1 & 4 & Investment grade \\
BBB & Baa2 & 4 & Investment grade \\
BBB- & Baa3 & 4 & Investment grade \\
BB- & Ba3 & 4 & Speculative grade \\
NR & NR & 5 & Speculative grade \\
\hline
\end{tabular}




\section{Chapter 5}

\section{Conclusion}

This dissertation brings together three empirical projects on debt pricing. Chapters 2 and 3 provide insightful evidence on specific loan markets, in particular for real estate investors and for R\&D-intensive borrowers. Chapters 3 and 4 illustrate how firms overcome information asymmetry problems via signaling in private and public debt markets, respectively. The first project investigates the effect of information asymmetry on loans granted by banks and non-bank lenders in the CMBS market. The second project examines the effect of innovation disclosure on innovative firms' cost of debt. The third project asks the question of whether there are pricing differences between green bonds and conventional bonds, and analyze the impact of voluntary non-financial disclosure on the pricing of green bonds. Taken as a whole, the chapters of this dissertation share the interest to explore the effect of information asymmetry on the cost of debt capital in different markets. In the remainder of this chapter, I summarize the main empirical findings of each of the three projects.

In CHAPTER 2, I investigate whether the geographical distance is reflected in the CMBS loan pricing. The main contribution of this paper is to investigate how different types of lenders, specifically banks and non-bank lenders, price loans in the presence of informational frictions associated with geographical distance. I document that there is a positive relationship between distance and loan spread for mortgages originated by banks. Conversely, I do not find any effect for non-bank lenders. In addition, I perform a default analysis. The result shows that the distance between originator and borrower increases default probability for loans originated by both banks and non-bank lenders. This result supports the conclusion that access to soft information is a predictor of loan performance, but it is only priced by banks, and not by non-bank lenders. However, despite the documented differences in pricing by banks and non-banks, understanding how they differ in their ability to deal with information scarcity requires additional research.

CHAPTER 3 examines the impact of innovation disclosure through patenting on firms' cost of debt using the implementation of the American Inventors Protection Act (AIPA) as a natural experiment. In the pre-AIPA period, patents became public only after they were granted. However, in the post-AIPA period, firms are required to disclose information, 
even if the patent is not granted yet. I show that innovation disclosure through patenting activity only has a significant effect on the cost of debt in the post-AIPA period. The analysis of this chapter suggests that post-AIPA firms have an incentive to apply only for those patents about which they are relatively certain that they will result in a commercial success; otherwise, the details of their R\&D activities and strategic information would be revealed to the market.

In contrast to Chapter 2 and 3, CHAPTER 4 focuses on public debt, namely the bond market. The aim of this third project is to analyze whether there are pricing differences between green bonds and conventional bonds. Moreover, it addresses the signaling and investor preferences channels of voluntary non-financial disclosure on reducing cost of debt in the green bond market. The analysis shows that, on average, there is no significant premium for green bonds relative to conventional bonds, and the yield of a green bond is economically identical to that of a conventional bond. Furthermore, the yield spread is significantly reduced if a green bond has a third-party verification. This evidence mainly suggests that investors value external review, thus some issuers enjoy lower financing costs. Therefore, this chapter contributes to the nascent literature on green bonds.

Going forward, there are many promising avenues for further research. Chapter 2 studies non-bank lending (or shadow banking). With the rise of securitization, and especially after the crisis of 2008, new regulations are implemented in order to incentivize loan underwriters in the commercial real estate market. One future direction is to test the loan originators' pricing behavior and loan performance after the new regulation on risk retention rule. Findings from this research should also be considerable interest to policy makers and regulators. Chapter 3 explores the financing innovative firms. There is much more to build on the intersection of finance and innovation and their impact on society. Chapter 4 provides first evidence in detail on the voluntary non-financial disclosure in the green bond market. As the green bond market is a niche market, and new regulations are on the way, there is a tremendous potential for new research. New regulations will possibly permit new experimental settings in terms of methodology and will help to solve methodological limitations in the concurrent research. Moreover, given the novelty of the market, current research is based on a relatively small number of observations. As the green bond market grows and more data become available, future research should provide some further insights. 


\section{Chapter 6}

\section{Research Impact}

Sustainable economic growth depends on the well-functioning of financial markets. The 2008 financial crisis highlighted the weakness of the deregulated financial system. In the aftermath of the financial crisis, new regulations have been implemented by regulators and policy makers. The necessity to understand financial markets better makes academic research highly relevant for policy makers. Thereby, the results of the projects in this dissertation provide relevant empirical evidence for policy makers and regulators in order to support their decision-making process and for establishing trust and transparency in financial markets.

This dissertation contributes to the asymmetric information literature by exploring the information problems that firms face in debt markets. First, in a broad sense, this dissertation highlights the problem of scarcity or lack of information regarding borrowers. Chapter 2 of this dissertation contributes to the understanding of bank versus non-bank lending in the CMBS market. The findings of this project shed light on loan pricing practices of different types of lenders, and provide evidence that risk considerations are not the same across lenders. The results highlight the importance of soft information since it still plays a role for banks' pricing. Thus, it is critical to incentivize loan originators to invest in soft information to maintain credit quality as loosening underwriting standards poses risks to financial stability. However, while our understanding of bank lending has grown considerably over the last couple of decades, there is a need for more research in non-bank lending.

Second, the results of this dissertation highlight the role of signaling to access capital markets for informationally opaque firms. In particular, Chapters 3 and 4 illustrate signaling mechanism to overcome information asymmetry problems in debt markets. Innovative firms are inherently opaque as they prefer avoiding information leakages to competitors, however patent disclosure and the associated signaling value facilitates their access to the loan market. Chapter 3 emphasizes that innovation disclosure through patenting activity has a significant effect on the cost of debt. Chapter 4 illustrates the signaling channel of voluntary non-financial disclosure in the green bond market. This chapter shows that investors value external review regarding the "greenness" of a bond. 
Therefore, one of the implication of this project is that firms that are aware of the effect of third-party verification should be able to lower their financing cost.

In addition, Chapter 4 adds to the "green" debate. The high demand from investors reflects the transition towards a low-carbon economy. The green bond market has grown significantly in recent years but is still a niche market. Moreover, the emerging green bond market faces some barriers to its further growth such as a lack of standards and definitions. Policymakers need to focus on overcoming these barriers to maintain the growth of the market. For example, creating standards and disclosure might be necessary to establish investor confidence and transparency. Hence, the results of this project support to the initiatives of the European Union, which is already keen to regulate the green bond market and published the Action Plan on Financing Sustainable Growth (European Commission, 2018) in 2018.

Altogether, the results of this dissertation present a close link between academic research and policy debates, and provide relevant empirical evidence for policy makers in order them to improve trust and transparency in the financial markets. In the context of this dissertation, it can be achieved by implementing policies for incentivising financial institutions and creating standards for a better functioning of financial markets. 


\section{References}

Adams, C.A. and R. Evans (2004). "Accountability, Completeness, Credibility and the Audit Expectations Gap." In: Journal of Corporate Citizenship, 14, pp. 97-115.

Agarwal, S. and R. Hauswald (2010). "Distance and Private Information in Lending." In: Review of Financial Studies, 23 (7), pp. 2757-2788.

Agarwal, S., T.F. Sing, and L. Wang (2018). "Information Asymmetries and Learning in Commercial Real Estate Markets." In: Working Paper.

Albertazzi, U. et al. (2015). "Asymmetric Information in Securitization: An Empirical Assessment." In: Journal of Monetary Economics, 71 (C), pp. 33-49.

Alessandrini, P., M. Fratianni, and A. Zazzaro (2009). The Changing Geography of Banking and Finance. New York: Springer.

Almazan, A. (2002). "A Model of Competition in Banking: Bank Capital vs. Expertise." In: Journal of Financial Intermediation, 11 (1), pp. 87-121.

Altman, E.I. (1968). "Financial Ratios, Discriminant Analysis and the Prediction of Corporate Bankruptcy." In: Journal of Finance, 23, pp. 589-609.

- (2000). "Predicting Financial Distress of Companies: Revisiting the Z-Score and Zeta Models." In: Working Paper. Stern School of Business, New York University.

Ambrose, B. W. and A. B. Sanders (2003). "Commercial Mortgage-Backed Securities: Prepayment and Default." In: Journal of Real Estate Finance and Economics, 26 (2-3), pp. 179 196.

An, X. (2007). "Macroeconomic Conditions, Systematic Risk Factors, and the Time Series Dynamics of Commercial Mortgage Credit Risk." In: Working Paper.

An, X., Y. Deng, and S.A. Gabriel (2009). "Value Creation through Securitization: Evidence from the CMBS Market." In: Journal of Real Estate Finance and Economics, 38, pp. 302-326.

- (2011). "Asymmetric Information, Adverse Selection, and the Pricing of CMBS." In: Journal of Financial Economics, 100 (2), pp. 304-325.

Archer, W. R. et al. (2002). “Determinants of Multifamily Mortgage Deafult.” In: Real Estate Economics, 30 (3), pp. 445-473.

Atanassov, J. (2002). “Do Hostile Takeovers Stifle Innovation? Evidence from Antitakeover Legislation and Corporate Patenting." In: Journal of Finance, 68 (3), pp. 1097-1131.

Bachelet, M.J., L. Becchetti, and S. Manfredonia (2019). "The Green Bonds Premium Puzzle: The Role of Issuer Characteristics and Third-Party Verification". In: Sustainability 11 (4). 1098. 
Baghai, R. P. and B. Becker (2018). "Reputation and Competition in the Credit Ratings Market-Evidence from Commercial Mortgage-Backed Securities." In: Journal of Financial Economics, 135 (2), pp. 425-444.

Baker, M. et al. (2018). "Financing the Response to Climate Change: The Pricing and Ownership of U.S. Green Bonds." In: Working Paper.

Bao, J., J. Pan, and Wang J. (2011). "The Illiquidity of Corporate Bonds." In: Journal of Finance, 66 (3), pp. 911-946.

Barr, J. (2010). "Skyscrapers and the Skyline: Manhattan, 1895-2004." In: Real Estate Economics, 38 (3), pp. 567-597.

Bauer, R., K. Koedijk, and R. Otten (2005). "International Evidence on Ethical Mutual Fund Performance and Investment Style." In: Journal of Banking and Finance, 29 (7), pp. 1751-1767.

Bellucci, A., A. Borisov, and A. Zazzaro (2013). "Do Banks Price Discriminate Spatially? Evidence from Small Business Lending in Local Credit Markets." In: Journal of Banking and Finance, 37 (11), pp. 4183-4197.

Bhattacharya, S. and J.R. Ritter (1983). "Innovation and Communication: Signalling with Partial Disclosure." In: Review of Economic Studies, 50 (2), pp. 331-346.

Bilmes, L., C. DuPont, and J.N. Levitt (2015). "Green Bonds and Land Conservation: The Evolution of a New Financing Tool." In: Working Paper.

Black, L.K. et al. (2012). "Differences Across Originators in CMBS Loan Underwriting." In: Journal of Financial Services Research, 42 (1), pp. 115-134.

Campbell, D., P. Shrives, and H.B. Saager (2001). "Voluntary Disclosure of Mission Statements in Corporate Annual Reports: Signaling What and to Whom?" In: Business and Society Review, 106 (1), pp. 65-87.

Campbell, T.S. (1979). “Optimal Investment Financing Decisions and The Value of Confidentiality." In: Journal of Financial and Quantitative Analysis, 14 (5), pp. 913-924.

Campbell, T.S. and W.A. Kracaw (1980). "Information Production, Market Signalling and the Theory of Financial Intermediation." In: Journal of Finance, 35 (4), pp. 863-883.

Carey, M., M. Post, and S.A. Sharpe (1998). "Does Corporate Lending by Banks and Finance Companies Differ? Evidence on Specialization in Private Debt Contracting." In: Journal of Finance, 53 (3), pp. 845-878.

Casey, R.J. and J.H. Grenier (2015). "Understanding and Contributing to the Enigma of Corporate Social Responsibility (CSR) Assurance in the United States." In: Auditing: A Journal of Practice and Theory, 34 (1), pp. 97-130.

Chau, G. and S.J. Gray (2010). "Family Ownership, Board Independence and Voluntary Disclosure: Evidence from Hong Kong." In: Journal of International Accounting, Auditing and Taxation, 19, pp. 93-109.

Chava, S. (2014). "Environmental Externalities and Cost of Capital." In: Management Science, 60 (9), pp. 2223-2247.

Chen, L., D.A. Lesmond, and J. Wei (2007). "Corporate Yield Spreads and Bond Liquidity." In: Journal of Finance, 62 (1), pp. 119-149. 
Chernenko, S., I. Erel, and R. Prilmeier (2019). "Nonbank Lending." In: Working Paper.

Ciochetti, B. A. et al. (2002). "The Termination of Commercial Mortgage Contracts through Prepayment and Default: A Proportional Hazard Approach with Competing Risks." In: Real Estate Economics, 30 (4), pp. 595-633.

Clarkson, P.M. et al. (2013). "The Relevance of Environmental Disclosures: Are Such Disclosures Incrementally Informative?" In: Journal of Accounting and Public Policy, 32 (5), pp. 410-431.

Cochu, A. et al. (2016). Study on the Potential of Green Bond Finance for Resource-Efficient Investments. Europen Comission.

Conklin, J., M. Diop, and M. Qiu (2018). “How Do Firms Finance Nonprimary Market Investments? Evidence from REITs." In: Real Estate Economics, 46 (1), pp. 120-159.

Degryse, H. and S. Ongena (2005). "Distance, Lending Relationships, and Competition." In: Journal of Finance, 60 (1), pp. 231-266.

Denis, D.J. and V.T. Mihov (2003). "The Choice among Bank Debt, Non-bank Private Debt, and Public Debt: Evidence from New Corporate Borrowings." In: Journal of Financial Economics, 70 (1), pp. 3-28.

Dhaliwal, D. et al. (2011). "Voluntary Nonfinancial Disclosure and the Cost of Equity Capital: The Initiation of Corporate Social Responsibility Reporting." In: Accounting Review, 86 (1), pp. 59-100.

Diamond, D. and R. Rajan (2001). “Liquidity Risk, Liquidity Creation and Financial Fragility: A Theory of Banking." In: Journal of Political Economy, 109 (2), pp. 287-327.

Dick-Nielsen, J., P. Feldhutter, and D. Lando (2012). “Corporate Bond Liquidity Before and After the Onset of the Subprime Crisis." In: Journal of Financial Economics, 103 (3), pp. 471-492.

Dye, R.A. (1985). “Disclosure of Nonproprietary Information." In: Journal of Accounting Research, 23 (1), pp. 123-145.

Ehlers, T. and F. Packer (2017). “Green Bond Finance and Certification." In: BIS Quarterly Review, September.

Eichholtz, P., R. Holtermans, and E. Yonder (2016). "The Economic Effects of Owner Distance and Local Property Management in US Office Markets." In: Journal of Economic Geography, 16 (4), pp. 781-803.

El Ghoul, S. et al. (2011). "Does Corporate Social Responsibility Affect the Cost of Capital?" In: Journal of Banking and Finance, 35 (9), pp. 2388-2406.

European Commission (2018). Action Plan: Financing Sustainable Growth. Accessed March 2020, https : / / eur - lex . europa . eu / legal - content / EN / TXT / PDF / ?uri =CELEX : 52018DC0097\&from=EN.

Fama, Eugene F. (1985). “What's Different about Banks?" In: Journal of Monetary Economics, 15 (1), pp. 29-39.

Fatica, S., R. Panzica, and M. Rancan (2019). "The Pricing of Green Bonds: Are Financial Institutions Special?" In: JRC Working Papers in Economics and Finance. 
Financial Times (January 30, 2019). Disclosure is a Lure for Green Bond Investors. Accessed March 2020, https://www.ft. com/content/b70a098e-1f24-11e9-b126-46fc3ad87c65.

Flammer, C. (2018). “ Corporate Green Bonds.” In: Working Paper.

Francis, B. et al. (2012). "Do Banks Value Innovation? Evidence from US Firms." In: Financial Management, 41 (1), pp. 159-185.

Friewald, N., R. Jankowitsch, and M. Subrahmanyam (2012). "Illiquidity or Credit Deterioration: A Study of Liquidity in the US Corporate Bond Market During Financial Crises." In: Journal of Financial Economics, 105 (1), pp. 18-36.

Garmaise, M. J. and T. J. Moskowitz (2004). "Confronting Information Asymmetries: Evidence from Real Estate Markets." In: Review of Financial Studies, 17 (2), pp. 405-437.

Ge, W. and M. Liu (2015). "Corporate Social Responsibility and the Cost of Corporate Bonds." In: Journal of Accounting and Public Policy, 34, pp. 597-624.

Gehrig, T. (1998). "Screening, Cross-border Banking and the Allocation of Credit." In: Research in Economics, 52 (4), pp. 387-407.

Gianfrate, G. and M. Peri (2019). "The Green Advantage: Exploring the Convenience of Issuing Green Bonds." In: Journal of Cleaner Production, 219, pp. 127-135.

Giroud, Xavier. (2013). “Proximity and Investment: Evidence from Plant-level Data.” In: Quarterly Journal of Economics, 128 (2), pp. 861-915.

Graham, S. and D. Hegde (2015). “Disclosing Patents' Secrets.” In: Science, 347, pp. 236237.

Griliches, Z. (1990). “Patents Statistics as Economic Indicators: A Survey." In: Journal of Economic Literature, 28 (4), pp. 1661-1707.

Hachenberg, B. and D. Schiereck (2018). “Are Green Bonds Priced Differently from Conventional Bonds?" In: Journal of Asset Management, 19 (6), pp. 371-383.

Hall, B.H. (2010). “The Financing of Innovative Firms." In: Review of Economics and Institutions, 1, pp. 1-30.

Hall, B.H., A. Jaffe, and M. Trajtenberg (2001). "The NBER Patent and Citation Data File: Lessons, Insights, and Methodological Tools." In: NBER Working Paper No: 8498.

Hall, B.H. et al. (2014). "The Choice Between Formal and Informal Intellectual Property: A Review." In: Journal of Economic Literature, 52 (2), pp. 375-423.

Hartzmark, S.M. and A.B. Sussman (2019). "Do Investors Value Sustainability? A Natural Experiment Examining Ranking and Fund Flows?" In: Journal of Finance, 74 (6), pp. 2789-2837.

Helwege, J., J.Z. Huang, and Y. Wang (2014). "Liquidity Effects in Corporate Bond Spreads." In: Journal of Banking and Finance, 45, pp. 105-116.

Hollander, S. and A. Verriest (2016). "Bridging the Gap: the Design of Bank Loan Contracts and Distance." In: Journal of Financial Economics, 119 (2), pp. 399-419.

Hölmstrom, B. and J. Tirole (1997). "Financial Intermediation, Loanable Funds, and the Real Sector." In: Quarterly Journal of Economics, 112 (3), pp. 663-691.

Houweling, P., A. Mentink, and T. Vorst (2005). "Comparing Possible Proxies of Corporate Bond Liquidity." In: Journal of Banking and Finance, 29 (6), pp. 1331-1358. 
Hu, J., G. Li, and F. Zhu (2017). "Regional Financial Developments and Research and Development Investment-Cash Flow Sensitivity: Evidence on Chinese Public HighTech Companies." In: International Review of Finance, 17 (4), pp. 627-643.

ICMA (June 2018). Green Bond Principles, Voluntary Process Guidelines for Issuing Green Bonds.

James, Christopher (1987). "Some Evidence on the Uniqueness of Bank Loans." In: Journal of Financial Economics, 19 (2), pp. 217-235.

Johnson, S. A. (1997). "An Empirical Analysis of the Determinants of Corporate Debt Ownership Structure." In: Journal of Financial and Quantitative Analysis, 32 (1), pp. 4769.

Kale, J.R. and C. Meneghetti (2011). "The Choice Between Public and Private Debt: A Survey." In: IIMB Management Review, 23, pp. 5-14.

Karolyi, S.A. (2018). “Personal Lending Relationships.” In: Journal of Finance, 73 (1), pp. 549.

Karpf, A. and A. Mandel (2018). "The Changing Value of the "Green" Label on the US Municipal Bond Market." In: Nature Climate Change, 8 (2), pp. 161-168.

Kerr, W.R. and R. Nanda (2015). "Financing Innovation." In: Annual Review of Financial Economics, 7, pp. 445-462.

Keys, B.J. et al. (2010). “Did Securitization Lead to Lax Screening? Evidence from Subprime Loans." In: Quarterly Journal of Economics, 125 (1), pp. 307-362.

Khurana, I. and K. Raman (2003). "Are Fundamentals Priced in the Bond Market?" In: Contemporary Accounting Research, 20 (3), pp. 465-494.

Kinder, P.D. (2005). “Socially Responsible Investing: An Evolving Concept in a Changing World." In: Boston: KLD Research and Analytics 1-65.

Knyazeva, A. and D. Knyazeva (2012). “Does Being Your Bank's Neighbour Matter?” In: Journal of Banking and Finance, 36 (4), pp. 1194-1209.

Kreander, N. et al. (2005). "Evaluating the Performance of Ethical and Non-ethical funds: A Matched Pair Analysis." In: Journal of Business Finance and Accounting, 32 (7-8), pp. 1465-1493.

Kronovet, A. (1997). "An Overview of Commercial Mortgage Backed Securitization: The Devil is in the Details." In: North Carolina Banking Institute 1 (1), pp. 288-321.

Lambson, V. E., G. R. McQueen, and B. A. Slade (2004). “Do Out-of-States Borrowers Buyers Pay More for Real Estate? An Examination of Anchoring-Induced Bias and Search Costs." In: Real Estate Economics, 32 (1), pp. 85-126.

Larcker, D.F. and E.M. Watts (2020). "Where's the Greenium?" In: Journal of Accounting and Economics. 69 (2-3). 101312.

Leland, H. and D. Pyle (1977). "Information Asymmetries, Financial Structure, and Financial Intermediation." In: Journal of Finance, 32 (2), pp. 371-387.

Leuz, C. and R. E. Verrecchia (2000). "The Economic Consequences of Increased Disclosure." In: Journal of Accounting Research, 38, pp. 91-124. 
Lewis, M.K. (1992). “Modern Banking in Theory and Practice". In: Revue Économique, 43 (2), pp. 203-228.

Lin, Z.J., S. Liu, and F Sun (2017). "The Impact of Financing Constraints and Agency Costs on Corporate R\&D Investment: Evidence from China." In: International Review of Finance, 17 (1), pp. 3-42.

Ling, D. C., A. Naranjo, and M. T. Petrova (2018). "Search Costs, Behavioral Biases, and Information Intermediary Effects." In: Journal of Real Estate Finance and Economics, 57 (1), pp. 114-151.

Lummer, S. and J. McConnell (1989). "Further Evidence on the Bank Lending Process and the Capital Market Response to Bank Loan Agreements." In: Journal of Financial Economics, 25 (1), pp. 99-122.

Magnanelli, B.S. and M.F. Izzo (2017). "Corporate Social Performance and Cost of Debt: The Relationship." In: Social Responsibility Journal, 13 (2), pp. 250-265.

Mansfield, E. (1986). "Patents and Innovation: An Empirical Study." In: Management Science, 32 (2), pp. 173-181.

Martínez-Ferrero, J. and García-Sánchez (2017). "Sustainability Assurance and Cost of Capital: Does Assurance Impact on Credibility of Corporate Social Responsibility Information?" In: Business Ethics: A European Review, 26 (3), pp. 223-239.

Menz, K.M. (2010). “Corporate Social Responsibility: Is it Rewarded by the Corporate Bond Market? A Critical Note." In: Journal of Business Ethics, 96, pp. 117-134.

Milgrom, P. and N. Stokey (1982). "Information, Trade and Common Knowledge." In: Journal of Economic Theory, 26 (1), pp. 17-27.

Ng, T.H. and J.Y. Tao (2016). “Bond Financing for Renewable Energy in Asia.” In: Energy Policy, 95 (C), pp. 509-517.

Nilsson, J. (2009). "Segmenting Socially Responsible Mutual Fund Investors: The Influence of Financial Return and Social Responsibility." In: International Journal of Bank Marketing, 27 (1), pp. 5-31.

Oikonomou, I., C. Brooks, and S. Pavelin (2014). "The Effects of Corporate Social Performance on the Cost of Corporate Debt and Credit Ratings." In: Financial Review, 49 (1), pp. $49-75$.

Park, S.K. (2018). "Investors as Regulators: Green Bonds and the Governance Challenges of the Sustainable Finance Revolution." In: Stanford Journal of International Law, 54 (1), pp. 1-47.

Petersen, M. A. (2009). “Estimating Standard Errors in Finance Panel Data Sets: Comparing Approaches." In: Review of Financial Studies, 22 (1), pp. 435-480.

Petersen, M. A. and R. G. Rajan (2002). “Does Distance Still Matter? The Information Revolution in Small Business Lending." In: Journal of Finance, 57 (6), pp. 2533-2570.

Plumlee, M., D. Brown, and R.S. Marshall (2015). “Voluntary Environmental Disclosure Quality and Firm Value: Further Evidence." In: Journal of Accounting and Public Policy, 34 (4), pp. 336-361. 
Plumlee, M. et al. (2015). "Bank Loan Spread and Private Information: Pending Approval Patents." In: Review of Accounting Studies, 20, pp. 593-638.

Purnanandam, A. (2011). “Originate-to-Distribute Model and the Subprime Mortgage Crisis." In: Review of Financial Studies, 24 (6), pp. 1881-1915.

Rajan, U., A. Seru, and V. Vig (2015). "The Failure of Models that Predict Failure: Distance, Incentives and Defaults." In: Journal of Financial Economics, 115 (2), pp. 237-260.

Renneboog, L., J. Ter Horst, and C. Zhang (2008). "The Price of Ethics and Stakeholder Governance: The Performance of Socially Responsible Mutual Funds." In: Journal of Corporate Finance, 14 (3), pp. 302-322.

Richardson, A. and M. Welker (2001). "Social Disclosure, Financial Disclosure and the Cost of Equity Capital." In: Accounting, Organizations and Society, 26 (7-8), pp. 597616.

Riedl, A. and P. Smeets (2017). "Why Do Investors Hold Socially Responsible Mutual Funds?" In: Journal of Finance, 72 (6), pp. 2505-2550.

Sharfman, M.P. and C.S. Fernando (2008). “Environmental Risk Management and the Cost of Capital." In: Strategic Management Journal, 29 (6), pp. 569-592.

Simnett, R., A. Vanstraelen, and W.F. Chua (2009). "Assurance on Sustainability Reports: An International Comparison." In: Accounting Review, 84 (3), pp. 937-967.

Statman, M. (2000). "Socially Responsible Mutual Funds." In: Financial Analysts Journal, 56 (3), pp. 30-39.

Sussman, O. and J. Zeira (1995). “Banking and Development.” In: CEPR Discussion Paper, 1127.

Tang, D.Y. and Y. Zhang (2018). “Do Shareholders Benefit from Green Bonds?” In: Journal of Corporate Finance, 61. 101427.

Titman, S., S. Tompaidis, and S. Tsyplakov (2005). "Determinants of Credit Spreads in Commercial Mortgages." In: Real Estate Economics, 33 (4), pp. 711-738.

Titman, S. and S. Tsyplakov (2010). "Originator Performance, CMBS Structures, and the Risk of Commercial Mortgages." In: Review of Financial Studies, 23 (9), pp. 3558-3594.

Tolliver, C., A.R. Keeley, and S. Managi (2019). "Green Bonds for the Paris Agreement and Sustainable Development Goals." In: Environmental Research Letters, 14 (6).

- (2020). "Drivers of Green Bond Market Growth: The Importance of Nationally Determined Contributions to the Paris Agreement and Implications for Sustainability." In: Journal of Cleaner Production, 244. 118643.

Vandell, K. D. et al. (1993). “Commercial Mortgage Defaults: Proportional Hazards Estimation Using Individual Loan Histories." In: Real Estate Economics, 21 (4), pp. 451480.

Verrecchia, R.E. (1983). “Discretionary Disclosure." In: Journal of Accounting and Economics, 5 (3), pp. 179-194.

Wittenberg-Moerman, R. (2008). "The Role of Information Asymmetry and Financial Reporting Quality in Debt Trading: Evidence from the Secondary Loan Market." In: Journal of Accounting and Economics, 46 (2-3), pp. 240-260. 
Zerbib, O.D. (2019). “The Effect of Pro-Environmental Preferences on Bond Prices: Evidence from Green Bonds." In: Journal of Banking and Finance, 98, pp. 39-60. 


\section{Curriculum Vitae}

Nagihan Mimiroğlu was born on 13 October 1983 in Istanbul, Turkey. She studied Mathematics at Mimar Sinan University in Istanbul. After her graduation in 2005, Nagihan worked at Finansbank as a Supervisor and an Assistant Manager. In 2013, Nagihan attended Universidad Autónoma de Madrid as an exchange student. She obtained a M.Sc. in Financial Economics from the Istanbul Bilgi University in 2015, and a Master in Business and Quantitative Methods from Universidad Carlos III de Madrid in 2016.

In 2016, Nagihan joined the Department of Finance at Maastricht University as a Ph.D. candidate. She presented her papers related to this dissertation at international conferences and seminars at University of Bonn, ZEW Mannheim, Fordham University, KU Leuven and the Barcelona Graduate School of Economics.

In 2018, she attended University of Zurich as a visiting Ph.D. student hosted by Steven Ongena. In 2019, she also visited Fordham University hosted by Iftekhar Hasan and Copenhagen Business School hosted by Daniel Streitz.

Nagihan is going to join Lund University as a Postdoctoral Researcher in September 2020. 




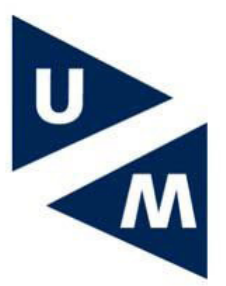

